Universidade de São Paulo

Faculdade de Educação

ROSEMARY SOFFNER

Avaliação da aprendizagem em curso a distância 


\section{ROSEMARY SOFFNER}

Avaliação da aprendizagem em curso a distância

Tese apresentada ao Programa de PósGraduação em Educação da Faculdade de Educação da Universidade de São Paulo, para a obtenção do título de doutor em educação.

Área de Pesquisa: Didática, teorias de ensino e Práticas escolares

Orientadora: Profa. Dra. Roseli C. Rocha de C. Baumel

São Paulo

2010 
Autorizo a reprodução e divulgação total ou parcial deste trabalho, por qualquer meio convencional ou eletrônico, para fins de estudo e pesquisa, desde que citada a fonte.

\section{Catalogação na Publicação \\ Serviço de Biblioteca e Documentação \\ Faculdade de Educação da Universidade de São Paulo}

371.295 Soffner, Rosemary

S681a Avaliação da aprendizagem em curso a distância / Rosemary Soffner ; orientação Roseli Cecília Rocha de Carvalho Baumel. São Paulo : s.n., 2010.

$107 \mathrm{p}$.

Tese (Doutorado - Programa de Pós-Graduação em Educação. Área de Concentração: Didática, Teorias de Ensino e Práticas Escolares) - Faculdade de Educação da Universidade de São Paulo.

1. Avaliação da aprendizagem 2. Educação à distância - História 3.

Legislação 4. Ensino superior I. Baumel, Roseli Cecília Rocha de Carvalho, orient. 
Rosemary Soffner

Avaliação da aprendizagem em curso a distância

Tese apresentada ao Programa de PósGraduação em Educação da Faculdade de Educação da Universidade de São Paulo, para a obtenção do título de doutor em educação.

Área de Pesquisa: Didática, teorias de ensino e Prática escolares

Aprovada em:

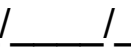

Presidente da banca: Profa ${ }^{a}$ Dra . Roseli Cecília Rocha de Carvalho Baumel Instituição: Faculdade de Educação da Universidade de São Paulo Assinatura:

Prof.Dr.

Banca examinadora:

Instituição:

Assinatura:

Prof.Dr.

Instituição:

Assinatura:

Prof.Dr.

Instituição:

Assinatura:

Prof.Dr.

Instituição:

Assinatura: 
Para os meus pais. 


\section{AGRADECIMENTOS}

À Prof ${ }^{a}$ Roseli Baumel, pela orientação, acolhimento, apoio, confiança e genuína amizade.

À Faculdade de Educação da USP, pela oportunidade de aprofundar minhas reflexões.

Aos amigos, pela paciência da escuta e diálogos enriquecedores.

A toda minha família pelo apoio que sempre deram às minhas escolhas. 
Já perdoei erros quase imperdoáveis, tentei substituir pessoas insubstituíveis e esquecer pessoas inesquecíveis. Já fiz coisas por impulso, já me decepcionei com pessoas quando nunca pensei me decepcionar, mas também decepcionei alguém. Já abracei pra proteger, já dei risada quando não podia, fiz amigos eternos, amei e fui amado, mas também já fui rejeitado, fui amado e não amei. Já gritei e pulei de tanta felicidade, vivi de amor e fiz juras eternas, "quebrei a cara" muitas vezes! Já chorei ouvindo música e vendo fotos, já liguei só pra escutar uma voz, me apaixonei por um sorriso, já pensei que fosse morrer de tanta saudade e... tive medo de perder alguém especial (e acabei perdendo)! Mas vivi! E ainda vivo! Não passo pela vida... e você também não deveria passar. Viva!!! Bom mesmo é ir a luta com determinação, abraçar a vida e viver com paixão, perder com classe e vencer com ousadia, porque o mundo pertence a quem se atreve e a vida é MUITO para ser insignificante. 


\section{RESUMO}

SOFFNER, Rosemary. Avaliação da aprendizagem em curso a distância. 2010. 107 f. Tese (doutorado em educação) - Faculdade de Educação, Universidade de São Paulo, São Paulo, 2010.

Esta tese estuda as concepções de avaliação da aprendizagem em cursos a distância, pois tendo em vista a crescente oferta de cursos nesta modalidade de ensino, a partir do desenvolvimento das tecnologias de informação e comunicação, acreditamos ser o tema relevante para que cursos a distância possam, de fato, contribuir, para que superemos, enquanto nação, a desigualdade de acesso à educação. Consideramos como aporte teórico os princípios da avaliação formativa, uma vez que um de seus principais objetivos é oferecer informações para que professor e aluno possam repensar e fazer os ajustes necessários nos processos de ensino e aprendizagem. $O$ estudo feito sobre a História da Educação a Distância e os meios de comunicação utilizados nesta modalidade de ensino objetivou compreender o status que ocupa nos dias de hoje, para então entender as prováveis concepções que norteiam a legislação vigente sobre o tema. Também analisamos três documentos de instituições de ensino superior que oferecem cursos a distância, buscando identificar a concepção de avaliação da aprendizagem. Como contribuição, podemos destacar dois pontos: a análise de instrumentos de avaliação da aprendizagem que podem ser utilizados em cursos a distância e um conjunto de princípios que podem gerar inúmeras práticas pedagógicas que favoreçam a construção do conhecimento e a aprendizagem. As críticas apontadas à legislação vigente objetivam criar espaços para debates produtivos que possam contribuir para a elaboração de um projeto nacional de educação.

Palavras-chave: Avaliação da Aprendizagem, Educação a Distância, Avaliação Formativa, Legislação para a Educação a Distância. 


\begin{abstract}
SOFFNER, Rosemary. Learning evalution in distance educacion. 2010. $107 f$. Tese (doutorado em educação) - Faculdade de Educação, Universidade de São Paulo, São Paulo, 2010.
\end{abstract}

This thesis studies conceptions of the learning valuation whenever long distance education courses are applied, since we have noticed the growing offering and supply of distance learning for education and training courses lately. Taking into account the development of information and communication technologies, we firmly believe that this subject is relevant in order that distance education courses may, as a matter of fact, contribute to overcome, as Nation, the great disparity of access to education we undergo. We have considered, as theoretical support, the principles of formative valuation, once one of its chief objectives is to offer reliable information so that the teacher and student are capable of rethinking and adjust whatever and wherever necessary the teaching and knowledge processes. The research and study done about the History of Distance Education as well as the means of communication employed by this path of teaching has aimed to understand the status in which it is placed presently, so that we may know and comprehend the probable conceptions which guide and direct the legislation in force about this theme. We have, also, analysed three dossier and records of college education institutions which offer long distance education and learning courses, attempting to identify the conception of learning gain valuation. As contibution, we were able to put in relief two aspects: the analysis of which instruments and tools of valuation may be used in long distance education courses, as well as a set of principles that might generate uncountable pedagogic practices which may enhance and benefit the knowledge and learning process construction. The review and criticism pointed to the legislation in force aim to create spaces and make room to productive debates which may contribute to the elaboration of a national education project.

Keywords: Learning Valuation, Distance Education, Formative Valuation, Distance Education Legislation, Distance Learning and Education Courses. 


\section{SUMÁRIO}

I. INTRODUÇÃO 1

II. MARCO TEÓRICO

1. Avaliação da Aprendizagem 5

2. Educação a Distância 25

3. Educação a Distância e os meios 39

III. MARCO METODOLÓGICO 55

IV. ANÁLISE E TRATAMENTO DOS DADOS 58

V. CONCLUSÕES

$\begin{array}{lr}\text { VI. BIBLIOGRAFIA } & 101\end{array}$

ANEXO

ENCARTE - CD-ROM 


\section{Introdução}

O tema "avaliação" tem estado presente, cada vez mais, na sociedade, de uma forma geral, assim como nas esferas educacionais. Mas nem sempre esse tema, ou termo, tem o mesmo sentido ou faz referência a um mesmo campo de ação.

Segundo o dicionário Houaiss da língua portuguesa, avaliação vem de avaliar + ação que é o ato ou efeito de avaliar. E, avaliar é estabelecer a valia ou valor de algo. Como verbo transitivo, ele necessita de um complemento. Portanto, se usarmos apenas "avaliação" damos margem a inúmeros entendimentos ou sentidos ao termo.

O ato de atribuir valor, ou a avaliação está presente no nosso cotidiano. Avaliamos sentimentos, ações, impressões, aparências etc. Por exemplo, avaliamos se estamos adequadamente vestidos para uma situação específica, avaliamos se gostamos de um filme e assim por diante. São atribuições de valores, diferentes das que fazemos na área educacional.

Mesmo quando falamos em avaliação educacional, é preciso definir quais aspectos estão sendo considerados. A avaliação educacional, em um sentido mais amplo, transcende os aspectos técnicos e permite estabelecer uma ponte entre os processos de âmbito pedagógico e os processos sociais e políticos ${ }^{1}$. Podemos avaliar: políticas públicas para a educação, currículos, cursos, sistemas educacionais, projetos e, inclusive aprendizagem.

Cada um dos itens mencionados é um campo extenso de pesquisa necessários para "o pensar" a Educação. No entanto, essa pesquisa objetiva trabalhar exclusivamente com a avaliação da aprendizagem.

\footnotetext{
${ }^{1}$ AFONSO, Almerindo J. Avaliação Educacional: regulação e emancipação. São Paulo: Cortez Editora, 2000.
} 
Professores e alunos, de uma forma geral, mostram-se insatisfeitos com esse aspecto da educação escolar. Muitas vezes ela é usada como instrumento de poder ou apenas como mera formalidade. Mas existem trabalhos que fazem da avaliação não apenas um momento pontual, mas um aspecto importante do processo educacional, que objetiva, entre outras coisas, repensar a organização curricular, propor novas estratégias de ensino etc., enfim, fazem da avaliação um instrumento que pode facilitar a aprendizagem.

Esse entendimento de avaliação, teoricamente, não é novo e não são poucos os autores que vêm publicando livros e pesquisas nessa área, mas curiosamente a maioria dos trabalhos considera como universo a educação na modalidade presencial.

Poucas são as produções sobre Avaliação da Aprendizagem que fazem referência à modalidade a distância. Esse tema aparece sim, quase que exclusivamente, na bibliografia relacionada à Educação a Distância ${ }^{2}$ propriamente dita. Mesmo assim não se percebe a relação entre as reflexões relativas à Educação a Distância e a grande produção sobre a Avaliação da Aprendizagem.

Por outro lado, a Educação a Distância, a cada dia, ganha mais espaço, inclusive com incentivos governamentais sob o propósito de que por meio dessa modalidade ${ }^{3}$

\footnotetext{
${ }^{2}$ Apesar de encontrarmos, às vezes, o uso da crase na expressão "Educação à Distância", entendemos que não deva ser grafada sem a crase, ou seja, Educação a Distância, uma vez que trata-se de uma tipo de educação e a distância não está determinada.

${ }^{3}$ Segundo o Prof. Francisco Aparecido Cordão, Conselheiro da Câmara de Educação Básica do Conselho Nacional de Educação, em artigo ainda não publicado,

Modalidade de Ensino é um conceito polissêmico que, na própria LDB - Lei de Diretrizes e Bases da Educação Nacional é utilizado com diferentes sentidos. Encontramos o termo modalidade de ensino associado aos diferentes níveis de ensino ou identificando metodologias diversas e até mesmo formas de atendimento. Os dicionários caracterizam a modalidade como sendo "uma maneira de ser peculiar" ou um "modo de existir", ou então, uma "forma, aspecto ou característica" de algo (coisa, ato, pensamento, organização etc. - por exemplo, ensino). Aparece, ainda, como "cada aspecto ou maneira diferente das coisas", ou então, como "modo de ser" e "aspecto, feição de uma coisa". Essencialmente, é isso mesmo.

Na $L D B$, a modalidade aparece no Título $V$, que trata "dos Níveis e Modalidades de Educação e Ensino". Como Níveis Escolares são identificados apenas dois: o nível da Educação Básica e o Nível da Educação Superior. Para cada nível, são definidas Etapas. Na Educação Básica, as etapas da Educação Infantil, do Ensino Fundamental e do Ensino Médio. Na Educação Superior temos a etapa da Graduação e a etapa da Pós-graduação.
} 
a democratização do acesso a educação pode acontecer de forma mais rápida e ágil.

Atualmente, quando falamos de Educação a Distância uma das primeiras associações feita é com a tecnologia. Essa ligação parece-nos mais ou menos natural se considerarmos o grande impulso que essa modalidade ganhou com os avanços das tecnologias da informação e da comunicação, destacadamente a Internet.

No entanto, muitas vezes temos a impressão que o meio se tornou mais importante que o fim. Isto é, encontramos muitas publicações falando de sistemas informatizados para a educação a distância, ferramentas disponíveis nesse ou naquele sistema, número de encontros presenciais, relatos de experiências pontuais quanto ao uso dos sistemas por alunos e professores etc. $\mathrm{O}$ que nos transmite a idéia que ainda estamos focados na ferramenta, ou seja, no veículo de transmissão de informação, e não na possibilidade de uma educação que não necessita a presença física de professores e alunos em um mesmo tempo e espaço.

Na Educação Básica, o Ensino Fundamental e o Ensino Médio podem ser cursados segundo duas diferentes modalidades: na modalidade do ensino regularmente oferecido, seqüencialmente, na idade própria, ou na modalidade de EJA - Educação de Jovens e Adultos, supletivamente oferecido "àqueles que não tiveram acesso ou continuidade de estudos na idade própria". Outra modalidade de ensino aparece de forma integrada "aos diferentes níveis e modalidades de educação", como sendo "Educação Profissional e Tecnológica". Veja só a confusão: "modalidade integrada com modalidade". Essa Educação Profissional e Tecnológica abrange a "Formação Profissional e Continuada ou Qualificação Profissional", a "Educação Profissional Técnica de Nivel Médio" e a "Educação Profissional Tecnológica, de Graduação e Pós-graduação" - para mim são três modalidades de Educação Profissional. A Educação Profissional Técnica de Nivel Médio (veja só a confusão entre nível e etapa do nível da educação básica), por sua vez, pode ser desenvolvida nas formas "integrada ao ensino médio", ou "concomitante com o ensino médio", ou ainda, "subseqüente ao ensino médio". Para complicar um pouco mais, tudo isso pode ser desenvolvido na modalidade de ensino presencial, ou na modalidade de Educação a Distância - EAD, ou então, ser oferecido de modo presencial, com utilização de metodologias complementares de educação a distância, ou ser programado como um curso na modalidade EAD, com momentos presenciais. Até aqui, ainda estamos utilizando o termo modalidade de ensino com significado muito próximo ao caracterizado pelos nossos dicionários. $O$ assunto fica um pouco mais complicado quando o termo modalidade de ensino é aplicado à Educação Especial, já que adotamos o modelo da "Educação Inclusiva", mas aí a LDB afirma que essa "modalidade de educação escolar" deve ser "oferecida preferencialmente na rede regular de ensino". Esse conceito de modalidade é utilizado, ainda no âmbito da Educação Especial, para o "ensino de LIBRAS - a Linguagem Brasileira de Sinais". Seria aplicada ainda, também à "educação escolar bilíngüe e intercultural aos povos indígenas"? Este é o cenário no qual navega o conceito de "modalidade de ensino" ou "modalidade de educação", ou "modalidade escolar" na LDB da Educação Nacional. 
É preciso ter claro que, seja qual for a modalidade ou os instrumentos utilizados, estamos falando de Educação. A partir desse pressuposto é de fundamental importância que consideremos os estudos, conhecimentos e saberes da educação presencial, na educação a distância, respeitando as especificidades das duas modalidades.

Frente ao exposto, são objetivos da presente pesquisa:

1) Analisar a legislação e documentos orientadores para cursos a distância e as diretrizes nacionais para cursos presenciais quanto à avaliação da aprendizagem e a legislação e documentos orientadores para cursos a distância no esforço de identificar aproximações e/ou contradições;

2) Analisar Projetos Pedagógicos e/ou manuais de instruções para a realização de cursos para a modalidade a distância com o intuito de identificar concepções de avaliação que sustentam tais projetos;

3) Estabelecer um quadro de princípios para a avaliação da aprendizagem em cursos a distância.

Assim, esta pesquisa procurou responder ao seguinte problema central: no atual estágio de desenvolvimento e oferta da Educação a Distância, quais os pressupostos legais que definem a avaliação da aprendizagem e como ela vem sendo considerada nos Projetos Pedagógicos e outros documentos orientadores para os cursos do nível superior? 


\section{Marco teórico}

\section{AVALIAÇÃO DA APRENDIZAGEM}

Quando um professor decide por uma ou outra forma de avaliar a aprendizagem dos seus alunos ele, mesmo sem saber, pauto-se em um conjunto de pressupostos e elementos valorados. Esse conjunto de pressupostos pode se denominado de "abordagem do processo ensino-aprendizagem", como diz Mizukami. ${ }^{4}$

A abordagem que o professor se baseia para a sua atuação docente, e, que faz com que frequentemente, insistamos no "mesmo sem saber", reflete uma visão de: mundo, homem, sociedade-cultura, conhecimento, educação, escola, ensino, aprendizagem, relação professor-aluno, metodologia e avaliação.

Sendo assim, podemos afirmar que nenhuma ação docente, o que envolve a avaliação, é neutra.

O que é avaliar?

Avaliar é, antes de tudo, estabelecer a valia ou o valor de algo. E, nas palavras de Hadji, "avaliar é sempre um processo que nos leva e emitir opiniões sobre uma dada realidade, num certo contexto e tendo como principal referente um conjunto de expectativas." 5

No nosso entender esse "conjunto de expectativas" baseia-se em concepções de mundo e de educação que, segundo LUCKESI $^{6}$, são traduzidas em práticas pedagógicas. Sendo assim, a avaliação da aprendizagem não é algo isolado e nem existe por sim só, ela sempre está relacionada a uma teoria e a uma prática.

\footnotetext{
${ }^{4}$ MIZUKAMI, Maria da Graça Nicoletti. Ensino: as abordagens do processo. São Paulo: Editora Pedagógica e Universitária, 1986.

${ }^{5}$ HADJI, C. A avaliação, regras do jogo: das intenções aos instrumentos. Portugal: Porto Editora, 1994. Paris,

${ }^{6}$ LUCKESI, C.C. Avaliação da aprendizagem escolar. São Paulo: Ed. Cortez, 2005. 16ª Ed.
} 
Entendemos que existem basicamente duas concepções de mundo e consequentemente duas concepções de educação. A primeira concepção considera que o mundo está pronto e que ao homem só cabe se adaptar as condições já existentes e estabelecidas. Essa adaptação poderá se dar por meio da escolarização, ou seja, da educação. A segunda considera que o mundo é um constante vir a ser e que é construído nas relações entre os indivíduos. À educação cabe o papel de oferecer meios e recursos para que os educandos possam ser sujeitos ativos e participantes dessa construção. Nesse sentido LUCKESI ${ }^{7}$ resumiu os ensinamentos do professor Paulo Freire dizendo que pode haver dois tipos de pedagogia: a que pretende domesticar os educandos e as que pretendem humanizar os educandos. O primeiro tipo objetiva adequar os alunos ao modelo social vigente, enquanto o segundo deseja oferecer meios e recursos pelos quais o educando possa ser sujeito da realidade social.

Considerando que o nosso foco é a avaliação da aprendizagem não nos deteremos na análise das "pedagogias", no entanto não podíamos deixar de pontuar nosso entendimento sobre o tema, já é que a partir das concepções de mundo e de educação é que se constroem as concepções de avaliação da aprendizagem, já que ela não pode ser considerada um fim em si mesma, mas apenas um meio para concretizar nossas concepções de educação e de mundo.

Com o exposto acima podemos dizer que da mesma forma que existem dois tipos de pedagogia, existem duas formas de compreender e fazer a avaliação da aprendizagem. Uma delas, que é condizente à pedagogia que deseja domesticar os educandos e a outra que vê o aluno como sujeito participante e construtor da realidade. A avaliação na pedagogia que domestica está preocupada em verificar se o aluno sabe repetir pontualmente e exatamente o que foi "transmitido" em sala de aula. Seu resultado classifica os alunos que estão "preparados" e exclui os que não estão aptos a participar de um mundo já pronto e acabado. O papel da avaliação na pedagogia que parte do princípio que o aluno é um sujeito participante e que a

\footnotetext{
${ }^{7}$ LUCKESI, C.C. Avaliação da aprendizagem escolar. São Paulo: Ed. Cortez, 2005. $16^{\text {a Ed. }}$
} 
escola deve oferecer meios para tal não é o de classificar ou excluir, mas sim de ser mais um dos instrumentos que podem colaborara e facilitar a aprendizagem.

Queremos explicitar, nesse momento, que sempre procuramos trabalhar sob os princípios de uma pedagogia que humaniza, que entende o aluno como sujeito ativo e responsável por sua aprendizagem e pela construção da realidade da qual participa. Para tanto, entendemos que a avaliação da aprendizagem deve ser mais um dos recursos que auxilia o aluno no processo de aprendizagem e na apropriação de meios para participar da sociedade. Como recurso de processos educacionais humanizadores, a avaliação deve ser formativa, isto é uma avaliação que auxilia, professores e alunos nos processos de ensinar e aprender.

\section{Momentos de avaliação}

A avaliação da aprendizagem pode ser classificada em função de diversos critérios. Neste trabalho optamos por priorizar o critério relacionado ao momento em que ela ocorre na ação de formação ${ }^{8}$, por percebemos que essa linha de análise permite uma identificação bastante clara dos princípios que norteiam a avaliação da aprendizagem. Segundo esses parâmetros a avaliação da aprendizagem pode ocorrer antes, durante ou depois da ação de formação, recebendo as denominações de prognóstica, formativa e cumulativa, respectivamente.

A avaliação prognóstica acontece antes da ação de formação e tem por objetivo possibilitar que o professor faça ajustes nos programas em função das necessidades e características dos alunos ou, encaminha-los a outros programas ou cursos. $\mathrm{HADJI}^{9}$ destaca que a avaliação prognóstica foi, durante muito tempo, denominada de diagnóstica, mas que atualmente deixou de ter essa nomenclatura porque se percebeu que toda avaliação pode ser diagnóstica a partir do momento que identifica certas características dos alunos.

A avaliação que ocorre depois da ação de formação recebe o nome, segundo Charles Hadji, de cumulativa, mas outros atores a denominam de somativa. Ela tem

\footnotetext{
8 "Pode-se entender por ação de formação tanto uma breve seqüência quanto algo muito mais longo" (HADJI, 2001 p.19)

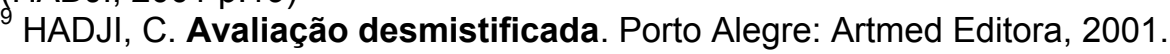


como objetivo verificar se o aluno aprendeu o que estava previsto pela formação e tem intenção certificativa, mesmo que não ofereça um certificado propriamente dito.

A avaliação formativa ocorre ao longo da ação de formação, pois ela objetiva oferecer informações aos alunos e professores sobre o desenvolvimento do processo de ensino e aprendizagem. Tais informações permitem que o professor reveja estratégias, refaça seu planejamento com o intuito de facilitar a aprendizagem. Para o aluno ela pode servir como mecanismo regulador do seu próprio processo de aprendizagem, identificando suas dificuldades e avanços.

No entanto, apenas o momento em que ocorre a avaliação não garante que ela seja ou não formativa. Não basta estar no centro da ação para ser formativa. O que se faz com os resultados da avaliação dizem muito mais da sua intenção do que o momento em que ela ocorre. Para ser formativa a avaliação deve servir para que o professor perceba e repense seu trabalho pedagógico e para que o aluno perceba suas potencialidades e dificuldades. Uma avaliação só é formativa se for informativa e, ela de fato se caracterizará como formativa dependendo das ações do professor e do aluno frente aos resultados ou informações que ela fornecer. Ou seja, é a intenção em favorecer a aprendizagem que torna uma avaliação formativa.

Dessa forma a avaliação é um dos momentos da ação educativa que deve estar a serviço da aprendizagem e não como elemento de exclusão ou classificação.

Para Hadji a avaliação formativa

não é um modelo científico, nem um modelo de ação diretamente operatório. Não é mais do que uma utopia promissora, capaz de orientar o trabalho dos professores no sentido de uma prática avaliativa colocada, tanto quanto possível, a serviço das aprendizagens ${ }^{10}$.

Complementando o conceito de avaliação formativa PERRENOUD ${ }^{11}$ diz que "É formativa toda avaliação que ajuda o aluno a aprender e a se desenvolver, que

\footnotetext{
${ }^{10}$ HADJI, Charles. Avaliação desmistificada. Tradução de Patrícia Ramos. Porto Alegre: Artes Médicas, 2001.

${ }^{11}$ PERRENOUD, Philippe. Avaliação: da excelência à regulação das aprendizagens entre duas lógicas. Tradução de Patrícia Ramos. Porto Alegre: Artes Médicas, 1999.
} 
participa da regulação ${ }^{12}$ das aprendizagens e do desenvolvimento no sentido de um projeto educativo".

A partir de tais conceitos compreendemos que o que define a avaliação formativa ou, em outras palavras o que caracteriza uma avaliação como formativa é a possibilidade de usar seus dados como informações para a reorientação do trabalho pedagógico, tanto por parte do aluno como do professor, para garantir a aprendizagem. Sendo assim, sua essência é muito mais ampla do que simplesmente o fato de ser realizada continuamente durante ação de formação.

Em outras palavras podemos dizer que uma avaliação pode ser ou não formativa dependendo do que fazemos com seus resultados. Se eles servirem apenas para dar uma nota, classificar, aprovar ou reprovar, independentemente no momento em que ocorra, ela não é formativa. Mas se os resultados forem usados a favor da aprendizagem ela é formativa.

A avaliação formativa prevê uma relação de diálogo entre aluno e professor, pois ambos estão interessados e são responsáveis pela aprendizagem. O professor desempenha o papel de facilitador da aprendizagem. Diferentemente das avaliações que objetivam aprovar ou reprovar que concentram o poder na figura do professor e que como fiel representante da sociedade no que tange ao do conhecimento já estabelecido tem o juízo final sobre se o aluno reproduziu corretamente o conhecimento "transmitido" ou, se o aluno "adquiriu" ou não o conhecimento.

O uso dos termos transmissão e aquisição do conhecimento compõem o conceito de educação bancária criado, como termo, e amplamente criticado pelo professor Paulo Freire. Não é possível transmitir ou adquirir conhecimento uma vez que ambas as ações são externas, isto é, a ação de transmitir implica que alguém está passando algo para outra pessoa, como se transmite um cargo, por exemplo e, adquirir nos remete a idéia de compra de algo já pronto. O conhecimento não pode ser nem

\footnotetext{
${ }^{12}$ Perrenoud define regulação dos processos de aprendizagem, num sentido amplo como o "conjunto das operações metacognitivas do sujeito e suas interações com o meio que modificam seus processos de aprendizagem no sentido de um objetivo definido de domínio". Numa variante mais simples seria a manutenção de um estado estável. Para esse autor falar de regulação no processo de aprendizagem guarda um sentido metafórico. (Perrenoud, 1999:90)
} 
transmitido e nem adquirido. O conhecimento é comunicado por meio de informações aos alunos que aos se apropriarem dessas informações e agir sobre elas, constroem o conhecimento. Sendo assim, reiteramos os ensinamentos do professor Paulo Freire no sentido de que o conhecimento é construído pelo sujeito que aprende. Ou, nas palavras de HADJI ${ }^{13}$, "o sujeito que aprende é o "motor" central do seu próprio desenvolvimento, e a aprendizagem traduz-se aí por uma complexificação crescente da sua estrutura cognitiva ${ }^{14 " .}$

\section{Instrumentos de avaliação da aprendizagem}

Antes de começarmos a trabalhar com os instrumentos de avaliação ou como Charles Hadji chama, dispositivos de avaliação, propriamente ditos, é preciso retomar algumas questões históricas em relação a eles.

Durante muito tempo, os cursos de formação de professores tinham um componente curricular que tratava de ensinar as técnicas de elaboração e aplicação de cada instrumento de avaliação. Normalmente, a ênfase era exclusivamente tecnicista, isto é, o uso da técnica pela técnica. Que segundo Vasconcellos ${ }^{15}$, com essa prática "tem-se a impressão de que existiria algo mágico, alguma fórmula secreta que levaria a avaliar bem, num jogo inconsciente, como se todo o resto não influenciasse, como se fosse possível preparar um bom instrumento e com isso "salvar" todo o processo educativo." Mas, gradativamente, com novas reflexões sobre o papel da avaliação da aprendizagem no processo educacional, tal componente foi desaparecendo dos quadros curriculares e em alguns momentos e círculos era quase proibido falar em "instrumentos" em educação, pois quem o fizesse seria imediatamente taxado de retrógrado, contra uma atitude de crítica sobre a educação e outros adjetivos pouco elogiosos. Com isso, no nosso entender “jogamos a criança, a bacia e água fora, quando apenas era necessário trocar a

\footnotetext{
${ }^{13}$ HADJI, C. A avaliação, regras do jogo: das intenções aos instrumentos. Portugal: Porto Editora, 1994.

${ }^{14}$ Segundo Hadji: cognitiva: conjunto organizado de processos operatórios e de conceitos que define "o estado intelectual" de um sujeito num dado momento.

${ }^{15}$ VASCONCELLOS, C. dos S. Avaliação da Aprendizagem: práticas de mudança. São Paulo: Libertad, 2008
} 
água que estava suja." Utilizamos uma expressão popular para expressar nossa crítica a posições extremadas.

Não compactuamos com o pressuposto que bastam bons e bem preparados instrumentos de avaliação para salvarmos o processo educacional. No entanto, não é ignorando-os que garantimos uma educação com qualidade e justa. Apenas reflexões críticas não ajudam a resolver o problema da avaliação. Temos visto e ouvido, na nossa trajetória profissional, muitos professores com lindos discursos sobre a avaliação da aprendizagem e em vários encontramos afirmações muito claras "como não fazer", ou, "o que não deve ser feito", mas pouco ou nada ouvimos sobre "como fazer", "por quê fazer" e "para que fazer".

Defendemos a idéia que é preciso conhecer os possíveis instrumentos que podem ser utilizados na avaliação da aprendizagem, da mesma forma que é preciso ter clareza que a avaliação da aprendizagem reflete as concepções de mundo, sociedade, homem e educação. Logo, não é a técnica ${ }^{16}$ pela técnica, mas como os instrumentos ou dispositivos serão usados, já que a técnica, assim como os instrumentos, não tem valor em si mesmo, mas o uso que fazemos deles é que garantem a intenção do ato educacional, da mesma forma que apenas o momento em que ocorre a avaliação não garante que ela seja ou não formativa. E, como afirma BARLOW ${ }^{17}$

Estudar os meios de avaliação não significa deixar de realizar a elevada e nobre pedagogia conceitual em troca de uma visita guiada ao setor de acessórios. Significa, ao contrário, situar-se em pleno cerne da ação pedagógica - sendo esta, antes de tudo, um fenômeno de comunicação,

Pois, como afirma HADJI ${ }^{18}$

Devemos abordar concretamente essa questão do dispositivo. Ainda que a avaliação formativa não se limite a priori a nenhum dispositivo (desse ponto de vista, não há nenhum dispositivo modelo, infalivelmente adequado), toda avaliação instituída exige um dispositivo mais ou menos elaborado.

\footnotetext{
${ }^{16}$ Técnica entendida como conjunto de procedimentos.

${ }^{17}$ BARLOW, M. Avaliação Escolar: mitos e realidades. Porto Alegre: Artmed, 2006.

${ }^{18}$ HADJI, C. Avaliação Desmistificada. Porto Alegre: Artmed Editora, 2001.
} 
Esse panorama tem assumido um caráter perigoso em educação a distância via internet, principalmente porque a maioria dos $\mathrm{LMS}^{19}$ é construída por profissionais que não são da educação. Sendo assim, eles colocam a disposição dos usuários instrumentos de avaliação que atendem as questões técnicas de programação e de acordo com os limites e potencialidades do software em si, não considerando as questões educacionais. Mesmo quando há a participação de educadores na elaboração de um LMS, normalmente as questões educacionais ficam subordinadas as soluções da informática. Sendo assim, é difícil encontrar alguma reflexão sobre os processos de avaliação em cursos a distância via internet. O que vemos é a simples utilização dos instrumentos disponíveis nos LMS e, de uma forma ou outra, vemos a educação a mercê da "técnica", aqui, novamente, referenciada como um conjunto de procedimentos ligados a uma ciência, no caso a informática.

Frente ao exposto, cremos ser relevante a análise dos instrumentos ou dispositivo de avaliação da aprendizagem sob a perspectiva que apresentamos abaixo.

São vários os instrumentos que podem servir para a avaliação, mas trabalharemos com alguns deles com a intenção de refletirmos sobre a possibilidade de uso em cursos a distância via internet. Para tanto, apresentaremos os instrumentos, uma breve descrição, as vantagens de cada um deles, alguns dos cuidados ${ }^{20}$ que devem ser tomados, sua abrangência tendo sob fundamento a taxonomia de Merril $^{21} \mathrm{e}$, por fim sua viabilidade na educação a distância.

\footnotetext{
${ }^{19}$ Sigla da expressão "Learning Management System" , refere-se a um sistema de informática com um conjunto de funcionalidades para a educação a distância via internet.

${ }^{20}$ Optamos por usar o termo "cuidados" e não outro qualquer em oposição a "vantagens" pois acreditamos que um instrumento não é bom nem ruim em si mesmo, mas ele sempre dependerá do uso que fazemos dele. Sendo assim, o termo cuidado representa a possibilidade de obtermos o que há melhor em cada proposição.

${ }^{21}$ Transcrevo de forma simplificada, a teoria de M. David Merril, reinterpretada por Jarbas Novelino Barato in Educação Profissional: saberes do ócio ou saberes do trabalho? São Paulo: SENAC, 2004, com quem convivi e trabalhei durante alguns anos, que muito me ensinou e muito me fez aprender. Para Merril o conhecimento pode ser classificado em: Fato, Conceito, Processo e Princípio.

"Fato é uma associação bidirecional entre um evento, objeto ou símbolo singular e um termo que o designa. Conceito é uma constituição de categorias correspondentes a conjuntos de eventos, objetos ou situações que recebem um mesmo nome e compartilham determinadas características.

Processo é a constituição de seqüências de ações tendo em vista a elaboração de um produto ou a obtenção de um resultado previamente definido.

"Princípio é a formulação de associações causais entre fenômenos, situações ou objetos."
} 
Estamos considerando o termo instrumento a partir da definição apresentada pelo dicionário eletrônico Houaiss da língua portuguesa, versão 1.0.5a, isto é:

\begin{abstract}
objeto simples ou constituído por várias peças, que se usa para executar uma obra, levar a efeito uma operação mecânica, fazer alguma observação ou mensuração (em geral trabalhos delicados e de precisão); dispositivo, apetrecho, ferramenta e, em sentido figurado "recurso que se utiliza para chegar a um resultado; meio.
\end{abstract}

Partindo do sentido figurado e reiterando a concepção de HADJI ${ }^{22}$ para dispositivos como sendo "o conjunto das modalidades previstas de levantamento e tratamento da informação", entendemos que um instrumento ou dispositivo de avaliação é um meio para obtermos informações sobre os processos de ensino e aprendizagem.

Ressaltamos que verificamos ou avaliamos o conhecimento do aluno por meio do seu desempenho porque concebemos o conhecimento como algo próprio do indivíduo e, portanto não passível de mensuração. Podemos nos aproximar e avaliar o que o aluno sabe apenas por meio do seu desempenho, de suas ações, do que ele pode, consegue e que comunicar sobre o que conhece.

Do conjunto de instrumentos possíveis de serem utilizado para a avaliação da aprendizagem, selecionamos: questões de múltipla escolha; prova dissertativa; questões objetivas de respostas curtas; preenchimento de lacunas; portfólio, webquest e auto-avaliação. Os critérios que orientaram nossa escolha estão baseados na "popularidade" de alguns nos diferentes sistemas de ensino e na percepção de possibilidade de uso em cursos a distância.

\title{
QUESTÕES DE MÚLTIPLA ESCOLHA
}

\section{Descrição}

Consistem de questões que apresentam, inicialmente, um texto com uma pergunta direta ou um problema que é seguido por alternativas como proposições para atender a solicitação do texto inicial.

\footnotetext{
${ }^{22}$ HADJI, C. A Avaliação, regras do jogo: das intenções aos instrumentos. Portugal: Porto Editora, 1994.
} 
Por exemplo:

Quem assinou a Lei Áurea?

a) José Bonifácio

b) Infante Dom Henrique

c) Princesa Izabel

d) Marquês de Pombal

e) Rainha Elisabete

Vantagens

- Fácil aplicação

- Fácil correção

\section{Cuidados}

- Deve-se evitar, ao máximo, questões que dependam da subjetividade do autor ou de quem for corrigir a prova.

- É preciso ficar atento para que entre as alternativas não haja proposições que induzam ao erro.

- As questões precisam ser redigidas de forma clara e objetiva.

- Precisa haver um equilíbrio entre o nível de dificuldade das questões.

- É preciso evitar que, no texto, haja indícios sobre qual resposta é a correta

- Não permitir que haja mais de uma resposta possível.

- Apresentar um número de alternativas que não seja exaustivo, mas que dilua a possibilidade de acerto casual.

- É preciso construir todas as questões com o mesmo número de alternativas.

- Necessita de tempo para a elaboração.

\section{Abrangência}

Se bem elaboradas, questões de múltipla escolha podem trabalhar com a interpretação e aplicação de conceitos, além do raciocínio indutivo e dedutivo. 


\section{Viabilidade na educação a distância}

As questões de múltipla escolha constituem em um dos instrumentos mais presentes em educação a distância. A maioria dos LMS o coloca a disposição dos usuários com vantagens agregadas como a correção pelo próprio sistema, a apresentação de dados estatísticos como, por exemplo, questão com maior índice de acerto ou erro, criação de um banco de questões com escolha aleatória, entre outras.

\section{PROVAS DISSERTATIVAS}

\section{Descrição}

As provas dissertativas ou questões de redação, segundo Heraldo Vianna ${ }^{23}$, são formadas por questões que exigem que o aluno faça uma dissertação, uma redação, enfim elaborem um texto sobre determinado assunto. Segundo o mesmo autor as provas dissertativas podem avaliar diferentes habilidades como enumerar, comparar, discutir, definir, exemplificar, sintetizar, entre outras.

\section{Vantagens}

- Fácil elaboração.

- Permite a verificação de diferentes habilidades.

- Quase nula possibilidade de acerto casual.

\section{Cuidados}

- As questões precisam ser claras e devem ser evitadas as expressões, como por exemplo: "na sua opinião", pois a medida que eu peço a "opinião" do aluno, qualquer resposta que ele fornecer deve ser aceita como correta.

- Preferencialmente, as questões devem fazer referência a um autor ou teoria para apontar o que está sendo avaliado. Por exemplo: "descreva o processo de desenvolvimento infantil, segundo Piaget", ao invés de simplesmente "descreva o processo de desenvolvimento infantil".

- O professor deve elaborar os critérios de correção antes mesmo de aplicar a prova, o que permitirá avaliar a adequação e viabilidade da questão. Chamamos

\footnotetext{
${ }^{23}$ VIANNA, Heraldo Marelim, Avaliação Educacional: Teoria-Planejamento-Modelo, São Paulo: IBRASA, 2000
} 
de critérios a seleção dos itens ou tópicos que devem ser abordados nas respostas.

- Por exigir bastante atenção na hora da correção para que a subjetividade do avaliador seja minimizada sugere-se que o nome do aluno não seja conhecido, que uma mesma questão de todas as provas seja corrigida e não cada prova separadamente.

\section{Abrangência}

Esse instrumento tem abrangência ampla, pois permite trabalhar com uma gama bastante grande de habilidades que foram citadas na própria descrição.

\section{Viabilidade na educação a distância}

Esse instrumento pode ser utilizado em educação a distância, desde que após a correção o professor-tutor redija cuidadosamente o feedback e informe os alunos o seu desempenho de forma descritiva e não apenas por meio de uma nota ou conceito.

\section{QUESTÕES OBJETIVAS DE RESPOSTAS CURTAS}

\section{Descrição}

O instrumento apresenta uma pergunta objetiva e requer uma reposta única e curta.

Exemplo:

Diga qual o ano considerado como o de termino da segunda guerra mundial?

\section{Vantagens}

- Fácil elaboração.

- Fácil correção.

- Reduzida possibilidade de acerto casual.

\section{Cuidados}

- Redigir a questão de forma que a resposta seja breve e precisa, limitando-se a um número, palavra ou frase curta. 


\section{Abrangência}

Esse instrumento tem abrangência restrita, pois trabalha basicamente com fatos e avalia, principalmente, a capacidade de memorização dos alunos.

\section{Viabilidade na educação a distância}

Esse instrumento é bastante utilizado em cursos a distância e inclusive faz parte de uma boa parte dos LMS.

\section{PREENCHIMENTO DE LACUNAS}

Descrição

Consiste em, normalmente, um ou duas frases com palavras omitidas, configurandose em espaços em brancos que devem ser preenchidos.

Há duas possibilidades de apresentação desse instrumento: sem nenhuma informação sobre a palavra a ser colocada na lacuna ou, indicando o que deve ser escrito no espaço em branco.

Por exemplo:

No período os jesuítas eram os responsáveis pela no Brasil.

As pessoas (estar, pretérito) conversando enquanto (aguardar, pretérito) o trem.

\section{Vantagens}

- Fácil elaboração.

- Fácil correção.

- Reduzida possibilidade de acerto casual.

\section{Cuidados}

- As palavras ocultas não devem ser as essenciais para a compreensão da frase.

- É necessário haver um equilíbrio entre as palavras e as lacunas, para que não se torne muito óbvio ou indecifrável.

- Mostra muito mais a capacidade de memorização dos alunos do que sua compreensão ou conhecimento.

- Trabalha basicamente com fatos. 
- O erro do aluno não permite inferir quais são as dificuldades de aprendizagem ou se elas existem, pois pode ter sido apenas uma falha na memorização.

\section{Abrangência}

Esse instrumento tem abrangência restrita, pois trabalha basicamente com fatos e avalia, principalmente, a capacidade de memorização dos alunos. Mesmo quando as lacunas relacionam fatos ou enunciam princípios, a memorização é a habilidade mais privilegiada.

\section{Viabilidade na educação a distância}

Esse instrumento é bastante utilizado em cursos a distância e inclusive faz parte de uma boa parte dos LMS, apesar de ser usado como faríamos em um papel e sem a riqueza do trabalho permitido pelo software Investigando Textos com Sherlock ${ }^{24}$. Podemos afirmar, com total segurança que com algumas poucas horas de programação os princípios desse software poderiam ser incorporados em sistemas de gerenciamento de ensino a distância.

\section{PORTFÓLIO}

\section{Descrição}

O conceito de portfólio surgiu no mundo artístico e denomina um conjunto de trabalhos/produções de um profissional para divulgar o que tem realizado ou realizou na trajetória profissional. Por exemplo, um fotógrafo ou artista plástico constrói seu portfólio para divulgar seu trabalho. Mais recentemente ele vem sendo usado em

\footnotetext{
${ }^{24}$ O software Investigando Textos com Sherlock, concebido por David Carraher, foi desenvolvido pelo Serviço Nacional de Aprendizagem de SP, na década de 90. Tal software possibilita que o próprio professor coloque texto, escolhendo quais palavras serão ocultados, formando as lacunas. $O$ software apresenta vantagens em relação a clássica atividade de preenchimento, como: aceita sinônimos; corrige erros ortográficos; fornece "dicas"; trabalha com textos e não apenas uma ou duas frases, entre outras. As citadas "vantagens" são atributos que o professor pode ou não permitir dependendo dos seus objetivos educacionais. Estamos caracterizando tais atributos como vantagens, porque cremos que eles permitem e aceitem o raciocínio feito pelo aluno ao aceitar um sinônimo, por exemplo, não se limitando a memorização.

Outra vantagem que, cremos, merece ser destacada é o fato de trabalhar com textos e não apenas com uma ou duas frases, como normalmente temos vistos em seu uso clássico nas avaliações. Ao se deparar com um texto é muito mais fácil o aluno, a partir do contexto, entender o texto e "pensar" nas palavras que estão faltando.

É preciso salientar que o autor desse software sempre se negou a usá-lo como instrumento de avaliação e inúmeras vezes respondeu às pessoas que o questionavam sobre isso, muitas vezes, apontando a falta de um sistema de avaliação como uma falha, dizendo que ele havia concebido esse produto como um instrumento de ensino e aprendizagem e que ele não gostaria de vê-lo transformado em uma "prova". Sua atenção estava voltada para a aprendizagem.
} 
situações educacionais como instrumento de avaliação, num primeiro momento em cursos relacionados ao campo das artes e depois conquistando outros espaços. Sendo assim, nos parece natural que em um curso de fotografia os alunos construam seus portfólios com a intenção de ao mostrar seus trabalhos , demonstrem que aprenderam diferentes técnicas.

Podemos encontrar outros nomes para esse instrumento como: porta-fólios, processo-fólios, diários de bordo, dossiê e, mais recentemente, webfólio, que pode utilizar a web como espaço para o registro de todos os tipos de informação, como textos, áudios e vídeos, que como veremos, posteriormente, por suas características, a web permite a convergência de todas as mídias.

Cabe ressaltar que como todo e qualquer tipo de instrumento o portfólio ou webfólio, em situações de avaliação da aprendizagem, não é um fim em si mesmo, ele tem a função de mostrar o que o aluno aprendeu por meio de diferentes produções.

\section{Vantagens}

- Pode ser constantemente apreciado pelo professor, permitindo uma nova concepção de avaliação, diferente daquela de “provas, testes e exames”. Essa concepção aponta um novo olhar do professor sobre a própria avaliação.

- O aluno pode perceber com mais clareza o seu papel na construção do conhecimento.

- $\quad$ aluno pode perceber seu próprio desenvolvimento.

- O desempenho do aluno pode demonstrar mais fielmente o seu conhecimento, uma vez que minimiza a pressão do estresse associado a maioria dos instrumentos de avaliação.

- Permite "ver" as evidências do que foi construído em termos de conhecimento ao longo das situações de ensino e aprendizagem.

\section{Cuidados}

- O professor deve estabelecer com clareza os elementos que devem compor um portfólio

- Exige um acompanhamento e avaliação permanente do professor sobre os trabalhos. 
- É preciso tomar ter clareza e avaliar em instâncias diferentes os itens forma e conteúdo, pois um portfólio bonito e bem organizado nem sempre está correto do ponto de vista do conteúdo.

- O feedback dado ao aluno deve ser em claro em termos da forma e do conteúdo.

- O feedback dado aluno não pode se limitar ao está "certo ou errado", é necessário apontar com o máximo de clareza possível o que corretos, se pode se melhorado, o que está incorreto e o que é preciso fazer para chegar ao resultado esperado.

- O professor deve estabelecer com antecedência os critérios de avaliação e comunica-los aos alunos.

- Evitar confundir webfólio com diário pessoal.

\section{Abrangência}

O webfólio, como instrumento de avaliação, pode ser utilizado para avaliar fatos, princípios, processos e conceitos, uma vez que suporta diferentes mídias com os registros das produções do aluno.

No caso particular de avaliação de processos, sugerimos o registro do desempenho do aluno por meio de um vídeo ou, ainda, uma série de fotografias demonstrando a realização de determinada tarefa. Fotos ou vídeo um podem ser acompanhados de um texto que relate a reflexão do aluno sobre a tarefa ou atividade.

\section{Viabilidade na educação a distância}

Pelo descrito acima, o portfólio, ou melhor, o webfólio mostra-se um excelente instrumento de avaliação em cursos a distância via internet por vários motivos e que estão associados as suas vantagens.

O primeiro argumento a favor da utilização dos webfólios é que ele é um instrumento que tem um caráter processual e não pontual como uma avaliação presencial, seja qual for o instrumento usado no momento presencial.

Seu caráter processual permite que o próprio aluno possa perceber e avaliar sua aprendizagem, identificando os avanços e os pontos que merecem ser retomados ou 
revistos. Além da referida identificação, ele permite reflita sobre o seu próprio de aprendizagem. Para o professor o webfólio pode representar um excelente instrumento de acompanhamento contínuo do desenvolvimento do aluno e, com isso, ele ganha mais agilidade nas intervenções que possa vir fazer, tanto no que diz respeito a rever o planejamento e as estratégias, como as orientações que dará a cada um dos alunos.

Outro argumento que podemos trazer a favor do uso de webfólio como instrumento de avaliação da aprendizagem refere-se a facilidade de "socialização" das produções, isto é, todo o material feito pode ser colocado a disposição de várias pessoas, participantes ou não do curso, de forma ágil e segura. Podemos, por exemplo, recorrer à publicação de certos componentes do webfólio em uma área comum a todos os alunos do curso para que todos possam reconstruí-lo coletivamente, refletir sobre o que está sendo mostrado e inclusive realizar uma avaliação.

Podemos, ainda, apresentar mais um argumento a favor do uso do webfólio quando pensamos na apresentação nos trabalhos de conclusão de curso ${ }^{25}$, que refere-se a possibilidade de um especialista da área, que não faça parte do curso, possa avaliar e dar sua contribuição.

\section{WEBQUEST}

\section{Descrição}

Segundo Bernie Dodge, seu criador, "Webquest é uma atividade investigativa, em que alguma ou toda a informação com que os alunos interagem provém da Internet." A webquest, parte de um tema e de proposições de tarefas. Para resolver as tarefas é preciso consultar diversas fontes de informação como livros, vídeos e etc., mas principalmente a internet, segundo a definição do próprio autor. As fontes a serem consultadas, normalmente são indicadas pelo professor.

\footnotetext{
${ }^{25}$ Exigência de alguns cursos de graduação e em cursos de pós-graduação quando pode receber outras denominações como monografia, por exemplo.
} 


\section{Vantagens}

- Favorece o trabalho de autoria dos alunos.

- Favorece o trabalho em grupo e a aprendizagem cooperativa

- Se bem elaborada, ela permite que os alunos aprendam a acessar analisar, selecionar e transformar informações.

\section{Cuidados}

- É preciso elaborar as tarefas de forma que elas nãos sejam resolvidas por meio de meras cópias da internet, ou de qualquer outra fonte de informação.

\section{Abrangência}

A webquest tem uma abrangência bastante ampla uma vez que não se limita a fatos. Com a webquest os alunos podem, por exemplo, usar e aplicar conceitos e princípios para resolver as tarefas propostas.

\section{Viabilidade na educação a distância}

É indiscutível a viabilidade da aplicação da webquest na educação a distância. Ela, inclusive, pode ser realizada em grupos trabalhando a distância. Além disso, os produtos oriundos de uma webquest podem ser publicados no webfólio.

\section{AUTO-AVALIAÇÃO}

\section{Descrição}

Como o próprio nome diz a auto-avaliação é a avaliação que cada aluno faz sobre seu desempenho. Não se trata de atribuição de notas, mas da observação do desempenho, do reconhecimento do que foi aprendido e do que ainda precisa ser aprendido.

\section{Vantagens}

- Estimula a metacognição ${ }^{26}$

- O aluno pode perceber com mais clareza o seu papel na construção do conhecimento.

- $\quad$ O aluno pode perceber seu próprio desenvolvimento.

\footnotetext{
${ }^{26}$ Pensar ou analisar o próprio conhecimento.
} 


\section{Cuidados}

- Não confundir com a simples atribuição de nota ao aluno pelo próprio aluno.

- $\quad$ instrumento de auto-avaliação deve ser muito bem elaborado para que ajude o aluno a refletir sobre seu conhecimento e desempenho.

\section{Abrangência}

A auto-avaliação não trabalha diretamente com os itens da taxonomia de Merril, portanto entendemos que não cabe uma análise sobre sua abrangência.

\section{Viabilidade na educação a distância}

É perfeitamente possível usar a auto-avaliação em cursos a distância e, parece-nos bastante apropriado se pensarmos no trabalho com adultos.

\begin{tabular}{|c|c|c|c|c|}
\hline Instrumento & Vantagens & Cuidados & Abrangência & Viabilidade em EAD \\
\hline $\begin{array}{c}\text { Questões de múltipla } \\
\text { escolha }\end{array}$ & $\begin{array}{l}\text { Fácil aplicação e } \\
\text { correção }\end{array}$ & $\begin{array}{c}\text { Atenção e tempo para } \\
\text { a elaboração }\end{array}$ & Média. & $\begin{array}{c}\text { Bastante viável e está } \\
\text { presente na maioria } \\
\text { dos LMS }\end{array}$ \\
\hline Provas dissertativas & $\begin{array}{c}\text { Fácil elaboração. } \\
\text { Quase nula a } \\
\text { possibilidade de acerto } \\
\text { casual }\end{array}$ & $\begin{array}{c}\text { Evitar a subjetividade } \\
\text { no momento da } \\
\text { correção }\end{array}$ & Alta & $\begin{array}{l}\text { Viável, mas há } \\
\text { necessidade de uma } \\
\text { avaliação descritiva }\end{array}$ \\
\hline $\begin{array}{c}\text { Questões objetivas de } \\
\text { respostas curtas }\end{array}$ & $\begin{array}{l}\text { Fácil aplicação e } \\
\text { correção }\end{array}$ & $\begin{array}{c}\text { Atenção na elaboração } \\
\text { das questões }\end{array}$ & Restrita & $\begin{array}{c}\text { Bastante viável e está } \\
\text { presente na maioria } \\
\text { dos LMS }\end{array}$ \\
\hline $\begin{array}{l}\text { Preenchimento de } \\
\text { lacunas }\end{array}$ & $\begin{array}{c}\text { Fácil aplicação e } \\
\text { correção }\end{array}$ & $\begin{array}{c}\text { Atenção na elaboração } \\
\text { das lacunas }\end{array}$ & Restrita & $\begin{array}{c}\text { Bastante viável e está } \\
\text { presente na maioria } \\
\text { dos LMS }\end{array}$ \\
\hline Portfólio (webfólio) & $\begin{array}{c}\text { Participação ativa do } \\
\text { aluno }\end{array}$ & $\begin{array}{l}\text { Atenção quanto aos } \\
\text { critérios de avaliação }\end{array}$ & Alta & Bastante viável \\
\hline WebQuest & $\begin{array}{c}\text { Participação ativa do } \\
\text { aluno }\end{array}$ & $\begin{array}{c}\text { Atenção na elaboração } \\
\text { das tarefas }\end{array}$ & Alta & Bastante viável \\
\hline Auto-avaliação & $\begin{array}{c}\text { Participação ativa do } \\
\text { aluno }\end{array}$ & Atenção na elaboração & * & Bastante viável \\
\hline
\end{tabular}

Quadro 1 - Síntese dos instrumentos de avaliação

* como a auto-avaliação não trabalha diretamente com os itens da taxonomia de Merril, entendemos que não cabe uma análise sobre sua abrangência. 
Finalizamos essa parte do trabalho cientes que não esgotamos o assunto, o que não era nossa intenção e nem objeto primeiro da nossa pesquisa. Apenas julgamos pertinente dedicar algumas páginas a ele por sentirmos que, hoje em dia, pouca atenção é dada aos instrumentos que podem ser utilizados para a avaliação da aprendizagem e, como já dissemos, muitas vezes eles se resumem a possibilidades técnicas de programação dos LMS.

Reiteramos o pressuposto que não bastam bons dispositivos para termos boas práticas de avaliação da aprendizagem, mas desconhecer os instrumentos nada nos ajudará. Assim como apenas uma avaliação adequada não "salvará" um processo educacional, conhecer os instrumentos não "salvará" a avaliação.

Além disso, não basta sabermos elaborar bons dispositivos de avaliação. É preciso saber usar o instrumento certo, no momento certo, para o público certo e adequado ao conhecimento ${ }^{27}$ que será objeto de avaliação.

Mas devemos acrescentar ou quesitos a essa "fórmula". Dissemos que um instrumento de avaliação nos permite colher informações, logo é preciso saber o que fazer com essas informações. E, só saberemos o que fazer com as informações obtidas se tivermos feito um planejamento da avaliação que deverá responder questões tais como: "o que avaliar", "como avaliar" e "para que avaliar".

Caso o esse planejamento não seja feito ou não seja adequadamente pensado corremos o risco de não termos informações, apenas dados sem utilidade.

Um processo educacional é um conjunto de ações inseparáveis que envolve o planejamento, os objetivos, os conteúdos, as estratégias de ensino e a avaliação, permeados por uma intencionalidade que denuncia a visão de homem, mundo, sociedade e conhecimento.

\footnotetext{
${ }^{27}$ Conhecimento aqui entendido segundo a taxonomia de Merril.
} 


\section{EDUCAÇÃO A DISTÂNCIA}

Esta parte do nosso trabalho começará com a análise de alguns conceitos de "educação a distância" com o intuito de estabelecermos um norteador da nossa pesquisa.

A seguir apresentaremos uma breve história da educação a distância no mundo e, em particular no Brasil, sem a pretensão de esgotar todas as ações e investigações realizadas nessa área. Queremos apenas pontuar algumas experiências com a intenção de facilitar a compreensão dessa modalidade e ensino e sua evolução até o momento desse trabalho.

Após a revisão histórica faremos uma síntese dos principais meios de comunicação e, suas características, que foram e são utilizados para a realização da educação a distância.

Finda a revisão histórica, mostraremos as finalidades atribuídas à educação a distância e, para finalizar apresentaremos os dados que mostram o atual cenário da $E A D$, no Brasil, em termos da oferta e da demanda.

\section{Definição e conceito}

Ao longo da história, a educação a distância foi conceituada de várias formas. Portanto, não há uma única e consensual definição. As diferentes ênfases dadas aos elementos dos processos de ensino e aprendizagem e às mídias utilizadas na educação a distância, que a partir de agora passamos a chamar de EAD, contribuíram para a construção das diversas definições dessa modalidade de ensino. Vejamos alguns dos conceitos atribuídos à EAD:

O ensino a distância é o tipo de método de instrução em que os procedimentos docentes têm lugar à parte dos procedimentos discentes, de modo que a comunicação professor-aluno fica retardada no tempo, no espaço ou em ambos de uma só vez. Trata-se, pois, de um processo de ensino-aprendizagem que requer todas as condições gerais dos sistemas de instrução: planejamento prévio, orientação do processo, avaliação e retro alimentação, mas todos subordinados às possibilidades e limites intrínsecos do meio de que se vale a comunicação: textos, impressos, telefone, 
instrutor, rádio ou televisão (SARRAMONA, 1979: 1 1a $^{\text {Convenção }}$ Internacional de TV e Educação, apud GARCIA ARETIO, 1987, p.58).

O ensino a distância abrange as formas de estudo que não são dirigidas e/ou controladas pela presença do professor na aula, ainda que se beneficiem do planejamento, guia e ensinamentos de professores-tutores, ou através de algum meio de comunicação social que permite a interação professor/aluno, sendo este último o exclusivo responsável pelo ritmo e realização de seus estudos (ZAMORA, 1981, apud GARCIA ARETIO, 1987, p. 58).

A Educação a distância é o aprendizado planejado que ocorro normalmente em um lugar diferente do local do ensino, exigindo técnicas especiais de criação do curso e de instrução, comunicação por meio de várias tecnologias e disposições organizacionais e administrativas especiais. (MOORE \& KEARSLEY, 2007, p. 2)

A partir dos conceitos apresentados consideraremos, nesse trabalho, duas definições de EAD :

forma de ensino que possibilita a auto-aprendizagem, com a mediação de recursos didáticos sistematicamente organizados, apresentados em diferentes suportes de informação, utilizados isoladamente ou combinados, e veiculados pelos diversos meios de comunicação;(Art. 1 do Decreto Federal 2494/98)

modalidade educacional na qual a mediação didático-pedagógica nos processos de ensino e aprendizagem ocorre com a utilização de meios e tecnologias de informação e comunicação, com estudantes e professores desenvolvendo atividades educativas em lugares ou tempos diversos.(Art. $1^{\circ}$ do Decreto 5.562 de 19 de dezembro de 2005)

A escolha de tais definições e conceitos justifica-se por serem elas as definições legais que vigoram no país e por superar, a nosso ver, os equívocos de outras conceituações que partem do que não é para descrever o que seria. Tais equívocos podem ser frutos de comparações feitas com o ensino presencial, ou da tentativa de, a partir do ensino presencial, se construir "uma" definição para a educação à distância.

Além disso, essas duas definições se completam. Embora ambas tratem da mediação de recursos, dos meios e tecnologias de informação e comunicação, em nossa opinião elas complementam-se a medida que a primeira enfatiza a "autoaprendizagem' e a segunda explicita a noção de distância, "com estudantes e professores desenvolvendo atividades educativas em lugares ou tempos diversos", 
sem o caráter pejorativo e desatualizado da primeira definição quando diz que "a comunicação professor/aluno fica retardada no tempo, no espaço ou em ambas de uma só vez".

Mas cabe ainda lembrar que a legislação vigente criou, intencionalmente ou não, um critério para educação a distância na publicação da Portaria 2253, de 18 de outubro de 2001 e depois revogada pela Portaria MEC 4.059, de 10 de dezembro de 2004. As referidas portarias possibilitam, em cursos de graduação, a oferta de disciplinas não-presenciais em cursos presenciais reconhecidos. A partir de tais portarias, é possível utilizar até $20 \%$ da carga horária total de um curso de graduação em atividades a distância desde que se respeite a realização de avaliação presencial. Qualquer instituição de ensino superior, com cursos reconhecidos, pode oferecer disciplinas inteiras a distância ou distribuir percentuais diferentes em várias disciplinas, desde que no total não ultrapasse os $20 \%$ do tempo previsto para a integralização do currículo. Com isso, fica definido um patamar numérico que, uma vez ultrapassado, transforma um curso presencial a distância. Ou, de outra forma, se a carga horária a distância não for superior a $20 \%$ do total, temos um curso presencial; se tiver mais de $20 \%$ caracteriza-se um curso não-presencial, isto é, a distância.

Segundo Fragale Filho ${ }^{28}$, tais documentos "em seus considerandos, remetem ao art.81 da LDB/96 e ao art. 1 do dec. 2.494/98; isto é suas referências encontram-se na possibilidade de organização de cursos ou instituições de ensino experimentais e na conceituação legal de EAD. Isso quer dizer que trata a oferta parcial de conteúdos não-presenciais sob a rubrica do experimentalismo, não a incluindo, em sentido estrito, no universo relativo à EAD."

Esse último aspecto é particularmente interessante para a nossa pesquisa, pois se não há obrigatoriedade de integração entre o ensino presencial e não-presencial, como se dará a avaliação da aprendizagem?

\footnotetext{
${ }^{28}$ FRAGALE, Roberto Filho. Educação a distância: análise dos parâmetros legais e normativos. Rio de Janeiro: DP\&A, 2003.
} 


\section{História da Educação a Distância}

Muitos pensam que educação a distância é um assunto ou uma modalidade de ensino nova, moderna ou contemporânea. Algumas instituições usam essa idéia como argumento de marketing para venderem seus produtos e serviços. Mas se formos rigorosos com o conceito, podemos perceber que há um enorme equívoco nessa concepção.

Antes de traçarmos o percurso da educação a distância no Brasil, faremos uma pequena síntese da história da EAD no mundo.

Segundo Aretio ${ }^{29}$, "existem autores que se voltam às mais antigas civilizações para encontrar as origens do ensino por correspondência, germe da atual educação a distância." (p.55) Outros autores afirmam que a educação a distância teria começado com os sumérios, egípcios e gregos que, por meio de uma enorme rede de comunicação que abrangia todo o mundo antigo, distribuíam cartas com conteúdos instrutivos. A partir daí, ao longo da história, são muitos os exemplos de cartas com objetivos didáticos. Aretio ${ }^{30}$ cita, por exemplo, as epístolas de Platão a Dioniso, de São Paulo as primitivas comunidades cristãs e outras mais que a nosso ver tem a intenção de mostrar as ações realizadas para que informação ou instrução sejam divulgadas apesar das distâncias físicas. Ou seja, o homem sempre procurou superar as barreiras da distância, usando os recursos possíveis de cada época para comunicar idéias e instruções, ou divulgar leis e normas. Além disso, as referidas citações mostram que, pelo menos, o conceito de educação a distância não é algo exclusivo do nosso tempo.

Aretio ${ }^{31}$ afirma que "não há dúvidas que uma educação a distância "por correspondência", perto do que entendemos hoje como tal, inicia seu real desenvolvimento no mesmo compasso da expansão dos sistemas nacionais dos

\footnotetext{
${ }^{29}$ ARETIO, Lorenzo Garcia. La educación a distancia: de La teoria a La prática. Espanha: Editorial Ariel, 2006.

${ }_{30}$ ARETIO, Lorenzo Garcia. La educación a distancia: de La teoria a La prática. Espanha: Editorial Ariel, 2006.

${ }^{31}$ ARETIO, Lorenzo Garcia. La educación a distancia: de La teoria a La prática. Espanha: Editorial Ariel, 2006.
} 
correios, cuja origem se dá em 1680." O primeiro registro, apontado pelo autor, como oferta de ensino e tutoria a distância data de 1728 em um Jornal de Boston (EUA). A partir dessa data, encontramos dados sobre cursos a distância em várias regiões do mundo, como Europa, Estados Unidos e a antiga União Soviética que em entre 1940 e 1941 contava com 200.000 mil alunos inscritos em cursos superiores a distância.

No início do século, os avanços técnicos permitiram que as instituições utilizassem outros veículos de comunicação, além do meio impresso, para a realização da educação a distância. Em 1922, uma rádio norte-americana inicia programas educativos; em 1939 a Universidade de Lowa (EUA) oferecia um sistema de ensino por meio do telefone; em 1947, a Rádio Sorbonne, transmitia aulas de quase todas as matérias literárias da Faculdade de Letras e Ciências Humanas de Paris. Só para citar alguns exemplos.

Para que passássemos das aulas radiofônicas para cursos transmitidos pela televisão não levamos nem duas décadas. ${ }^{32}$

Ao estudar a história da educação a distância, percebemos uma enorme relação entre o desenvolvimento das tecnologias de comunicação e informação e essa modalidade de educação. Podemos dizer que o avanço tecnológico dos meios de comunicação e informação é forte aliado para o desenvolvimento da educação a distância. No entanto, não pode ser considerado o único fator. Além disso, não podemos, ingenuamente, pensar que uma determinada mídia era substituída à medida que um novo veículo de comunicação surgia. Isto é, com a utilização do rádio para a transmissão de aulas, a mídia impressa não foi abandonada e nem o rádio o foi quando da presença da televisão. Os novos meios de comunicação eram utilizados de forma a acrescentar novas possibilidades e não em caráter de substituição.

\footnotetext{
${ }^{32}$ Segundo Landim, em 1960 é fundada o Beijing Television College, na China.
} 
Alguns autores dizem que a internet substituirá todas as outras mídias a medida que ela permite a convergência de todas as anteriores. Sem deixar de reconhecer tal poder de convergência, deixaremos esse tema para capítulos posteriores.

Voltemos para a história da educação a distância.

Em 1969 foi criada a Open University Britannica, instituição verdadeiramente pioneira e sinalizadora do que hoje se entende como educação superior a

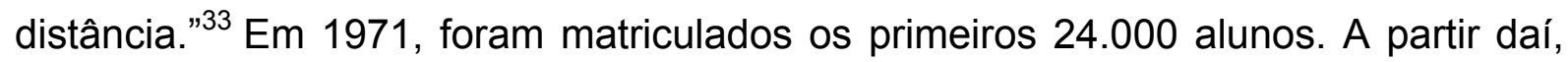
foram criadas muitas outras instituições, similares, na Europa: 1972 - Espanha; 1982 - Holanda; 1984 - Suécia; 1987 - Bélgica e França; 1988 - Portugal; 1990 Noruega.

Um fato marcante e que revela à seriedade que é atribuída, na Europa, à modalidade a distância de educação, foi a criação da European Association of Distance Teaching Universities, em 1987, com sede na Holanda e com o objetivo de fomentar a educação superior a distância na Europa.

Apesar de podermos encontrar embriões de educação a distância desde a antiguidade, é no período que segue a segunda guerra mundial que ela começa a ganhar mais espaço; nas duas últimas décadas o seu desenvolvimento tem sido expressivo em instituições no mundo todo.

\section{História da educação a distância no Brasil}

O Brasil tem uma história em educação a distância. Acredita-se que ela tenha iniciado no final século XIX, mas não temos registros das primeiras ações do ensino por correspondência desse período. ${ }^{34}$

Os primeiros documentos sobre a educação a distância no Brasil remetem a 1923, quando Edgar Roquette Pinto fundou a primeira emissora de rádio brasileira, a

\footnotetext{
${ }^{33}$ ARETIO, Lorenzo Garcia. La educación a distancia: de la teoria a la prática. Espanha: Editorial Ariel, 2006.

${ }^{34}$ CORREA, J. Sociedade da informação, globalização e educação a distância. Rio de Janeiro: SENAC, 2005. Curso de Especialização em Educação a Distância. CD-ROM.
} 
Rádio Sociedade do Rio de Janeiro, caracterizando-se como uma Rádio Educativa. A Rádio Sociedade se transformou na Rádio MEC ao ser doada, em 1936, para o então Ministério da Educação e Saúde, do governo de Getúlio Vargas, com a condição de que a Rádio Sociedade permanecesse fiel ao seu tema cultural e educativo, sem vinculação comercial, política ou religiosa. ${ }^{35}$

Dentre as suas atividades, há a TV Escola ou TVE, um canal de televisão do programa de Educação a Distância criado pelo Ministério de Educação e Desporto (MEC), com o objetivo de capacitar, aperfeiçoar, valorizar os professores e melhorar a qualidade do ensino nas escolas públicas do país. Este canal é transmitido para todos o país pelo satélite BrasilSat, captado por antena parabólica. Dentre a programação da TVE destaca-se o programa "Um salto para o futuro ", projeto de educação à distancia iniciado em 1991. Este programa tem na interatividade seu marco diferencial, pois reúne educadores de norte a sul do país, em 1500 telepostos, em uma recepção organizada para a discussão sobre o papel do professor nos dias de hoje, os fundamentos e metodologias que podem contribuir para sua prática e também os conteúdos e conceitos que devem ser trabalhados por eles nas escolas. ${ }^{36}$

Em 1939, foi criado o Instituto Monitor, primeira empresa brasileira a ofertar cursos profissionalizantes por correspondência. Os primeiros cursos oferecidos relacionavam-se à eletrônica e à formação de radiotécnicos. A experiência do Instituto Monitor foi seguida pelo Instituto Universal Brasileiro, fundado em 1941 e que se tornou o maior difusor de cursos profissionalizantes a distância do país. 0 Instituto Monitor adaptou-se às novas tecnologias, passou a oferecer vídeo aulas e a apresentar seus cursos na Internet.

Em 1947, o Sistema Nacional de Aprendizagem Comercial - SENAC, criou a Universidade do $\operatorname{Ar}$ (Uar) que oferecia cursos pelo rádio. Uma iniciativa do Departamento Regional de São Paulo, a Unar utilizava uma rede de emissoras na

\footnotetext{
${ }^{35}$ AVELAR, L. O rádio educativo no Brasil: de Roquette Pinto a Luis Inácio Lula da Silva. Florianópolis, 2004 (trabalho apresentado no II Encontro Nacional da Rede Alfredo de Carvalho - GT História da Mídia Educativa, sob a coordenação de Marlene Blois)

${ }_{36}$ Informações disponível no site http://www.multirio.rj.gov.br/cime/CE05/CE05 011.html, acesso em 01 out. 2009.
} 
capital paulista e no interior do estado. Os programas, gravados em discos de vinil, eram repassados às emissoras que programavam as emissões das aulas nos radiopostos três vezes por semana. Nos dias alternados, os alunos estudavam nas apostilas e corrigiam exercícios, com o auxílio dos monitores. A Unar atuou durante 15 anos. Ainda na década de 1940, outras divisões regionais do SENAC implantaram em seus estados cursos por correspondência e rádio para assegurar a educação aos comerciários.

Em 1961 tivemos o Movimento de Base, criado pela Conferência Nacional dos Bispos do Brasil e apoiado pelo Governo Federal, que objetivava oferecer educação de base por meio das emissoras de rádios católicas.

A partir de 1967, o Instituto Nacional de Pesquisas Espaciais (INPE) criou o Projeto SACI (Sistema Avançado de Comunicações Interdisciplinares) com a intenção de "experimentar o uso de satélites em educação, transmitindo programas de rádio e televisão para escolas de $1^{\circ} \mathrm{grau}$, escolhidas aleatoriamente entre todas as escolas municipais e estaduais do Rio Grande do Norte" ${ }^{37}$. O programa foi encerrado em 1974.

Entre o final da década de 60 e durante a de 70, a educação a distância parece ganhar mais força no Brasil. Temos:

Ensino por correspondência para o setor terciário oferecido pela IOB - Informações Objetivas Publicações Jurídicas;

É criada a Associação Brasileira de Teleducação, instituição privada, que mais tarde se tornaria Associação Brasileira de Tecnologia Educacional com "o objetivo de impulsionar no país, os esforços comuns e a aproximação mútua para o desenvolvimento quantitativo e qualitativo da tecnologia educacional, em favor da

\footnotetext{
${ }^{37}$ ANDRADE, A.A.M. Política e afeto na produção de identidades e instituições: a experiência potiguar. Revista Brasileira de Educação, n. 30, set./out./nov./dez., p. 133 a 181, 2005.
} 
promoção do Homem e da coletividade", ${ }^{38}$ que começou oferecendo programas de aperfeiçoamento do magistério do $1^{\circ}$ ao $3^{\circ}$ graus.

Cursos de $5^{\mathrm{a}}$ a $8^{\mathrm{a}}$ séries por meio de transmissões televisas e material impresso oferecidos, por exemplo, pelas emissoras do Maranhão e doCeará;

Em 1971 com a promulgação das Leis de Diretrizes e Bases (Lei $n^{\circ}$. 5692), é atribuído à educação à distância o caráter "experimental". Define-se, também, que seu funcionamento aconteceria a título precário, ficando sujeito a Pareceres dos Conselhos Federal e Estadual de Educação (Art.2 - § 2).

No Rio Grande do Sul, temos a oferta de cursos de educação não-formal de jovens, pela Fundação Educacional e Cultural Padre Landell.

Em São Paulo, é criada a Fundação Padre Anchieta, mantida pelo Estado de São Paulo com o objetivo de promover atividades educativas e culturais através do rádio e da televisão.

O Projeto Minerva, homenagem a deusa grega da sabedoria, nasceu no Serviço de Radiodifusão Educativa do Ministério da Educação e Cultura, por determinação de um decreto presidencial e uma portaria interministerial de $n^{\circ} 408 / 70$, que determinava a transmissão de programação educativa em caráter obrigatório, por todas as emissoras de rádio do país. A obrigatoriedade é fundamentada na Lei $5.692 / 71$.

É criado, pelo SENAC, o Sistema Nacional de Teleducação, que operava principalmente por meio do ensino por correspondência. No entanto, também realizou algumas experiências com rádio e TV. Além de cursos voltados para o setor do Comércio de Bens, Serviço e Turismo também oferecia cursos de instrumentação ou suplementação do ensino regular não atrelados às áreas de formação profissional.

\footnotetext{
38 Informações obtidas no site: http://abtbr.org. br/index. php?option=com content\&task=view\&id=30\&ltemid=42 visitado em outubro de 2009 .
} 
Em 1978, a Fundação Roberto Marinho e a Fundação Padre Anchieta lançam o Telecurso $2^{\circ}$ grau, caracterizando-se como sendo a primeira vez que uma emissora de televisão comercial era usada para um projeto educativo. Nos dias de hoje, juntamente com outros parceiros a Fundação Roberto Marinho, mantenedora da rede globo, continua a oferecer Telecursos de $1^{\circ}$ e $2^{\circ}$ graus. Os cursos, além de aulas na televisão, contam com material impresso e em alguns casos com orientadores de aprendizagem presencial.

Em 1979, a Universidade de Brasília (UnB), começa suas atividades em EAD oferecendo vários cursos, dos quais seis foram traduzidos da Open University. Além de alunos regularmente inscritos em seus cursos, a UnB publicou vários materiais, em forma de fascículos, em jornais de diferentes capitais brasileiras.

$\mathrm{Na}$ década de 80 , temos a continuidade dos projetos e programas iniciados no período anterior. Já na década de 90, parece-nos relevantes as ações referenciadas a seguir.

Em 1991, a Fundação Roquette Pinto lança o Programa "Um Salto para o Futuro" que objetivava a formação continuada de professores do ensino fundamental, que a partir da segunda metade dessa década passa a ser transmitido pela "TV- Escola", que além de atender ao objetivo inicial, passa a atuar como apoio aos cursos de formação de professores das séries iniciais do ensino fundamental. Além de programas televisivos, utiliza material impresso, rádio e telefone como veículos de comunicação.

Em 1992 o MEC criou a Coordenadoria Nacional de Educação a Distância e, em 1995, a Secretaria de Educação a Distância (Seed).

Em 1993 é firmado um convênio de cooperação técnica entre o Ministério de Educação e Desporto, o Ministério das Comunicações/Empresa Brasileira de Telecomunicações S/A - EMBRATEL, com a participação do Ministério da Ciência e Tecnologia, do Ministério da Cultura, do Conselho de Reitores das Universidades Brasileiras - CRUB, do Conselho de Secretários Estaduais de Educação - CONSED 
e da União Nacional dos Dirigentes Municipais da Educação - UNDIME, com os seguintes propósitos: explicitar princípios comuns que norteiam as partes nas atividades de integração do setor educacional às dimensões cultural, econômica e política da sociedade brasileira; conceber, desenvolver implantar e expandir a infraestrutura de informações do Sistema Nacional de Educação à Distância, representada por uma rede teleinformacional de educação (RTE): ampliar as disponibilidades de satélite para fins.

O Serviço Nacional de Aprendizagem Industrial, do Rio de Janeiro, a partir de 1993, criou o Centro de Educação a Distância. Utilizando material impresso com alguns momentos presenciais, deu início às suas atividades com os cursos de Noções Básicas de Qualidade Total e Elaboração de Material Didático Impresso.

O Decreto presidencial 1.237, de 06/09/94, criou, no âmbito da Administração Federal, sob a coordenação do Ministério da Educação e do Desporto, o Sistema Nacional de Educação a Distância (SINEAD).

O Decreto presidencial s/n, de 1994, criou no âmbito da Secretaria-Geral da Presidência da República, comissão encarregada de estudar e propor alternativas para integração do Programa Nacional de Educação à Distância com os meios oficiais de comunicação.

Em 1995 a Universidade Federal do Mato Grosso ofertou a primeira Licenciatura Plena Em Educação Básica.

Entre 1995/1996 foi inaugurado o Laboratório de Ensino a Distância do Programa de Pós-Graduação em Engenharia de Produção da USFSC.

Em 1996, a Lei de Diretrizes e Base da Educação Nacional (n. 9394/96, no Art. 80, a educação a distância passa a ser reconhecida como ensino regular.

Em 1996, a Universidade Católica de Brasília começou a oferecer cursos de especialização da distância. 
Em 1997, foi criado o Prolnfo ( Programa Nacional de Informática na Educação), desenvolvido pela Secretaria de Educação a Distância (SEED), por meio do Departamento de Infra-Estrutura Tecnológica (DITEC), em parceria com as Secretarias de Educação Estaduais e Municipais. O programa funciona de forma descentralizada, sendo que em cada Unidade da Federação existe uma Coordenação Estadual do Prolnfo, cuja atribuição principal é a de introduzir o uso das tecnologias de informação e comunicação nas escolas da rede pública, além de articular as atividades desenvolvidas sob sua jurisdição, em especial as ações dos Núcleos de Tecnologia Educacional (NTEs).

Em 1996, surgiu o Espaço Senac, um programa radiofônico inicialmente veiculado em emissoras do Nordeste e do Espírito Santo. A programação abordava não só temas ligados à educação profissional, mas também assuntos relacionados à qualidade de vida dos cidadãos

Em 1997, o MEC criou o e-proinfo

\begin{abstract}
Ambiente Colaborativo de Aprendizagem que utiliza a Tecnologia Internet e permite a concepção, administração e desenvolvimento de diversos tipos de ações, como cursos a distância, complemento a cursos presenciais, projetos de pesquisa, projetos colaborativos e diversas outras formas de apoio a distância e ao processo ensinoaprendizagem. ${ }^{39}$
\end{abstract}

A partir de 1998, o Departamento Nacional do SENAC criou O CEaD (Centro Nacional de Educação a Distância) com o objetivo de produzir cursos a distância, aberto a população em geral e, desenvolver projetos de capacitação dos profissionais da instituição.

No início do século $X X I$, com o status de educação regular, atribuído pela Lei de Diretrizes e Base da Educação Nacional (LDB), a educação a distância ganha, a cada dia, novos adeptos, novas iniciativas, novos formatos e quem sabe uma nova história.

\footnotetext{
${ }^{39}$ Informações obtidas no site http://eproinfo.mec.gov.br/fra eProinfo.php?opcao=1, visitado em outubro de 2009.
} 
Em 2000, são credenciadas, pelo MEC, as primeiras universidades para oferecerem cursos a distância.

Segundo GATTI e BARRETO ${ }^{40}$, O Plano Nacional de Educação, sancionado pela Lei $n^{\circ} 10.172 / 2001$, reitera a importância da EAD nas políticas de educação e estabelece diretrizes, objetivos e metas para a sua implementação. Para atender as demandas criadas na área, o plano dá ênfase à política de EAD para a formação de professores, propondo entre seus objetivos o aumento da oferta de cursos de formação docente em nível superior a distância e o apoio financeiro à pesquisa sobre EAD.

Em 2002, o Serviço Nacional de Aprendizagem Comercial e o Serviço Social (SENAC) do Comércio (SESC) criam a Rede de Teleconferências, com o objetivo de ser um espaço de debates sobre temas ligados a educação e trabalho, inclusão social, saúde, meio ambiente e muitos outros, além de capacitação de docentes.

Em 2004, o SENAC foi especialmente credenciado pelo Ministério da Educação para oferecer cursos de pós-graduação lato sensu a distância. Para tanto, foi criada a Rede EAD SENAC. Cabe à Rede, entre outras tarefas, a gestão, a produção e a oferta de cursos de pós-graduação a distância.

Em 2005, o governo brasileiro, criou a Universidade Aberta do Brasil, instituída pelo Decreto 5.800. de junho de 2006, com o propósito de capacitar professores da educação básica e, entre seus objetivos, destacamos:

Desenvolver a modalidade de educação a distância, com a finalidade de expandir e interiorizar a oferta de cursos e programas de educação superior no País, além de ampliar o acesso à educação superior pública levando tais cursos às diferentes regiões do país; oferecer cursos superiores para capacitação de dirigentes, gestores e trabalhadores em educação básica dos Estados, do Distrito Federal e dos Municípios e apoiar a pesquisa em metodologias inovadoras de ensino superior respaldadas em tecnologias de informação e comunicação. A Universidade Aberta do Brasil está pautada, segundo o MEC, em cinco eixos: Expansão pública da educação superior, considerando os processos de democratização e acesso; aperfeiçoamento

\footnotetext{
${ }^{40}$ GATTI, B. A. \& BARRETO, E. de Sá - Professores do Brasil: impasses e desafios, UNESCO Brasil , 2009
} 
dos processos de gestão das instituições de ensino superior, possibilitando sua expansão em consonância com as propostas educacionais dos estados e municípios; a avaliação da educação superior a distância tendo por base os processos de flexibilização e regulação em implementação pelo MEC; as contribuições para a investigação em educação superior a distância no país e financiamento dos processos de implantação, execução e formação de recursos humanos em educação superior a distância.

Também em 2005, o governo federal, por meio das Secretarias da Educação Básica e de Educação a Distância, criou o Programa Pró-licenciatura com o objetivo único de trabalhar com a formação inicial a distância de professores em serviço.

Em 2007, pelo Decreto n 6301, foi instituído o Sistema Escola Técnica Aberta do Brasil - e-Tec Brasil "com vistas ao desenvolvimento da educação profissional técnica na modalidade de educação a distância, com a finalidade de ampliar a oferta e democratizar o acesso a cursos técnicos de nível médio, públicos e gratuitos no País." ${ }^{42}$

Em 2009 a Secretaria de Ensino Superior do Estado de São Paulo lança os primeiros cursos semipresenciais da Universidade Virtual do Estado de São Paulo (Univesp), que promete oferecer cursos de graduação e cursos extra-curriculares de inglês e espanhol ${ }^{43}$.

Segundo informações obtidas, em outubro de 2009, no site, http://www.ensinosuperior.sp.gov.br/, a Univesp foi criada pelo decreto $\mathrm{n}^{\circ} 53.536$ de 9 de outubro de 2008 com o objetivo de ampliar o acesso à educação superior pública, em parceria com as três universidades paulistas - USP, a Unicamp e a Unesp - e com o Centro Paula Souza. A estrutura consorciada da Univesp agrega ainda outras instituições, entre elas a Fundação Padre Anchieta, a Fapesp, a Fundap e a Imprensa Oficial. Os cursos oferecidos pela Univesp têm seu projeto acadêmico e seus conteúdos formulados pelas universidades que os propõem. São

\footnotetext{
41 http://uab.capes.gov.br/index.php?option=com content\&view=article\&id=111\&ltemid=27, $\quad$ site visitado em 28 jan. 2009.

$\begin{array}{lll}42 & \text { informações no sisponivel no }\end{array}$ http://www.etecbrasil.mec.gov.br/gCon/recursos/upload/file/Decreto etec(2).pdf site visitado em 28 jan. 2009

${ }^{16}$ Informações disponível no site http://www.ensinosuperior.sp.gov.brl, acesso em 01 out. 2009.
} 
elas também as responsáveis pelo processo de seleção para o ingresso dos estudantes, bem como pela avaliação de seu desempenho nos cursos. À Univesp cabe garantir as condições materiais, financeiras e tecnológicas para a realização desses cursos, acompanhando, de modo integrado com a instituição parceira, a sua realização, o seu desenvolvimento e o aproveitamento dos alunos neles matriculados. O primeiro curso, de graduação em Pedagogia, será oferecido pela UNESP com início em 2010, com 40\% das atividades no modo presencial, em atividades realizadas nos cerca de 30 pólos distribuídos pelo Estado de São Paulo.

\section{Educação a Distância e os meios}

A educação que, inicialmente era oral, sofreu alterações com o surgimento da escrita. Mas não parou por aí, a cada nova tecnologia a educação foi se modificando e curiosamente atendendo um maior número de pessoas.

Na Grécia Antiga, a educação era para um grupo muito restrito de pessoas e "o professor" discursava para seus discípulos. Segundo Otto Peters ${ }^{44}$ Platão criticou a possibilidade do uso da escrita na educação com o argumento que a palavra escrita não pode responder ao aluno.

Mesmo sendo reduzido o número de leitores, a escrita já permitiu que mais pessoas pudessem ter acesso as informações mesmo distante fisicamente dos mestres.

Com o intuito de compreender as relações entre educação e meios de comunicação, faremos uma breve descrição de cada uma das principais mídias.

\section{Prensa Gráfica}

Com o advento da prensa gráfica na Europa, em $1450^{45}$, a divulgação das informações foi mais disseminada ainda. Começaram a surgir diferentes textos para diferentes leitores e a utilização da mídia impressa se deu de maneira diferente em

\footnotetext{
${ }^{44}$ PETERS, OTTO, A Educação a distância em transição - São Leopoldo:UNISINOS, 2004

${ }^{45}$ Data aproximada para a invenção da "prensa gráfica" na Europa, segundo Peter Burke \& Asa Briggs in Uma História social da mídia. Os mesmos autores afirmam que a impressão já era utilizada antes desse período na China e no Japão, mas que não teria se disseminado pois o procedimento era apropriado para ideogramas e não para alfabetos de 20 ou 30 letras.
} 
cada país ou região, de acordo com as necessidades e característica econômicas, sociais e culturais.

Se os manuscritos já permitiam a transmissão de informações entre pessoas geograficamente distantes, a impressão acelerou esse processo se consideramos apenas a agilidade que agora ganhava a produção de materiais escritos.

O trânsito de materiais escritos aumentou a possibilidade de comunicação a distância. Sendo assim, poderíamos dizer que os sistemas de impressão, a partir da prensa gráfica, facilitaram o aparecimento da educação a distância. Concordamos com BURKE \& BRIGGS ${ }^{46}$ quando dizem que as novas técnicas atuam como um catalisador, mais ajudando as mudanças sociais do que as originando, por isso usamos "facilitou" e não "permitiu" ou "originou". Sendo assim, podemos afirmar que a mídia impressa colaborou com o surgimento de uma nova modalidade de educação, diferente da presencial, talvez esperada e desejada em certos contextos.

\section{Telefone}

Embora, num primeiro momento, o telefone não tivesse sido usado em cursos a distância como foi o material impresso, cabe citá-lo, pois foi o sistema de telefonia que deu condições às primeiras comunicações via internet.

\section{Rádio}

Depois da imprensa, em termos midiáticos, a tecnologia que teve grande repercussão em termos educacionais foi a radiodifusão. Experiências com a transmissão de sinais por ondas eletromagnéticas, dispensando o uso de fios como na telegrafia, ocorreram em vários países, inclusive no Brasil com os trabalhos do Padre Landell de Moura ${ }^{47}$, mas a invenção do rádio é convencionalmente atribuída a Guglielmo Marconi, que em 1896 apresentou o rádio à Grã-Bretanha.

\footnotetext{
${ }^{46}$ BURKE, P. \& BRIGGS, A. Uma história social da mídia - Rio de Janeiro: Zahar, 2004

${ }^{47} \mathrm{Em} 1893$, portanto, antes da primeira experiência realizada por Guglielmo Marconi, o gaúcho padre Landell de Moura realizava, em São Paulo, do alto da Av. Paulista para o alto de Sant'Ana, as primeiras transmissões de telegrafia e telefonia sem fio, com aparelhos de sua invenção, numa distância aproximada de uns oito quilômetros em linha reta, entre aparelhos transmissor e receptor, presenciada pelo Cônsul Britânico em São Paulo, Sr. C. P. Lupton, autoridades brasileiras, povo e vários capitalistas paulistanos. Embora sua transmissão radiofônico tivesse acontecido antes da de Marconi, ele só a patenteou em 1901, no Brasil, e, em 1904 nos EUA.
} 
Assim como qualquer outra inovação, o rádio recebeu de elogios à críticas, passando pelo descrédito, mas continua presente, hoje, em nossas vidas. Se considerarmos como características do rádio, por exemplo, o uso da linguagem oral, sua abrangência e mobilidade, é fácil perceber porque ele, apesar de tantos outros veículos de comunicação, continua tendo forte presença.

Ao longo de sua história o rádio sempre foi utilizado com finalidades educativas fossem elas formais ou não formais, a distância ou presenciais. Na educação a distância lembraremos, agora, apenas dois dos já citados exemplos, quando pontuamos algumas das realizações da educação a distância no Brasil, o Projeto Minerva e a Universidade do Ar. Como exemplo do uso educativo não formal e não vinculado ao ensino a distância, podemos citar dois exemplos: o CALA-BOCA JÁ MORREU - porque nós também temos o que dizer!, que objetiva ensinar à jovens e crianças novas linguagens e tecnologias de comunicação por meio de oficinas de jornal impresso, vídeo, internet e rádio; e o Educom.radio, coordenado pela Escola de Comunicação e Artes da Universidade de São Paulo e realizado em parceria com a Secretaria Municipal de educação da Cidade de São Paulo, que objetiva "formar, capacitar e assessorar profissionais da educação e membros da comunidade escolar (educomunicadores) para que explorem e multipliquem as possibilidades de utilização das tecnologias e linguagens das mídias (iniciando com rádio) como instrumentos de promoção da cidadania e da melhoria do ensino." ${ }^{48}$

\section{Televisão}

Da fotografia ao cinema, do cinema à televisão e, eis mais um veículo de comunicação que acaba sendo incorporado pela educação e pela educação a distância. Vejamos, a seguir, algumas possibilidades dos usos da "televisão" e mídias correlatas ${ }^{49}$ na educação a distância.

Com a utilização do sistema de transmissão televisiva deparamos-nos com o conceito de sala de aula a distância. O professor está em um estúdio de televisão "dando uma aula" que é gravada e transmitida. Um exemplo desse modelo é o

48 Informações obtidas no site http://portal.prefeitura.sp.gov.br/secretarias/relacoes internacionais/carteira de projetos/inclusao soc ial/0004, visitado em outubro de 2009.

${ }^{49}$ Correlatas no sentido de usarem os mesmos princípios de transmissão de imagem e som. 
Telecurso, já referenciado anteriormente, que usa os programas televisivos e material impresso em cursos de $1^{\circ}$ e $2^{\circ}$ graus.

Com as novas tecnologias de transmissão digital de imagem e som, temos duas novas versões da sala de aula a distância: a teleconferência e a videoconferência.

$\mathrm{Na}$ teleconferência o sinal de televisão é gerado e transmitido via satélites até os pontos em que estão os alunos e, a recepção do sinal é feita por antenas e decodificadores. A informação transita em via de mão única, isto é, existe apenas um canal de transmissão e, ele não recebe sinais de outros pontos. Já na videoconferência a comunicação é feita em duas vias, isto é, todos os pontos são tanto transmissores como receptores, o que possibilita a interação entre todos os participantes. Normalmente, a interação nas teleconferências se dá por meio da utilização de recursos como fax, telefone ou email.

Quando aluno e professor estão separados fisicamente, mas não no tempo, isto é, os alunos assistem as aulas no momento de sua transmissão temos um comunicação síncrona. Quando professor e alunos estão separados no espaço e no tempo, temos uma comunicação assíncrona.

Como exemplos do uso da televisão e de mídias correlatas na educação, podemos citar o uso de vídeos nas aulas presencias. Se houve várias correntes de educadores que abominaram a televisão, outros desenvolveram e desenvolvem trabalhos interessantes utilizando o vídeo em sala de aula como recurso de ensino e aprendizagem. O vídeo, se bem utilizado, pode trazer enormes vantagens e apenas para ilustrar essa idéia apresentaremos a possibilidade de mostrar para alunos de qualquer nível de ensino conceitos, processos e princípios difíceis de serem ilustrados de outra forma, com exceção do computador que será abordado na seqüência, ou mesmo vivenciado. Estamos falando, por exemplo, de filmes que mostram a reprodução humana, a proliferação de bactérias, etc. As TVS educativas têm produzido materiais excelentes sob esse ponto de vista, permitindo que todos possam ver o que antes era apenas dito. 


\section{Computador}

Seria impróprio afirmar que a educação a distância criou alguma mídia ou que algum meio de comunicação foi criado propositalmente para essa modalidade de ensino. Essa afirmação também é válida para a educação presencial. Não tempos registros que comprovem que qualquer meio de comunicação tenha sido criado com finalidades educacionais e que depois tenham sido incorporados por outros setores da sociedade. O processo foi exatamente no sentido oposto. O que de fato vem acontecendo, ao longo da história, é que a educação, seja ela presencial ou a distância, apropria-se dos recursos midiáticos como instrumentos para os processos de ensino e aprendizagem. E com os computadores não seria diferente.

Foi durante a segunda guerra mundial que surgem os computadores, como os conhecemos hoje. Inicialmente projetados apenas para desenvolveram cálculos e com objetivos estratégicos em termos bélicos. Mas com o fim da guerra passou a ser usado em diversas atividades e com uma variedade enorme de finalidades até chegar ao que foi chamado de máquina de ensinar.

O conceito de máquina de ensinar está associado a teoria Behaviorista, que será trabalhada no próximo capítulo. Mas em suma os adeptos dessa teoria acreditam que os programas de computador poderiam substituir os professores na modelagem do comportamento dos alunos.

A utilização dos computadores em educação nem sempre seguiu caminhos coerentes com a idéia de serem instrumentos facilitadores dos processos de ensino e aprendizagem. No Brasil, por exemplo, na década de noventa, muitas escolas resolveram introduzir o que na época era denominado de "informática educativa".

Definir "informática educativa", não é tarefa fácil, tendo em vista que ela percorreu dois caminhos distintos nas escolas brasileiras. Tivemos escolas, basicamente as de ensino fundamental e médio, que entenderam a "informática educativa" como ensinar "informática" para os alunos. E na maioria das vezes essa era a expectativa 
dos pais que desejavam que seus filhos aprendessem a usar o computador para auxiliá-los. Oferecer aulas de "informática educativa" era, em muitas escolas privadas, usada como sinônimo de modernidade e argumento de marketing. Mas outras instituições de ensino compreendiam que "informática educativa" era um campo de estudos que objetivava utilizar os recursos oferecidos pela informática nos processos de ensino e aprendizagem. Mas os materiais voltados para a educação eram raros, no Brasil, com isso eram utilizados programas de computador (software) que, na sua grande maioria, eram materiais traduzidos, originários, geralmente, dos Estados Unidos.

Um pouco antes de a informática chegar às escolas brasileiras, na década de oitenta, temos, no SENAC de São Paulo, a criação de um grupo de trabalho denominado de PIE (Programa de Informática na Educação) que se caracterizou como um dos primeiros movimentos nacionais a desenvolver software educativo. Do desenvolvimento de software para os cursos que a instituição trabalhava esse grupo, do qual fiz parte, passou também a criar metodologias de ensino e a oferecer cursos para o público em geral. Na década de noventa as atividades do PIE se ampliaram e foi criado o Centro de Tecnologia Educacional (CTE), com atividades na área de vídeo, artes e informática, todas voltadas para o uso das tecnologias de informação e comunicação a serviço da educação. O PIE e o CTE ${ }^{50}$ foram coordenados pelo Prof. Francisco Aparecido Cordão e pelo Prof. Dr. Jarbas Novelino Barato que entre outras contribuições para a educação nacional, colaboraram para que o Brasil tivesse um software educacional no mercado norte-americano, o Divide \& Conquer e fosse parceiro de líderes mundiais no trabalho com vídeos educativos.

Contemporâneos ao PIE, tivemos trabalhos desenvolvidos na Universidade Federal do Rio Grande do Sul (UFRGS) e na Escola Paulista de Medicina. As atividades da UFRGS eram coordenadas pela Profa $\mathrm{Dr}^{\mathrm{a}}$ Lea Fagundes, que objetivavam entre outras coisas levar a informática educativa para os alunos das escolas públicas. As da Escola Paulista de Medicina tinham como idealizador e coordenador o Prof. Dr.

\footnotetext{
${ }^{50} \mathrm{O}$ PIE e o CTE desenvolveram dezesseis softwares educacionais para a plataforma Apple II e; cinco softwares para a plataforma IBM -PC; o PIE ganhou, com o programa "Cálculo de Insulina", o prêmio MEC de melhor software educacional do Brasil; entre outras realizações.
} 
Daniel Sigulen que trabalhava sob a ótica de usar a informática educativa nos cursos de medicina e no desenvolvimento de software para o auxílio de diagnóstico.

Em 1997, por meio da Portaria $n^{\circ}$ 522/MEC, de 9 de abril de 1997, é criado O Programa Nacional de Tecnologia Educacional (Prolnfo), para promover o uso pedagógico de Tecnologias de Informática e Comunicações (TICs) na rede pública de ensino fundamental e médio. São criados núcleos em diversos pontos do Brasil para capacitar e apoiar professores e surgem promessas e projetos no sentido para equipar as escolas públicas com computadores para serem usados pelos alunos. Mas depois de mais de uma década não vimos às promessas cumpridas e ainda nos deparamos com discussões sobre qual computador comprar.

Nesse cenário, podemos dizer que o problema do Brasil não é de tecnologia, mas de desigualdade de oportunidades. Temos políticas educacionais de partidos, mas falta-nos uma política educacional para a nação que objetivem a igualdade de oportunidades em termos educacionais.

A educação a distância usou os computadores basicamente de duas formas, com o CBT (Computer Basead Training) e os livros eletrônicos. O princípio de CBT, que pode ser traduzido como treinamento baseado em computador, foi muito utilizado em empresas que viam a possibilidade de oferecer treinamento, em diversas áreas, aos seus funcionários sem a necessidade de deslocamento físico e o afastamento de seus postos de trabalho. Numa linha bastante semelhante, são criados os materiais multimídia para o ensino de línguas estrangeiras. Já os livros eletrônicos foram basicamente usados em algumas escolas da educação básica que, como o próprio nome diz, apresentavam os mesmos conteúdos dos livros didáticos com o acréscimo de recursos de áudio e às vezes alguns pequenos vídeos.

\section{Internet e a WEB}

Os primórdios da Internet datam da década de sessenta, com a ARPANET, um projeto do governo norte-americano que, inicialmente era voltado para fins militares, mas que com o fim da Guerra Fria foi transferido para as universidades e os centros de pesquisa com o objetivo interligá-los. A Internet, como conhecemos hoje, foi 
sendo construída durante a década de oitenta quando diversas instituições dos EUA e de outros países foram se interligando, criando um grande rede de comunicação sem cunho comercial. Mas foi na década de noventa com a permissão para o uso comercial da Internet é que tivemos seu verdadeiro desenvolvimento. De uma forma bastante simples, podemos dizer que a Internet é uma grande que liga computadores espalhados pelo mundo inteiro. No Brasil a Internet chegou em 1991 por meio da Rede Nacional de Pesquisas com o objetivo de interligar as universidades e centros de pesquisa. Em 1995 os Ministérios de Comunicações e de Ciência e Tecnologia abriram a Internet para a sua operação comercial.

Se no início a Internet oferecia poucos serviços, basicamente o correio eletrônico e a transferência de arquivos, hoje, temos na WEB uma enorme quantidade de recursos que, por exemplo, permite a troca de emails (correio eletrônico), a navegação de forma simples entre páginas, a criação de conteúdos com textos, imagem e áudio. $A$ WEB (WorldWideWeb) também conhecida como www é um sistema de documentos em hipermídia ${ }^{51}$ que são interligados e executados na Internet ou, em outras palavras, é um sistema de informações organizado de maneira a englobar todos os outros sistemas de informação disponíveis na Internet. Por suas características, alguns autores dizem que a web permite a convergência de todas as mídias. É possível, por exemplo, transmitir programas, gravados ou ao vivo, de rádio e TV pela Web. Tais sistemas recebem os nomes de Webrádio e Webtv, respectivamente.

Quando a Internet surgiu para o grande público era moroso conectar um computador a outro; hoje, com o desenvolvimento de novas tecnologias na transmissão de dados, os usuários mal percebem que existe um processo para tal. As pessoas que conheceram e usaram a internet devem ter, ainda, lembranças das dificuldades e instabilidade nas conexões, mas para os mais jovens ter um computador ligado na internet tornou-se algo natural. Com essa afirmação não estamos ignorando as diferenças sócio-econômicas que limitam 0 acesso a essa tecnologia, principalmente, quando pensamos no Brasil.

\footnotetext{
${ }^{51}$ Hipermídia é a fusão de várias mídias a partir de elementos não lineares. Portanto, é diferente de multimídia que se caracteriza pela simples reunião de diferentes mídias.
} 
A educação a distância viu na web uma possibilidade enorme de crescimento e com o aumento do número de usuários da web houve, também, o aumento de cursos a distância espalhados pelo mundo. Com a web a oferta de cursos a distância foi ampliada, por exemplo, há a possibilidade de um brasileiro fazer um curso em uma universidade européia, sem sair do seu país.

A seguir, apresentaremos um quadro síntese das mídias utilizadas em educação a distância e suas características.

\begin{tabular}{|l|l|}
\hline \multicolumn{1}{|c|}{ Mídia } & \multicolumn{1}{|c|}{ Característica } \\
\hline Material impresso & Texto e imagem estática \\
\hline Rádio & Áudio \\
\hline Televisão & Áudio e imagem de forma linear \\
\hline Computador & $\begin{array}{l}\text { Texto, áudio, imagem e não linear, mas sem troca de } \\
\text { informações. }\end{array}$ \\
\hline WEB & $\begin{array}{l}\text { Texto áudio, imagem não lineares, com troca de } \\
\text { informações síncronas ou assíncronas }\end{array}$ \\
\hline
\end{tabular}

Quadro 2 - Mídias utilizadas em EAD

Considerando que, atualmente, é grande o número de meios e tecnologias que podem ser usados em educação a distância, é comum encontrarmos uma confusão entre meio e modalidade. Muitas vezes, as pessoas valem-se do nome do meio para designar a modalidade. Isto é, ao invés de termos a expressão, por exemplo: "educação a distância por correspondência", temos "educação por correspondência." É preciso deixar claro que "a correspondência" é o meio que está sendo utilizado para enviar conteúdos, tarefas, para a comunicação aluno-professor etc., na modalidade a distância de educação e, não é "o tipo de educação" que está sendo ofertado.

Nesse sentido, vimos encontrando expressões como:

E-learning para caracterizar a educação a distância que se vale dos meios eletrônicos de comunicação, mais especificamente, nesse caso, a internet. ${ }^{53}$

\footnotetext{
${ }^{52}$ Falamos de som e imagem de forma linear considerando a TV analógica que temos, com predominância, hoje. A TV digital permite a não linearidade, mas ainda não está definitivamente disponível no Brasil, para a maioria da população.
} 
"Aprendizado assíncrono" para representar às formas de educação a distância em que a comunicação se dá por meio de tecnologias da internet que apóiam as comunicações assíncronas, isto é, que não ocorrem ao mesmo tempo, como email, por exemplo.

"Presencial conectado" para dizer que há encontros presenciais em espaços físicos e tempo determinados para que os alunos, previamente agrupados "assistam" aulas transmitidas para qualquer lugar via satélite ou Internet, com a presença de um instrutor local e apoio de material impresso ${ }^{54}$.

Moore \& Kearsley, 2007, apresentam outra expressão associada à educação a distância como "universidade aberta" ou "aprendizado aberto", como sendo um termo:

Usado na Europa e em outros países com tradição de uma educação superior muito elitista, nos quais, muitas vezes, está relacionada a "educação a distância" no acrônimo "EDA", significando "educação a distância e aberta". A idéia é que a educação a distância possa permitir o acesso ao aprendizado e dar maior autonomia ao aluno. ${ }^{55}$

Acreditamos que seja qual for o nome usado, não podemos perder de vista que estamos falando de educação. Temos, sim, que respeitar a modalidade e as características dos recursos utilizados, mas sem perder o foco no processo educacional.

Diferentes autores organizaram as várias fases da educação a distância, no que se convencionou chamar de "gerações de EAD". Como não há um consenso do que caracterizaria todas as etapas, com exceção da primeira e segunda geração, a seguir apresentaremos um quadro síntese do que julgamos ser uma das possíveis organizações.

\section{A seguir apresentaremos um quadro síntese das gerações de EAD}

\footnotetext{
${ }^{53}$ Otto Peters usa o termo "educação a distância baseado na rede", ao se referir a e-learning, Curiosamente as empresas que usam o termo e-learning e ao se referirem as ações voltadas para a educação coorporativa em lugar da "educação a distância".

${ }^{54}$ No Brasil essa expressão tem sido usada pela Universidade do Norte do Paraná (UNOPAR).

${ }^{55}$ MOORE, M.; KEARSLEY,G. Educação a distância: uma visão integrada. São Paulo: Thomson Learning, 2007.
} 


\begin{tabular}{|l|l|}
\hline Geração & Recursos ou mídias \\
\hline $1^{\text {a }}$ Geração & $\begin{array}{l}\text { Material Impresso - ensino por } \\
\text { correspondência }\end{array}$ \\
\hline $2^{\text {a }}$ Geração & $\begin{array}{l}\text { Material Impresso, rádio e televisão - } \\
\text { rádioeducação e teleducação }\end{array}$ \\
\hline $3^{\text {a Geração }}$ & $\begin{array}{l}\text { Computadores - educação assistida por } \\
\text { computadores }\end{array}$ \\
\hline $4^{\text {a }}$ Geração & WEB - educação on-line, e-learning. \\
\hline
\end{tabular}

Quadro 3 - Gerações da EAD

\section{Modelos e finalidades da educação a distância}

Em seu livro Educação a distância em transição ${ }^{56}$, Otto Peters apresenta sete modelos que caracterizam as finalidades com que se promove a educação a distância. São eles: preparação para exames; educação por correspondência; multimídia; educação a distância em grupo; aluno autônomo; educação a distância baseado na rede e, por fim a sala de aula tecnologicamente estendida.

O autor afirma que muitos profissionais negam a existência do modelo "preparação para o exame", mas ele existe e é importante em termos da compreensão dessa modalidade a distância de ensino. Esse modelo, tem por objetivo preparar os alunos para os exames e, foi institucionalizado em meados do século XIX quando a Universidade de Londres se limitava a informar aos interessados qual material deveria ser lido e o regulamento dos exames. Nesse modelo o aluno deve estudar sozinho. Além da experiência londrina, Otto Peters cita a existência desse modelo na China. Nesse modelo podemos perceber que a preocupação máxima é com o exame e com a provável certificação que os aprovados obteriam.

A educação por correspondência, segundo Peters, é o modelo mais antigo e mais utilizado e nas suas palavras:

é o modelo de "preparação para exame" mais o ensino regular, apresentando textos didáticos escritos ou impressos, tarefas, correção e

\footnotetext{
${ }^{56}$ PETERS, OTTO. Educação a distância em transição. São Leopoldo: Unisinos, 2003.
} 
correspondência regular ou ocasional entre a instituição de ensino e os estudantes.

Embora algumas pessoas julguem esse modelo como ultrapassado se comparado com os atuais recursos tecnológicos, muitas instituições ainda o utilizam. Podemos citar o Instituto Monitor, no Brasil e a École Universelle, na França. Esse modelo representa a primeira geração da educação a distância.

No modelo multimídia são utilizados o rádio, a televisão e o material impresso para a apresentação do curso estruturado pré-preparado aos alunos, que podem ainda contar ou não com apoio presencial em espaços físicos determinados. No Brasil, esse modelo pode ser representado pelo Telecurso ${ }^{57}$, quando do seu início em meados da década 70 .

O modelo de "educação a distância em grupo" reúne um grupo de alunos que assistem às aulas transmitidas por rádio ou televisão. Normalmente, os grupos são acompanhados por um instrutor e depois de assistirem as aulas fazem suas tarefas. Segundo o autor, a universidade Central por Rádio e Televisão chinesa é o exemplo mais proeminente desse modelo. No Brasil, entendemos que a Universidade do Norte do Paraná (Unopar), já citada anteriormente, pode ser considerada um exemplos nesse tipo de educação a distância.

Já no modelo ao "aluno autônomo" quem determina o que e como vais estudar é o próprio aluno, ele é responsável inclusive pela mensuração do êxito de seu aprendizado. Os professores atuam como orientadores pessoais, que se encontram periodicamente com os alunos. Há um contrato entre professor-aluno e universidade em que são definidas as obrigações e direitos de cada parte. Além disso, o aluno é encorajado a buscar em outros locais, além da universidade, informações e conteúdos que podem contribuir para o seu estudo. Segundo Peters (2003), na literatura, esta forma de educação a distância é denominada de "aprendizagem por contrato".

\footnotetext{
${ }^{57}$ Telecurso: programas voltados para o Ensino Fundamental em Médio, transmitidos por sinal de televisão aberta com apóio de material impresso. Os participantes do curso podem prestar exames organizados pelos sistemas estaduais de educação para a obtenção das respectivas certificações.
} 
O modelo de educação a distância baseado na rede utiliza os recursos da informática e da web para que o aluno tenha a cesso aos mais diferentes materiais e recursos didáticos. Podem, ainda, "conversar com professores e colegas por meio de emails, chats ou videoconferência." O aluno, normalmente, estuda sozinho.

Por fim, a sala de aula estendida tecnologicamente utiliza satélites ou outros meios de videoconferência para transmitir para diferentes locais uma aula que está sendo realizada para um determinado grupo de alunos em tempo e espaço definidos. Podemos dizer que esse modelo é muito próximo ao da "educação a distância em grupo", apresentando como diferença apenas o recurso tecnológico utilizado.

Ao analisar os modelos definidos por Peters (2004), entendemos que há um equívoco quando ele classifica "preparação para exames" como modelo e não como "finalidade", uma vez que podemos oferecer cursos a distância com a intenção de preparar alguém ou várias pessoas para um exame em todos os modelos descritos por ele, como, por exemplo, sala de aula tecnologicamente estendida ou por meio de programas de televisão especialmente feitos para isso.

Sendo assim, concluímos que os modelos apresentados por Peters referem-se mais aos recursos utilizados para a realização da modalidade a distância do que suas finalidades propriamente ditas.

A partir dessa constatação, propomos as categorias descritas abaixo, para classificar os modelos de educação em função de seus objetivos e finalidades. São elas:

a) Preparação para exames

b) Cursos livres

c) Cursos coorporativos

d) Cursos regulares

Na categoria "preparação para exames", concordamos na íntegra com a definição de Otto Peters, quando ele diz que a finalidade é preparar as pessoas para um exame seja ele para obtenção de um certificado do ensino fundamental ou de um ensino 
técnico. Mas ressaltamos uma diferença, hoje, ela pode se valer de quaisquer mídias e não exclusivamente a mídia impressa.

Os cursos livres não têm vínculo e nem se submetem às regras estabelecidas pelo Ministério da Educação e Cultura ou das Secretarias de Educação dos Municípios ou Estados, não tem obrigatoriedade de carga horária, tempo de duração, ou exigência em termos de formação ou conhecimento prévio. Os exemplos mais conhecidos são os cursos de idiomas e informática, mas uma variedade enorme de títulos vêm sendo oferecidos, atualmente. Tais cursos têm como finalidade a busca de conhecimento em uma determinada área, sem a preocupação com a certificação.

Os cursos coorporativos têm como finalidade atender a demandas específicas das empresas. São cursos que objetivam capacitar, especializar ou treinar um determinado grupo de funcionários em uma tarefa ou habilidade. A partir desse tipo de curso surgiram as universidades coorporativas com os mesmos objetivos dos cursos. Tanto cursos como as universidades coorporativas não estão sujeitas as regulamentações a legislação educacional brasileira.

Chamamos de cursos regulares aqueles que têm legislação própria estabelecida pelo Ministério da Educação e Cultura e pelas Secretarias de Educação dos Estados e Municípios. Podem ser classificados como cursos regulares os de ensino fundamental e médio, os de educação profissional, os superiores e os de pósgraduação. A finalidade de cada um dos cursos regulares está estabelecida na Lei de diretrizes e Bases da educação Nacional, de 1996 (LBD n 9394), podendo se oferecido na modalidade presencial ou a distância.

Dos cursos regulares, neste trabalho a atenção estará voltada, principalmente, serão os cursos de graduação, no que diz respeito a avaliação da aprendizagem.

A proposição dessas quatro categorias: preparação para exames, cursos livres, cursos coorporativos e cursos regulares, permite identificar as finalidades de um curso a distância com mais precisão. 
Quando pretendemos oferecer um curso a distância ou, quando temos intenção de sermos aluno de um curso nessa modalidade é importante conhecer as diferentes denominações, comparar características, vantagens, desvantagens e exigências de cada modelo. No entanto, quando o objetivo é conhecer quais são os pressupostos relativos a avaliação da aprendizagem que sustentam um curso a distância, essa classificação pouco ajuda, pois ela define operacionalmente como as informações são transmitidas, que mídias são utilizadas, encontros entre professor e aluno, mas não falam o que entendem por aprender e ensinar.

Nesse sentido, Aretio em seu livro De la educación a distancia a la educación virtual $^{58}$, apresenta um modelo baseado no que ele chama de "correntes pedagógicas", mas que intencionalmente não teceremos, neste momento, nenhum comentário, pois o tema “concepções pedagógicas" será abordado no próximo capitulo.

\section{Panorama atual}

Segundo dados do Censo de 2008, realizado pelo Instituto Nacional de Estudos e Pesquisas Educacionais Anísio Teixeira (INEP), o setor Privado foi o maior ofertante de vagas para cursos de graduação a distância, no Brasil, como mostra a tabela abaixo ${ }^{59}$, considerando que o setor público compreende as Universidades, CEFETS e IFETS.

\begin{tabular}{|l|c|c|c|}
\cline { 2 - 4 } \multicolumn{1}{c|}{} & $\begin{array}{l}\text { Vagas } \\
\text { oferecidas }\end{array}$ & $\begin{array}{l}\text { Matrículas } \\
\text { on/06 }\end{array}$ & Concluintes \\
\hline Universidades Públicas & 251.821 & 275.896 & 8.175 \\
\hline Universidades Privadas & 1.211 .422 & 309.380 & 32.542 \\
\hline Centros Universitários & 97.637 & 35.191 & 7.462 \\
\hline $\begin{array}{l}\text { Faculdades - Escolas } \\
\text { Institutos }\end{array}$ & 135.953 & 104.402 & 21.889 \\
\hline CEFET - IFET & 2.656 & 3.092 & \\
\hline Total Brasil & 1.699 .489 & 727.961 & 70.068 \\
\hline
\end{tabular}

Quadro 4 - Oferta de EAD

\footnotetext{
${ }^{58}$ ARETIO, L.G. De la educación a distancia a la educación virtual. Barcelona: Ariel, 2007.

${ }^{59}$ Fonte INEP
} 
Com exceção da região Norte do país, onde a maior oferta é feita pelo setor público, em todas as outras regiões o setor privado é quem mais oferece vagas em cursos de graduação a distância.

Segundo o relatório do INEP:

De acordo com os dados do Censo, 115 instituições ofereceram, em 2008 ,
cursos de graduação a distância. São 18 IES a mais em relação às
registradas no ano de 2007 . É possível observar que o número de cursos de
graduação a distância aumentou de maneira significativa nos últimos anos.
Comparado ao ano de 2007 , foram criados 239 novos cursos,
representando um aumento de $58,6 \%$ no período. O número de vagas
oferecidas em 2008 registrou um aumento de $10,3 \%$, ou seja, uma oferta de
158.419 vagas a mais. O crescimento no número de vagas da educação a
distância deu prosseguimento a um aumento que se observa desde 2003 .
Nesse período registrou-se uma variação de mais de 70 vezes no número
de vagas ofertadas.

Segundo o mesmo relatório destaca-se ainda:

- O fato de que o número de matrículas, em 2008 , foi $42,2 \%$ maior do que em 2007;

- O número de matrículas em cursos a distância representa $14,3 \%$ do total das matrículas dos cursos de graduação;

- A quantidade de concluintes em educação a distância também apresentou um forte aumento de $135 \%$ em relação ao ano de 2007 ;

São números expressivos se considerarmos a curta história da educação a distância no Brasil quando falamos de cursos regulares e com a mesma validade dos cursos presenciais, mas eles nada dizem sobre a qualidade desses cursos. E, como, bem afirmam Gatti e Barreto ${ }^{61}$, "são ainda raras as pesquisas que se debruçam sobre os problemas e desafios postos pela expansão de EAD e pelas novas dimensões que ela vem assumindo no país, o que é compreensível, de certo modo, tendo em conta o seu caráter recente", fato que reitera nosso interesse nesta pesquisa.

\footnotetext{
60 Informações disponível no site http://www.inep.gov.br/imprensa/noticias/censo/superior/news09 05.htm, aceso em 01 nov. 2009.

${ }^{61}$ GATTI, B. A. \& BARRETO, E. de Sá. Professores do Brasil: impasses e desafios. UNESCO Brasil , 2009.
} 


\section{MARCO METODOLÓGICO}

A pesquisa a ser realizada insere-se no campo da pesquisa qualitativa, por meio da análise documental $^{\mathrm{i} 62}$. De acordo com Martins \& Bicudo ${ }^{63}$ a pesquisa qualitativa apresenta características fundamentais, como as que seguem:

- A pesquisa qualitativa busca uma compreensão ${ }^{64}$ particular daquilo que estuda, não se preocupando com generalizações, princípios e leis.

- A investigação objetiva a compreensão e não a explicação

- A metodologia da pesquisa qualitativa deve ser de natureza teórica e prática concomitantemente.

- A pesquisa qualitativa é descritiva. As descrições são tratadas interpretativamente.

e, segundo: Bogdan \& Biklen 65

- A análise dos dados tende a se dar de forma indutiva. Os dados não são recolhidos com o objetivo de testar hipóteses ou de responder questões prévias. As abstrações vão sendo construídas ao longo da análise dos dados.

- O significado é de importância vital na abordagem qualitativa.

Para Ludke e André ${ }^{66}$, a análise documental constitui uma técnica importante na pesquisa qualitativa, seja complementando informações obtidas por outras técnicas, seja desvelando aspectos novos de um tema ou problema.

Os documentos legais deveriam, em tese, nortear as ações educacionais, mas eles podem revelar concepções subjacentes nem sempre compreendidas.

Consideramos ainda que todo e qualquer documento representa a intenção do seu autor e, portanto, não deve ser encarado como uma descrição neutra. Por outro

\footnotetext{
${ }^{62}$ Consideramos a origem do termo documento, a partir do Dicionário Aurélio: - do latim documentum, de docere e: aquilo que ensina ou serve de exemplo ou prova ensinar, mostrar; ou por extensão "Toda base de conhecimento fixado materialmente e suscetível de ser utilizado para consulta, estudo ou prova"

${ }^{63}$ MARTINS, J. e BICUDO, MARIA A. VIGGIANI A Pesquisa qualitativa em Psicologia: fundamentos e recursos básicos. São Paulo: EDUC, 1989

${ }_{64}$ Compreensão entendida como uma capacidade própria de o homem compreender.

${ }^{65}$ BOGDAN, R.C.; BIKLEN, S.K. Pesquisa qualitativa em educação. Porto Alegre: Mediação, 1999.

${ }^{66}$ LUDKE, M. e ANDRÉ, Marli E. D. A. Pesquisa em Educação: abordagens qualitativas.

São Paulo: Ed. Pedagógica e Universitária, 1986.
} 
lado, o significado atribuído ao documento também depende do leitor. Nesse sentido, a pesquisa qualitativa mostra-se pertinente para o nosso trabalho, uma vez que não fomos procurar nos documentos a comprovação de hipóteses, mas sim compreender qual o conceito de avaliação se faz presente na legislação para o ensino na modalidade a distância.

Utilizamos como fontes de pesquisa legislações e normas, bem como Projetos Pedagógicos ou outros documentos de Instituições Privadas e Públicas que estejam realizando, ou realizaram a partir de 1996 cursos de Educação a Distância no nível superior. Portanto, trabalharemos a partir de fontes escritas, primárias e secundárias. ${ }^{67}$

Inicialmente buscamos nos sítios do Ministério da Educação e Cultura a legislação referente a Educação a Distância. E, a partir de uma primeira análise, percebemos a importância de ampliar o campo de pesquisa para além da legislação referente a Educação a distância Isto é, fomos procurar compreender, também na legislação e no sítio do Ministério, o conceito de avaliação da aprendizagem em outras modalidades de ensino diferentes da distância.

Além disso, essa análise determinou que a legislação a ser analisada seria a estabelecida a partir da Lei de Diretrizes e Base da Educação Nacional de 1996, tendo em vista que a Educação a Distância no Brasil, só ganhou o status de oferta regular de ensino, após sua promulgação.

Analisamos o conteúdo de cada texto da legislação para decifrar as informações que servissem ao propósito da pesquisa. Essa etapa consistiu num processo de codificação, interpretação e de inferências sobre as informações contidas nas publicações, procurando desvelar seu conteúdo manifesto e latente.

Identificamos assim, unidades de significado que sistematizaram as diferentes aplicações e usos do ter "avaliação", que a seguir se constituíram em "categorias"

\footnotetext{
${ }^{67}$ Fontes primárias: dados obtidos de documentos; Fontes secundárias: dados obtidos de livros, revistas, jornais, publicações avulsas e teses, cuja autoria é conhecida.
} 
que, de acordo com a temática, delinearam os assuntos subjacentes ao estudo. Conforme apontam Lüdke e André (1986), as categorias devem explicitar os propósitos da pesquisa e, ao mesmo tempo, ser internamente homogêneas, externamente heterogêneas, coerentes e plausíveis (1986, p. 43).

Após ter realizado a análise dos documentos legais, analisamos Projetos Pedagógicos de Instituições e outros documentos, que oferecem cursos a distância no nível superior. Quando da impossibilidade de acesso aos referidos projetos, consideramos outros documentos que objetivam caracterizar e explicitar o funcionamento dos cursos em questão.

O procedimento metodológico para a análise dos Projetos pedagógicos foi o mesmo utilizado para a análise da legislação. 


\section{ANÁLISE E TRATAMENTO DOS DADOS}

Nesse momento analisaremos a legislação nacional para identificar quais são as orientações legais sobre avaliação da aprendizagem em cursos à distância.

Queremos investigar se há e qual é a concepção teórica que subsidia tais orientações.

Analisamos os documentos legais a partir da Lei de Diretrizes e Base da Educação Nacional de 1996, pois é a partir dela que a educação a distância ganha o status de oferta regular de prestação educacional em nosso país.

Iniciamos com a intenção de estudar apenas a legislação, no entanto no decorrer do trabalho encontramos o documento "Indicadores de qualidade para cursos de graduação à distância" e, resolvemos inseri-lo como objeto de estudo por se tratar de um documento oficial do ministério da educação e por ser um dos poucos documentos nessa área.

Segundo Juliane Corrêa $(2005){ }^{68}$, os primeiros movimentos de educação à distância no mundo acontecem no séc. XIX nos Estados Unidos e na Europa. No Brasil, os primeiros registros de educação à distância datam 1923 com trabalhos desenvolvidos pela Fundação Roquete Pinto - Radiodifusão e Rádio Sociedade do RJ, e, desde então são inúmeras as iniciativas e as instituições que praticam da educação à distância. No entanto, a legislação brasileira não tratava de modo adequado essa modalidade de ensino e as publicações existentes pertencem às entidades que trabalhavam com EAD, não tendo, assim, nenhum caráter legal ou oficial.

Em 1971 com a promulgação das Leis de diretrizes e bases (Lei $n^{\circ}$. 5692), é atribuído à educação à distância o caráter "experimental". Defini-se, também, que seu funcionamento aconteceria a título precário, ficando sujeito a pareceres dos Conselhos Federal e Estadual de Educação (Art.2 - § 2 da Lei).

\footnotetext{
${ }^{68}$ RIO DE JANEIRO. Senac. Material do curso de Educação a distância pós-graduação Lato Sensu do SENAC. Rio de Janeiro, 2005. CD-ROM.
} 
A EAD começa a receber mais atenção em termos legais, ganhando status oficial a partir da LDB $n^{\circ}$. 9394/96, deixando de ter caráter experimental, pelo menos em termos legais, para ser considerada alternativa regular de ensino.

Segundo Roberto Fragale Filho ${ }^{69}$ os formuladores da política pública educacional do país se viram forçados a elaborar, aprovar e implementar propostas legislativas para o setor porque:

sob o impacto de uma verdadeira revolução tecnológica a Educação a Distância (EAD) conheceu, na esteira da forte expansão do ensino superior havida na segunda metade de 1990 e da pequena regulamentação existente, um impressionante crescimento. Vista com desconfiança, tratada como uma forma supletiva ou complementar do ensino presencial, ela foi quase sempre ignorada nas preocupações legislativas relativas à regulamentação da educação no Brasil. No entanto, com o surgimento de novas tecnologias, rompem-se as barreiras que tornam sua ampliação possível, proporcionando um aumento de oferta sem precedentes e introduzindo sua regulamentação na agenda legislativa.

Destacaremos e apresentaremos a análise de trechos dos documentos oficiais que falam sobre a avaliação da aprendizagem em EAD. Os documentos trabalhados foram:

- Lei $n^{\circ} .9 .394$, de 20 de dezembro de 1996 (artigo 80).

- Decreto $n^{\circ} .2494$ de 10 de fevereiro de 1998.

- Portaria MEC nº 301 de sete de abril de 1998

- Portaria MEC n. 2253 de 18 de dezembro de 2001

- Portaria MEC n . 4.059, de 10 de dezembro 2004.

- Decreto n. 5622, de 19 de dezembro de 2005.

- Referenciais de qualidade para cursos de graduação à distância ${ }^{70}$

\section{Lei $\mathrm{n}^{\circ}$. 9.394, de 20 de dezembro de 1996.}

O artigo 80 da Lei $n^{\circ}$. 9.394, de 20 de dezembro de 1996, traz algumas determinações sobre quem pode oferecer EAD e aponta a forma de criação de mecanismos de controle. Na LDB não encontramos a definição de EAD, ela é

\footnotetext{
${ }^{69}$ Fragale Filho, Roberto - Educação a distância: análise dos parâmetros legais e normativos, DP\&@editora, 2003

${ }^{70}$ Apesar desse documento não ter o caráter legal de uma lei, decreto ou portaria, julgamos pertinente sua inserção na análise por ser tratar de um referencial importante para a EAD por ser um documento oficial.
} 
oficializada no art. $1^{\circ}$ do Dec.2494/98, já referenciado, neste trabalho, como uma das definições que orientariam nossos estudos.

Não há nada explícito em relação à avaliação da aprendizagem. Os pontos mais próximos a essa questão falam que "caberá à União regulamentar requisitos para realização de exames para registro de diplomas relativos a cursos de educação a distância" e também que:

As normas para produção, controle e avaliação de programas de educação à distância e a autorização para sua implementação caberão aos respectivos sistemas de ensino, podendo haver cooperação e integração entre os diferentes sistemas.

Notamos que o termo avaliação refere-se à "a avaliação de programas" e não da aprendizagem. E o termo "exame" que poderia ter alguma proximidade com o nosso tema de pesquisa, transmite-nos uma idéia mais burocrática e administrativa em termos de registro de diplomas, do que uma referência à avaliação de aprendizagem.

\section{Decreto $n^{\circ} .2494$ de 11 de fevereiro de 1998}

Como expresso na sua ementa, "regulamenta o Art. 80 da lei $n^{\circ}$. 9.394, de 20 de dezembro de 1996, e dá outras providências" e, como já dissemos, é nesse decreto que se oficializa a definição de educação à distância, depois da LDB de 1996.

Nesse decreto há algumas referências à avaliação, como no Art. 7

E, o Art. 8

A avaliação do rendimento do aluno para fins de promoção, certificação ou diplomação, realizar-se-á no processo por meio de exames presenciais, de responsabilidade da Instituição credenciada para ministrar o curso, segundo procedimentos e critérios definidos no projeto autorizado

Parágrafo único - Os exames deverão avaliar as competências descritas nas diretrizes curriculares nacionais, quando for o caso, bem como conteúdos e habilidades a que cada curso se propõe a desenvolver

$\S 2^{\circ}$ Os exames dos cursos de educação profissional devem contemplar conhecimentos práticos, avaliados em ambientes apropriados.

$\S 3^{\circ}$ Para exame dos conhecimentos práticos a que refere o parágrafo anterior, as Instituições credenciadas poderão estabelecer parcerias, convênios ou consórcios com Instituições especializadas no preparo profissional, escolas técnicas, empresas e outras adequadamente aparelhadas. 
No artigo sete, a avaliação diz respeito ao que o legislador chama de "rendimento" e não da aprendizagem sctrictu senso, mas podemos considerar como sendo a avaliação da aprendizagem porque em alguns momentos da legislação educacional do Brasil vemos o termo "rendimento" como o que hoje se aproximaria de aprendizagem. No entanto, o texto é claro quando diz que essa avaliação será usada "para fins de promoção, certificação ou diplomação", não existindo nenhuma menção para a aprendizagem em si.

Além disso, outro ponto chama a atenção. A legislação define que os procedimentos e critérios de avaliação serão definidos pela Instituição que oferece o programa. Mesmo que o projeto passe por um processo de autorização, não ficam delineados quais requisitos serão considerados e nem se eles contemplarão ou como a considerarão avaliação da aprendizagem.

Tal constatação remete-nos a duas hipóteses: ou a legislador não quis se comprometer com questões relativas à avaliação da aprendizagem, ou não há uma compreensão da importância desse item nos processos educacionais.

O legislador não faz diferenciação entre os cursos da modalidade presencial e os da modalidade a distância quando diz, no parágrafo único do art.7 que "os exames deverão avaliar as competências descritas nas diretrizes curriculares nacionais quando for o caso, bem como conteúdos e habilidades a que cada curso se propõe a desenvolver". Isto é, que em relação às diretrizes relativas a competências, habilidades e conteúdos os cursos a distância e presencial devem seguir as mesmas diretrizes. No entanto, quando afirma que as competências serão avaliadas nos exames, isso leva-nos a entender que a avaliação ou as avaliações serão realizadas, exclusivamente, em momentos pontuais e específicos, o que não condiz com uma proposta educacional que visa desenvolver competências.

No Art. 8, o termo avaliação está presente novamente, mas sem referências a uma concepção de base. Ele aparece no sentido de orientar os procedimentos operacionais da sua realização. 


\section{Portaria MEC $\mathrm{n}^{\circ} .301$ de sete de abril de 1998}

Dispõe sobre o Credenciamento de Instituições para oferta de cursos de graduação e educação profissional tecnológica a distância e, em nenhum de seus artigos refere-se à avaliação da aprendizagem.

\section{Portaria MEC $n^{\circ} .2253$ de 18 de dezembro de 2001}

Regulamenta a oferta de disciplinas sob a modalidade não presencial em cursos de ensino superior reconhecidos e, no Art. $1 \S 3^{\circ}$ define que :

"Os exames finais de todas as disciplinas ofertadas para integralização de cursos superiores serão sempre presenciais.".

Mais uma vez aparece a idéia de "exame", com a conotação de uma avaliação da aprendizagem como um momento pontual e no final do curso, literalmente. Mas nessa Portaria, no referido artigo aparece a obrigatoriedade de "exames" presenciais na educação a distância.

\section{Portaria MEC $n^{\circ} .4 .059$, de 10 de dezembro 2004.}

Revoga a Portaria $n^{\circ} .2253$ e, dela difere apenas quanto à necessidade de autorização para oferta de disciplinas à distância, parcial ou integralmente, em cursos superiores.

\section{Decreto $n^{\circ} .5622$, de 19 de dezembro de 2005.}

Em seu Art. 1ํ define educação a distância "como modalidade educacional na qual a mediação didático-pedagógica nos processos de ensino e aprendizagem ocorre com a utilização de meios e tecnologias de informação e comunicação, com estudantes e professores desenvolvendo atividades educativas em lugares ou tempos diversos." Já no parágrafo primeiro do mesmo artigo, temos que:

“§ 1ํ A educação a distância organiza-se segundo metodologia, gestão e avaliação peculiares, para as quais deverá estar prevista a obrigatoriedade de momentos presenciais para:

I - avaliações de estudantes;

II - estágios obrigatórios, quando previstos na legislação pertinente; 
III - defesa de trabalhos de conclusão de curso, quando previstos na legislação pertinente; $\mathrm{e}$

IV - atividades relacionadas a laboratórios de ensino, quando for o caso."

Podemos ver que esse decreto reconhece que existem especificidades metodológicas, de gestão e de avaliação na modalidade EAD. No entanto, apesar de reconhecer as "necessidades peculiares" não as define ou explicita, Como nos documentos anteriores, ele limita-se a definir a obrigatoriedade de avaliações presenciais, sem nenhuma justificativa para essa exigência.

No entanto, a nosso ver, tal decreto já avança, de forma positiva, em termos de diretrizes para avaliação da aprendizagem quando inclui na avaliação do desempenho do estudante o "cumprimento das atividades programadas", como disposto no Art. $4^{\circ}$

\footnotetext{
A avaliação do desempenho do estudante para fins de promoção, conclusão de estudos e obtenção de diplomas ou certificados dar-seá no processo, mediante:

I - cumprimento das atividades programadas; e

II - realização de exames presenciais.
}

A inserção do "cumprimento das atividades programadas", para nós, significa um indício da preocupação da avaliação como algo processual e não apenas pontual. Vemos nesse artigo uma primeira e talvez única manifestação com relação mais próxima de uma avaliação que pode estar relacionada à aprendizagem e não apenas à "certificação".

Se de um lado nos pareceu ter havido um avanço em termos legais, logo a seguir enxergamos um retrocesso, quando no parágrafo segundo do mesmo Artigo, o legislador atribui valores diferentes entre os dois meios de avaliação: "cumprimento das atividades programadas" e, realização de "exames presenciais, priorizando este último, como se vê a seguir: " $\$ 2$ O Os resultados dos exames citados no inciso II deverão prevalecer sobre os demais resultados obtidos em quaisquer outras formas de avaliação a distância." 
Quais seriam as motivações e as concepções sobre a avaliação da aprendizagem que priorizam "exames" pontuais em detrimento de um conjunto de atividades, que, segundo os estudos mais recentes sobre o tema defendem a avaliação como algo processual e contínuo? Não considerar tudo o que vem sendo produzido em termos de avaliação da aprendizagem em cursos a distância é no mínimo um contra senso. Temos ainda um fator que nos chama a atenção. $O$ que o autor entende ou quis dizer com "prevalecer"? Seria um peso maior, em sistema de média ponderada? 0 seria desconsiderar "a aprovação nas avaliações a distância se o aluno fosse reprovado no exame presencial? $\mathrm{Na}$ impossibilidade de esclarecer a intenção do autor, só nos resta levantar as prováveis interpretações. De qualquer forma, entendemos que existe nesse Decreto uma enorme possibilidade de que cada instituição de ensino interprete a lei da forma que melhor lhe convier.

Um dos pressupostos que pode ter motivado os legisladores seria o da garantia de autoria. Isto é, se o aluno faz um teste ou qualquer outro tipo de avaliação pontual em casa, ou longe das vistas do professor, como é possível assegurar que foi ele, de fato, quem fez? A busca de resposta para tais indagações poderia ser objeto de outras pesquisas, já que o foco desse trabalho limita-se a identificar as formas de apresentação das questões sobre avaliação da aprendizagem, em EAD, presentes na documentação legal.

No Artigo 13 do decreto em estudo, encontramos mais uma referência sobre a avaliação da aprendizagem que nos passa uma sensação de avanço em termos legais, uma vez que é citada claramente a obrigatoriedade, nos planos pedagógicos dos cursos à distância, da definição do sistema de avaliação do estudante.

Art. 13. Para os fins de que trata este Decreto, os projetos pedagógicos de cursos e programas na modalidade a distância deverão:

I - obedecer às diretrizes curriculares nacionais, estabelecidas pelo Ministério da Educação para os respectivos níveis e modalidades educacionais;

II - prever atendimento apropriado a estudantes portadores de necessidades especiais; 
III - explicitar a concepção pedagógica dos cursos e programas a distância, com apresentação de:

a) os respectivos currículos;

b) o número de vagas proposto;

c) o sistema de avaliação do estudante, prevendo avaliações presenciais e avaliações a distância; $e$

d) descrição das atividades presenciais obrigatórias, tais como estágios curriculares, defesa presencial de trabalho de conclusão de curso e das atividades em laboratórios científicos, bem como o sistema de controle de freqüência dos estudantes nessas atividades, quando for o caso.

Da mesma forma que nos documentos vistos anteriormente, não temos indícios de que critérios serão utilizados pelos representantes legais para avaliar o que for proposto nos diferentes projetos pedagógicos institucionais.

\section{Referenciais de qualidade para cursos de graduação a distância}

Apesar desse documento não ter poder legal, fato reconhecido no próprio texto do documento, optamos por fazê-lo objeto de estudo nesse trabalho por ser um dos poucos referenciais oficiais sobre EAD, atualmente, visto que tem a chancela do Ministério da Educação.

A seguir, destacaremos alguns trechos que julgamos relevantes para o nosso trabalho.

Em um de seus itens, os autores dos indicadores estabelecem como "dever" da instituição que oferece cursos à distância:

\footnotetext{
garantir que os estudantes tenham sua evolução e dificuldades regularmente monitoradas e que recebam respostas rápidas a suas perguntas bem como incentivos e orientação quanto ao progresso nos estudos.
}

Entendemos, nessa orientação, a proposta de avaliação contínua da aprendizagem, mesmo sabendo que para alguns o termo "monitorar" possa ter uma conotação de controle e não de acompanhamento e ajuda no sentido de facilitar a aprendizagem. 
Para nós, sugere um acompanhamento permanente do desenvolvimento e aprendizagem dos alunos.

Logo a seguir encontramos que é preciso:

detalhar nos materiais educacionais que competências cognitivas, habilidades e atitudes o aluno deverá alcançar ao fim de cada unidade, módulo, disciplina, oferecendo-lhe oportunidades sistemáticas de autoavaliação.

Esse parágrafo introduz um elemento novo que é a auto-avaliação, que em nenhuma outra fonte havia aparecido. Ressaltamos que esse elemento ajuda a começar a delinear uma concepção de avaliação de aprendizagem.

Na educação a distância, o modelo de avaliação da aprendizagem do aluno deve: considerar seu ritmo e ajudá-lo a desenvolver graus ascendentes de competências cognitivas, habilidades e atitudes, possibilitando-lhe alcançar os objetivos propostos, conforme indicado no item um deste documento.

Aqui aparece um elemento novo, que trata do reconhecimento de diferentes ritmos de aprendizagem. O estudante é reconhecido como um ser único e, como tal, tem suas próprias condições de aprendizagem, o que necessariamente envolve a avaliação da aprendizagem. Parece que essa parte do texto quer nos dizer que a avaliação não deve ser feita em momentos pontuais para dizer se o aluno está aprovado ou não, se tem ou não direito a um certificado. A avaliação é um dos instrumentos para a aprendizagem e deve servir, entre outras coisas, como elemento para que os professores organizem, ou melhor, dizendo, reorganizem as atividades educacionais com o objetivo de propiciar reais condições de aprendizagem.

Mais que uma formalidade legal, a avaliação deve permitir ao aluno sentirse seguro quanto aos resultados que vai alcançando no processo de ensino-aprendizagem. A avaliação do aluno feita pelo professor deve somar-se à auto-avaliação, que auxilia o estudante a tornar-se mais autônomo, responsável, crítico, capaz de desenvolver sua independência intelectual.

Enxergamos nesse trecho uma crítica velada ao enunciado em documentos legais, já vistos nesse trabalho, quando evidencia que a avaliação é mais que "uma 
formalidade legal". Aqui vemos a avaliação como ferramenta de feedback para o aluno e para o professor.

Além disso, nesse trecho vimos associada a avaliação feita pelo professor com a auto-avaliação, como mais um ponto que reflete uma visão da concepção de avaliação que os autores do texto têm. A avaliação não pode ser vista como "mera formalidade", como instrumento de poder do professor ou, como processo unilateral em processos educacionais que visam a autonomia e a real construção do saber.

Quando lemos que "A avaliação responsável é fundamental para que o diploma conferido seja legitimado pela sociedade" entendemos que é a primeira vez que a relação avaliação e certificação estão colocadas em seus devidos lugares. Isto é, concordamos com a idéia de que a avaliação bem feita legitima um diploma. Mas a avaliação ou "o exame", termo que tem aparecido na legislação, não deve ser tratada como algo que existe, exclusivamente em função de um diploma ou certificado.

O termo "avaliação" aparece em outros momentos do documento "Indicadores de qualidade", mas não os abordaremos por estarem ligados a contextos que não fazem parte do escopo desse trabalho como, por exemplo, a avaliação institucional.

\section{Síntese}

Por meio da documentação analisada, podemos concluir que a legislação nacional que regulamentada a educação a distância a partir de 1996, oferece poucas diretrizes sobre a avaliação da aprendizagem.

As referências encontradas para a "avaliação" são bastante amplas. Referem-se à avaliação institucional, avaliação de programas para fins de credenciamento ou autorização, etc. Diretamente relacionada a aprendizagem, na grande maioria dos documentos analisados, o tema é tratado sob a forma de determinar como devem ser feitos os "exames", operacionalmente. Nesse sentido, notamos uma preocupação em definir que os exames para cursos à distância devam ser 
realizados presencialmente, sem argumentação, pelo menos explicitamente, que justifique tal exigência.

Mesmo quando pensamos ter encontrado algum dispositivo que considerasse mais claramente as questões relativas à avaliação da aprendizagem em cursos a distância, logo a seguir, vimos, o que julgamos como um contra senso. Estamos referindo-nos ao o Decreto $n$ 5622, que diz que a avaliação em EAD deve ser feita por meio de atividades programadas durante o curso e exames. Mas logo após é determinado que os resultados dos exames presenciais devem prevalecer sobre quaisquer outras formas de avaliação a distância. Tal colocação nos faz pensar que nossos legisladores ainda não $\mathrm{s}$ apropriaram corretamente do conceito e características da Educação a Distância. Parece-nos que a única forma que encontram para redigir diretrizes para essa modalidade de ensino foi associando-a em alguns momentos e, em outros contrapondo-a a educação presencial.

Quando legislamos ou trabalhamos com EAD precisamos ter claro que ela não é diferente apenas porque usa uma ou mais mídias para a transmissão de informações. Trata-se de uma modalidade e abordagem diferente, com objetivos, métodos, mídias, estratégias e alunos diversos do ensino presencial. Não é possível fazer EAD pensando no que ela é diferente do presencial.

Com suas especificidades, a EAD, requer que a avaliação da aprendizagem também seja considerada de maneira própria, mas sem ignorar todos os estudos, publicações e avanços propostos pelos especialistas da área.

Não encontramos tal preocupação ou cuidado na legislação vigente, com exceção do documento Referenciais de qualidade para cursos de graduação a distância. Mas mesmo sendo um documento oficial não tem a força legal de uma portaria ou decreto.

Não acreditamos que apenas leis possam assegurar e construir processos de educação de boa qualidade. Mas as normas oficiais devem traçar diretrizes e definir políticas educacionais que garantam a qualidade que se espera da educação. Sendo 
assim, não acreditamos que detalhamentos pedagógicos sobre a avaliação da aprendizagem, ou qualquer outro item, devam ser motivo de preocupação das pessoas que traçam as políticas educacionais de um país. Entendemos que nem cabe tal proposição na legislação. No entanto, não podemos nos abster de diretrizes que nos falem sobre qual é a educação que queremos para o país, e, para isso precisamos ter claramente definidas as concepções de homem, mundo, sociedade, educação, currículo, conteúdos, avaliação, etc. norteiam nossas decisões em termos de políticas e diretrizes educacionais.

Depois da análise da legislação pertinente a Educação a Distância, julgamos importante investigar como a questão da avaliação da aprendizagem é tratada na legislação referente a educação presencial.

\section{A LDB e a concepção de avaliação}

Com o intuito de investigar como a legislação educacional nacional trata as questões relativas a avaliação da aprendizagem, elegemos a Lei de Diretrizes e Bases (LDB) de 1996, num primeiro momento. Tal escolha se justifica, em relação a LDB por se tratar da lei máxima em termos educacionais e, como o próprio nome diz deve estabelecer as bases para a educação nacional.

O termo "avaliação" aparece mais de vinte vezes no texto da LDB e o termo "verificação" (da aprendizagem ou do rendimento) duas. Apesar de encontrarmos em um único artigo o conceito de "avaliação" diretamente relacionado com diretrizes para a avaliação da aprendizagem, podemos apreender, mesmo que indiretamente, a concepção de avaliação presente na lei.

A seguir, serão citados dois trechos das LDB que sustentam a concepção apreendida, e explicitada nas palavras de Ramal ${ }^{71}$

O processo de avaliação deve ter como objetivo detectar problemas, servir como diagnóstico da realidade em função da qualidade que se deseja atingir. Não é definitivo nem rotulador, não visa a estagnar, e sim a superar as deficiências.

\footnotetext{
${ }^{71}$ RAMAL, A.C. Lendo no viés das palavras: Concepções de avaliação na LDB. Revista da Educação CEAP, ano 6, n. 21, junho, p 33-47, 1998.
} 
O Art.9 . - A União incumbir-se-á de:

VI. Assegurar processo nacional de avaliação do rendimento escolar no ensino fundamental, médio e superior, em colaboração com os sistemas de ensino, objetivando a definição de prioridades e a melhoria da qualidade do ensino.

Art. 46 - A autorização e o reconhecimento de cursos, bem como o credenciamento de instituições de educação superior, terão prazos limitados, sendo renovados, periodicamente, após o processo regular de avaliação.

$\S 10$. - Após um prazo para saneamento de deficiências eventualmente identificadas pela avaliação a que se refere este artigo, haverá reavaliação (...).

Os artigos supracitados pressupõem uma concepção de avaliação que não está preocupada com sanções ou classificações, mas como um processo que possa fornecer dados e informações para a proposição de novas ações para a melhoria da qualidade do processo educacional como um todo. Mas será que é possível estender essa concepção de avaliação quando a lei trata especificamente da aprendizagem?

Para respondermos a pergunta acima, voltamos a LDB e após análise podemos dizer que em alguns momentos ela é extremamente clara e em outros ela peca pela ausência de um posicionamento explicito

Nos artigos 24 e 36 , encontramos o mesmo espírito que norteia as avaliações institucionais está presente na avaliação da aprendizagem, isto é, não deve ser pontual, não deve ter caráter definitivo, deve servir como diagnóstico e norteador de novas ações e não deve ter caráter punitivo, como podemos ver abaixo, na transcrição do referido artigo.

Art. 24. A educação básica, nos níveis fundamental e médio, será organizada de acordo com as seguintes regras comuns: critérios:

$V$ - a verificação do rendimento escolar observará os seguintes a)avaliação contínua e cumulativa do desempenho do aluno, com prevalência dos aspectos qualitativos sobre os quantitativos e dos resultados ao longo do período sobre os de eventuais provas finais.

(...) 
Art. 36, O currículo do ensino médio observará o disposto na Seção I deste Capítulo e as seguintes diretrizes:

II - adotará metodologias de ensino e de avaliação que estimulem a iniciativa dos estudantes;

$\S 1^{\circ}$ Os conteúdos, as metodologias e as formas de avaliação serão organizados de tal forma que ao final do ensino médio o educando demonstre:

I - domínio dos princípios científicos e tecnológicos que presidem a produção moderna;

II - conhecimento das formas contemporâneas de linguagem

No entanto, quando a LDB fala da Educação de Jovens e Adultos (LDB), a questão da avaliação restringe-se a determinação de exames para o prosseguimento de estudos, ou seja, com finalidades certificatórias, como mostra o texto a seguir:

Art. 38. Os sistemas de ensino manterão cursos e exames supletivos, que compreenderão a base nacional comum do currículo, habilitando ao prosseguimento de estudos em caráter regular.

$\S 1^{\circ}$ Os exames a que se refere este artigo realizar-se-ão:

I - no nível de conclusão do ensino fundamental, para os maiores de quinze anos;

II - no nível de conclusão do ensino médio, para os maiores de dezoito anos.

$\S 2^{\circ}$ Os conhecimentos e habilidades adquiridos pelos educandos por meios informais serão aferidos e reconhecidos mediante exames.

Ao analisar a LDB, buscando referências explícitas em relação a diretrizes para avaliação da aprendizagem, propriamente dita, encontramos razões para afirmar que esse mesmo espírito que norteia as avaliações institucionais está presente na avaliação da aprendizagem, isto é, não deve ser pontual, não deve ter caráter definitivo, deve servir como diagnóstico e norteador de novas ações e não deve ter caráter punitivo.

Para o Ensino Superior, no que tange a avaliação, a LDB define, no Art. 47:

$\S 2^{\circ}$ Os alunos que tenham extraordinário aproveitamento nos estudos, demonstrado por meio de provas e outros instrumentos de avaliação específicos, aplicados por banca examinadora especial, poderão ter abreviada a duração dos seus cursos, de acordo com as normas dos sistemas de ensino.

O que não revela os princípios norteadores ou que subsidiem a avaliação da aprendizagem, como o faz para o ensino fundamental e médio. Tal posicionamento ou a falta de um remeteu-nos às diretrizes curriculares nacionais das licenciaturas 
na tentativa de encontrar indícios que possam nortear como é considerada a avaliação da aprendizagem nesse nível de ensino.

Recorremos às Diretrizes Curriculares Nacionais das licenciaturas e não a outros cursos de nível superior porque são elas, as licenciaturas, que formam, prioritariamente, professores que atuarão no ensino fundamental e médio. Sendo assim, esperávamos encontrar orientações para as licenciaturas coerentes com o que se espera e se define para a avaliação da aprendizagem nos níveis de ensino que esses profissionais atuarão.

Ao realizar a análise das diretrizes para os cursos de História, Letras, Geografia estabelecidas no Parecer CNE/CES 492/2001, publicado no Diário Oficial da União em 09/07/2001, nada encontramos em relação a avaliação da aprendizagem.

As diretrizes para o curso de História valorizam a formação do bacharel como historiador com uma longa introdução que enfatiza substituição do antigo currículo mínimo por essas diretrizes em função de novos contextos sociais e acadêmico, da ampliação das áreas de atuação desse profissional, do uso e produção de novas fontes documentais como vídeos e multimídia, entre outros fatores. Em relação a formação para o Magistério, o posicionamento remete-nos a um certo descaso, como se fosse algo secundário, pois fica condicionado a "possibilidade, necessidades e interesses das Instituições de Ensino Superior". Com isso, entendemos que a prioridade é formar o Historiador e, se possível, o professor de História, como pode ser lido no próprio texto do CNE no item que fala do Perfil do Egresso, transcrito a seguir:

\footnotetext{
Atendidas estas exigências básicas e conforme as possibilidades, necessidades e interesses das IES, com formação complementar e interdisciplinar, o profissional estará em condições de suprir demandas sociais específicas relativas ao seu campo de conhecimento (magistério em todos os graus, preservação do patrimônio, assessorias a entidades públicas e privadas nos setores culturais, artísticos, turísticos etc.
}

O referido texto apresenta separadamente as competências e habilidades gerais e as específicas para a licenciatura. Em relação a esta última, as competências e habilidades referem-se aos conteúdos trabalhados no ensino fundamental e médio e 
"ao domínio dos métodos e técnicas pedagógicas que permitem a transmissão do conhecimento para os diferentes níveis de ensino".

Como dissemos anteriormente, no capítulo referente a avaliação da aprendizagem, entendemos que o uso do termo "transmissão do conhecimento" pressupõe que ele já está pronto e acabado e que ao aprendiz resta o papel de simplesmente se adaptar e memorizar tais conhecimentos. Posição esta denominada pelo professor Paulo Freire de "educação bancária", que não mantém nenhuma relação de proximidade com o que é estabelecido pela própria LDB em relação a avaliação que deve ser feita no ensino fundamental e médio.

Nas diretrizes para o curso de Geografia, diferentemente do curso de História não há nenhuma referência à formação para o magistério no item Perfil do Egresso. Ela se faz presente no item Organização do Curso, quando diz que os colegiados das instituições podem organizar o curso em quatro níveis de formação: de bacharéis, aplicada-profissional, de docentes e de pesquisadores. Além disso, se abstém de qualquer orientação ao dizer que: "O curso de licenciatura deverá ser orientado também pelas Diretrizes para a Formação Inicial de Professores da Educação Básica em cursos de nível superior".

As diretrizes para o curso de Letras adotam o mesmo procedimento que as de Geografia quando dizem que os cursos de licenciatura deverão ser orientados "também pelas Diretrizes para a Formação Inicial de Professores da Educação Básica em cursos de nível superior."

Especificamente em relação às diretrizes para os cursos de Geografia e Letras, ressaltamos que elas delegam a responsabilidade de estabelecer orientações nacionais para a formação de professores para outra legislação como se as competências e habilidades para dar aula de geografia fossem absolutamente desvinculadas do saber do geógrafo, por exemplo.

Tal posicionamento condiz com os parâmetros anteriores a LDB de 1996 quando a Licenciatura era, normalmente, tratada como um apêndice do Bacharelado, o que 
caracterizou o " $3+1$ ". Isto é, os cursos tinham três ou mais anos para a formação do Bacharel e mais um ano para os alunos que queriam fazer a Licenciatura. Após a LDB/96 a Secretaria do Ensino Superior (SESu) consolidou, adequadamente, a direção da formação para três categorias de carreiras: Bacharelado Acadêmico; Bacharelado Profissionalizante e Licenciatura. Sendo assim, a Licenciatura ganhou identidade própria, terminalidade e um projeto específico.

No entanto as Diretrizes Nacionais para os cursos de graduação supra citados não apresentam orientações para que as instituições de ensino superior possam ter parâmetros para a elaboração de "projetos específicos" para as diferentes licenciaturas.

Nesse momento, perguntamo-nos como podemos desejar que o professor do ensino fundamental e médio trabalhe sob a perspectiva de uma avaliação continua e formativa se não temos nenhum amparo legal que garanta a ele a possibilidade de ter sido sujeito de um processo similar em seu curso de formação docente?

A resposta a tal pergunta nos foi dada pela própria legislação, no Parecer CNE/CP 9/2001, publicado no Diário Oficial da União em 18/01/200, que define Diretrizes Curriculares Nacionais para a Formação de Professores da Educação Básica, em nível superior, curso de licenciatura, de graduação plena, quando nos apresenta o conceito de simetria invertida. Isto é, o professor "aprende a profissão no lugar similar àquele em que vai atuar, porém, numa situação invertida". A mesma legislação afirma que essa condição de simetria invertida exige que haja coerência entre o que se faz na formação e o que dele se espera como profissional.

Explicitando esse conceito, o relator do Parecer no diz que:

A compreensão desse fato evidencia a necessidade de que o futuro professor experiencie, como aluno, durante todo o processo de formação, as atitudes, modelos didáticos, capacidades e modos de organização que se pretende venham a ser concretizados nas suas práticas pedagógicas. Nesta perspectiva, destaca-se a importância do projeto pedagógico do curso de formação na criação do ambiente indispensável para que o futuro professor aprenda as práticas de construção coletiva da proposta pedagógica da escola onde virá a atuar.

A consideração da simetria invertida entre situação de formação e de exercício não implica em tornar as situações de aprendizagem dos cursos 
de formação docente mecanicamente análogas às situações de aprendizagem típicas da criança e do jovem na educação média. Não se trata de infantilizar a educação do professor, mas de torná-la uma experiência análoga à experiência de aprendizagem que ele deve facilitar a seus futuros alunos.

Percebemos nesse Parecer uma definição clara do que se espera do professor, como isso pode e deve ser feito e, principalmente, qual a concepção de educação e portanto de avaliação. Encontramos nele a visão de uma educação preocupada com a aprendizagem, uma educação que reconhece que o conhecimento é construído pelo sujeito em interação com a realidade e, portanto não pode ser simplesmente "transmitido" e, como o próprio relator define:

O processo de construção de conhecimento desenvolve-se no convívio humano, na interação entre o indivíduo e a cultura na qual vive, na e com a qual se forma e para a qual se forma. Por isso, fala-se em constituição de competências, na medida em que o indivíduo se apropria de elementos com significação na cultura.

Temos ainda a Resolução CNE/CP 1, de fevereiro de $2002^{72}$, que reitera a concepção de educação e de avaliação da aprendizagem do Parecer CNE/CP 9/2001, quando no Art. $3^{\circ}$ diz que

A formação de professores que atuarão nas diferentes etapas e modalidades da educação básica observará princípios nortadores desse preparo para o exercício profissional específico, que considerem:

II - a coerência entre a formação oferecida e a prática esperada do futuro professor, tendo em vista:

a) a simetria invertida, onde o preparo do professor, por ocorrer em lugar similar àquele em que vai atuar, demanda consistência entre o que faz na formação e o que dele se espera;

b) a aprendizagem como processo de construção de conhecimentos, habilidades e valores em interação com a realidade e com os demais indivíduos, no qual são colocadas em uso capacidades pessoais;

d) a avaliação como parte integrante do processo de formação, que possibilita o diagnóstico de lacunas e a aferição dos resultados alcançados, consideradas as competências a serem constituídas e a identificação das mudanças de percurso eventualmente necessárias.

Chamamos a atenção para o item "d" que ao dizer sobre o papel e da avaliação nos remete ao conceito de avaliação formativa de Charles Hadji e apresentado no capítulo sobre avaliação da aprendizagem.

\footnotetext{
${ }^{72}$ A Resolução CNE/CP $1 / 2002$ foi republicada em abril de 2002 por ter saído com incorreção em março de 2002.
} 


\section{Síntese}

A partir das análises realizadas percebemos, de uma forma geral, discrepâncias na legislação que pretende estabelecer as Diretrizes Nacionais para a educação. Temos documentos que tratam o conhecimento como algo que pode ser "transmitido" e outros que concebem o conhecimento como algo a ser construído pelo sujeito, por exemplo. $E$, isso, não é apenas um simples exemplo, infelizmente, pois é a partir da concepção que temos sobre o conhecimento é que construímos nossas visões de educação, de aprendizagem, de ensino e de avaliação da aprendizagem, que serão consolidados na nossa prática pedagógica.

Além disso, tais discrepâncias levam-nos a pensar que na verdade nós não temos uma proposta de educação enquanto nação. As diretrizes educacionais, que pretendem ser nacionais, refletem apenas as concepções de grupos de legisladores e não o projeto educacional do país.

No entanto, O Art. 16 da Resolução CNE/CP 1, de fevereiro de 2002 traz algum tipo de conforto quando diz que:

\footnotetext{
O Ministério da Educação, em conformidade com $\S 1^{\circ}$ Art. $8^{\circ}$ da Lei 9.394 , coordenará e articulará em regime de colaboração com o Conselho Nacional de Educação, o Conselho Nacional de Secretários Estaduais de Educação, o Fórum Nacional de Conselhos Estaduais de Educação, a União Nacional dos Dirigentes Municipais de Educação e representantes de Conselhos Municipais de Educação e das associações profissionais e científicas, a formulação de proposta de diretrizes para a organização de um sistema federativo de certificação de competência dos professores de educação básica.
}

O conforto vem da esperança de que a intenção de organizar um sistema federativo de certificação de competência dos professores de educação básica possa ser o prenúncio da criação de uma real política de educação nacional. Mas, além da referida certificação é preciso trabalhar na formação e não apenas em mais um tipo de exame para simplesmente mostrar o que os avaliados não sabem. Caso essa atenção à formação inicial não seja dada, estaremos mais uma vez praticando uma avaliação punitiva e classificatória, muito distinta de uma avaliação que objetiva refazer percursos e a serviço da aprendizagem. 
A seguir apresentaremos o quadro sinótico da legislação analisada.

\begin{tabular}{|c|c|}
\hline $\begin{array}{l}\text { Lei } n^{\circ} .9 .394 \text {, de } 20 \text { de dezembro de } 1996 \text { (artigo } \\
\text { 80). }\end{array}$ & Estabelece as Diretrizes e Bases da Educação Nacional \\
\hline Decreto $n^{\circ} .2494$ de 10 de fevereiro de 1998. & Regulamenta o Art. 80 da Lei nº. 9394/96 \\
\hline Decreto $n^{\circ} .5622$, de 19 de dezembro de 2005 & Regulamenta o Art. 80 da Lei nº. 9394/96 \\
\hline Portaria MEC n. 301 de sete de abril de 1998 & $\begin{array}{l}\text { Normatiza os procedimentos de credenciamento de } \\
\text { instituições para a ofeta de cursos de graduação e educação } \\
\text { profissional tecnológica a distância. Dispõe sobre a forma de } \\
\text { apresentação do projeto em EAD }\end{array}$ \\
\hline $\begin{array}{l}\text { Portaria MEC n. } 2253 \text { de } 18 \text { de dezembro de } \\
2001\end{array}$ & $\begin{array}{l}\text { Normatiza a oferta de disciplinas, em seu todo ou em parte, } \\
\text { em cursos presenciais, em modalidade a distância }\end{array}$ \\
\hline Portaria MEC n. 4.059, de 10 de dezembro 2004 & $\begin{array}{l}\text { Revoga a portaria } \mathrm{n}^{\circ} .2253 / 01 \text { - mantendo a oferta de } \\
\text { disciplinas, em seu todo ou em parte, em cursos presenciais, } \\
\text { em modalidade a distância }\end{array}$ \\
\hline Resolução CNE/CP 1/2002 & $\begin{array}{l}\text { Institui Diretrizes Curriculares Nacionais para a Formação de } \\
\text { Professores da Educação Básica, em nível superior, curso } \\
\text { de licenciatura, de graduação plena }\end{array}$ \\
\hline Parecer CNE/CES 492/2001 & $\begin{array}{l}\text { Institui as Diretrizes Curriculares Nacionais dos cursos de } \\
\text { Filosofia, História, Geografia, Serviço Social, Comunicação } \\
\text { Social, Ciências Sociais, Letras, Biblioteconomia, } \\
\text { Arquivologia e Museologia }\end{array}$ \\
\hline Parecer CNE/CP 9/2001 & $\begin{array}{l}\text { Institui Diretrizes Curriculares Nacionais para a Formação de } \\
\text { Professores da Educação Básica, em nível superior, curso } \\
\text { de licenciatura, de graduação plena }\end{array}$ \\
\hline $\begin{array}{l}\text { Referenciais de qualidade para cursos de } \\
\text { graduação à distância }\end{array}$ & $\begin{array}{l}\text { Estabelece os referenciais de qualidade para cursos de } \\
\text { graduação à distância }\end{array}$ \\
\hline
\end{tabular}

Quadro 5 - Quadro sinótico da legislação analisada

O primeiro material que analisamos é o da Universidade Metodista, denominado "Orientação Didático-Pedagógica em cursos a distância", obtido no site http://EaD.metodista.br/ebook/e-book.pdf , em janeiro de2009.

O referido documento deixa explícito que ele foi elaborado com o objetivo de detalhar e refletir sobre o papel do professor tutor na Educação a Distância, não se 
tratando, assim, do Projeto Pedagógico em si. Mas julgamos relevante analisá-lo por acreditarmos que em um documento dessa natureza encontraríamos informações relativas a avaliação da aprendizagem

Nas primeiras páginas do documento encontramos:

\begin{abstract}
A aprendizagem por parte de adultos ou jovens adultos depende de avaliações que levem a construir o conhecimento a partir dos pontos fortes e fracos, sendo que ambos os aspectos merecem ser destacados de maneira positiva. $\mathrm{O}$ aluno que percebe um olhar acurado sobre a qualidade do seu trabalho por parte dos tutores tem a possibilidade de saber exatamente em que precisa se aperfeiçoar. Além disso, as sugestões sobre como melhorar o desempenho acadêmico devem ser específicas e tratar dos assuntos com profundidade, apontando caminhos onde buscar mais informações confiáveis e úteis para avançar. ${ }^{73}$
\end{abstract}

Tal afirmação leva-nos a entender que o autor percebe a avaliação como algo contínuo e que tem como função auxiliar a aprendizagem. Não demonstra uma preocupação com exames e certificações como encontramos nos documentos legais. Para Sathler, considerando o trecho apresentado, a avaliação não é um fim em si mesmo mas, serve como direcionamento de futuras ações tanto para professores como para alunos, uma vez que procurar ver quais foram os avanços, limites e dificuldades que o aluno está tendo para que ele se sinta confiante a continuar aprendendo.

O autor afirmar que a aprendizagem de adultos depende ${ }^{74}$ desse tipo de avaliação. Conceito esse que julgamos necessitar de confirmação se abrange apenas a população adulta.

Além das análises feitas acima, um último ponto merece destaque no trecho citado, que é a indicação de como o professor pode auxiliar ou facilitar a aprendizagem. Isto é, as sugestões dadas pelos professores para os alunos devem ser pontuais, específicas, devem apresentar caminhos reais e concretas. Não devendo permanecer na simples constatação genérica, como por exemplo, "você precisa

\footnotetext{
${ }^{73}$ SATHLER, Luciano. A tutoria em cursos superiores a distância. In SATHLER, L.: AZEVEDO, A.B. Orientação pedagógica em cursos a distância. São Bernardo do Campo/São Paulo: UMESP, 2008.

${ }^{74}$ Grifo nosso
} 
melhorar seu texto", sem explicitar quais aspectos do texto precisam ser aprimorados e onde e como o aluno pode "melhorar o texto."

$\mathrm{Na}$ página 14 do mesmo texto, o autor apresenta uma série de indicadores de desempenho que podem orientar o professor-tutor a realizar um bom trabalho de tutoria, segundo Muirhead ${ }^{75}$. Mas citaremos apenas uma, a que diz respeito ao nosso tema de pesquisa, ou seja:

O tutor deve "emitir comentários específicos, detalhados e construtivos a respeito das atividades entregues por alunos, que oriente quanto a possíveis melhoras tanto no presente quanto em futuros trabalhos."

Esse indicador como atributo de boa qualidade do trabalho de tutoria mostra-se diretamente ligado à concepção do papel da avaliação na aprendizagem já explicitado no primeiro trecho citado. No entanto, ele traz à tona um aspecto bastante interessante da avaliação: "ela deve servir para melhoras no presente e em trabalhos futuros". Tal colocação chama-nos a atenção por ressaltar que a avaliação não deve ser feita e nem servir para um dado momento e que ela pode ajudar o aprendiz a aprender significativamente ${ }^{76}$, que o que ele aprendeu hoje pode servir como alavancador de novas aprendizagens no futuro ${ }^{77}$.

Na seqüência do documento, o autor apresenta a um trecho de ARETIO,2002 ${ }^{78}$ que fala da necessidade do professor-tutor aprender técnicas de avaliação (autoavaliação e avaliação heterogênea). O quê, como, quando avaliar? Estilos de correção e qualificação e modos de realizar comentários nos trabalhos e provas.

Tal preocupação merece destaque, entre outros motivos, porque reconhece que a educação a distância tem características próprias, é algo novo e que as práticas

\footnotetext{
${ }^{75}$ Inserir Bibliografia Completa de MUIRHEAD 2005,p.108

${ }^{76}$ Segundo Ausubel a aprendizagem significativa é um processo por meio do qual uma nova informação é acoplada a uma estrutura cognitiva particular, específica e prévia. Sendo assim, "o fator mais importante que influi na aprendizagem é aquilo que o aluno já sabe. Isto deve ser averiguado e o ensino deve depender desses dados" (Ausubel, Novak e Hanesian, 1983).

${ }_{78}$ Conceito do Piaget assimilação e acomodação.

${ }^{78}$ ARETIO, Lorenzo, G. La educación a distância - de la teoria a La pratica. Barcelona/Espanha: Ariel Educação, 2002.
} 
utilizadas na educação presencial não podem simplesmente serem repassadas para o ensino a distância. Sendo assim, há a necessidade de aprender a trabalhar nessa modalidade de ensino, inclusive no que diz respeito à avaliação da aprendizagem.

No segundo artigo desse documento, "O professor-tutor e as ferramentas e metodologias de interação no ambiente virtual de aprendizagem e na Web", COSTA $(2008)^{79}$ refere-se a avaliação da seguinte forma:

No caso de tarefas e avaliações, além do conteúdo solicitado as tarefa ou avaliação, é possível dar o parecer (no caso de tarefa) ou a nota (no caso da avaliação). O conteúdo (descrição e parâmetros da tarefa ou avaliação é idêntico para todos os pólos).

Entendemos que se trata de orientação para o professor-tutor usar o sistema de informática (LMS) ,no entanto, ao diferenciar o tratamento que pode ser dado entre "as tarefas' e "a avaliação" pode ser indicativo de compreensões e valores diferentes par não é a cada uma das ações. A partir do documento não é possivel afirmar se esse tratamento diferenciado é decorrente do LMS ou se é uma decisão didático-pedagógica.

No item, do mesmo texto, Plano de Avaliações, o autor diz que

'tão importante quanto o Plano de Ensino é o Plano de Avaliações'

Nesse momento, pensamos que encontraríamos outros indicadores da concepção da avaliação da aprendizagem usada nesse projeto, no entanto, a frase seguinte define o que está sendo denominado Plano de Avaliações é simplesmente o anúncio de como, operacionalmente, as notas serão calculadas. Nesse mesmo tópico, outras vezes a "avaliação" é citada, mas sempre no sentido de como se calcular "as notas" (peso ou valor absoluto).

O segundo documento analisado foi o Projeto Pedagógico do Curso de Graduação em Administração na Modalidade a Distância da Universidade Federal de Santa

${ }^{79}$ COSTA, L. V. O professor-tutor e as ferramentas e metodologias de interação no ambiente virtual de aprendizagem e na Web. In SATHLER, L.: AZEVEDO, A.B. Orientação pedagógica em cursos a distância. São Bernardo do Campo, SP:UMESP, 2008. 
Catarina que, capítulo no "Diretrizes para a Formação do Curso de Administração" diz que a proposta metodológica deve considerar, entre outros fatores:

Nortear as atividades avaliativas da aprendizagem, segundo uma concepção que resgate e revalorize a avaliação como informação e tomada de consciência de problemas e dificuldades, com o fim de resolvê-los, para estimular e orientar a auto-avaliação.

O exposto acima, relativo à concepção de avaliação da aprendizagem é reiterado e coerente com os três conceitos que o documento apresenta como sendo estruturantes da proposta pedagógica do curso. Dos três conceitos apresentados como fio condutor de todo o curso ressaltamos o conceito de CONSTRUÇÃO, apresentado como:

\begin{abstract}
É outro conceito que perpassa todas as áreas e núcleos de conhecimento do curso, para que o aluno reforce sua compreensão de que, se os conhecimentos são históricos e determinados, eles são resultados de um processo de construção que se estabelece no conjunto de relações homem/homem, homem/natureza e homem/cultura.

Essas relações, por serem construídas num contexto histórico e, culturalmente, determinado, jamais serão lineares e homogêneas e que ele, aluno, deve se imbuir do firme propósito de transformar-se num profissional que não só aplica conhecimentos, mas também que produz conhecimentos;
\end{abstract}

Podemos perceber por meio das transcrições feitas que a concepção de educação explicitada sustenta a concepção de avaliação da aprendizagem. Relação essa apontada anteriormente nesse nosso trabalho. Uma educação que parte do princípio que o conhecimento é construído trabalha com a avaliação da aprendizagem como fonte de informação para resolver as dificuldades encontradas pelos aprendizes. Isto é, faz uma avaliação formativa e como diz Hadji "a avaliação só é formativa se for informativa"

O mesmo documento indica dois níveis de avaliação da aprendizagem. O primeiro refere-se a avaliações feitas a distância por meio dos registros das ações de cada aluno feitas pelo LMS, quando serão analisadas a participação e o envolvimento dos alunos e o segundo nível diz respeito a avaliações presencias "com proposições, questões e temáticas que Ihe exijam não só síntese dos conteúdos trabalhados, mas

${ }^{80}$ HADJI, Charles. Avaliação desmistificada. Porto Alegre: Artmed, 2001. 
também outras produções. Diz ainda que se o aluno não obtiver o desempenho desejado ele deve refazer seus estudos. No entanto, não há referência como será composto o perfil "de desempenho desejado" considerando os dois níveis de avaliação. Isto é, será que os resultados obtidos nas avaliações presenciais terão prevalência em relação as avaliações feitas a distância?

O terceiro documento analisado é o Projeto Pedagógico do Curso de PósGraduação - Especialização a Distância - Tecnologias da Informação e da Comunicação Aplicadas à Educação, da Universidade Federal de Santa Maria. Nele, relativo a avaliação da aprendizagem, encontramos que ela deverá ser permanente e em processo e, que o exame final será presencial. $O$ documento sugere que os professores realizem quatro níveis de avaliação: acompanhamento do professor; auto-avaliação; avaliação presencial (prova, trabalho, seminário, etc.); acompanhamento do Seminário Integrador ou equivalente. Além disso, fica explicitado que:

- Será considerado, obrigatoriamente, o controle do cumprimento dos compromissos acadêmicos propostos pelo curso"

- Consistirá em processo sistemático, continuado e cumulativo, dentro de cada componente curricular;

- Abrangerá as diferentes atividades, ações e iniciativas didático pedagógicas compreendidas em cada componente curricular, podendo envolver situações de auto-avaliação;

No entanto, da mesma forma que no Projeto da Universidade Federal de Santa Catarina, nada é dito quanto a composição dos desempenhos obtidos nas avaliações ao longo do processo e a avaliação presencial.

Analisamos os documentos acima com o intuito de identificar às concepções de avaliação de aprendizagem nos documentos orientadores de curso a distância e, nos três documentos analisados encontramos dados que nos permitem concluir que, pelo menos, em termos documentais, eles propõem que a avaliação seja formativa. No entanto, em nenhum deles fica claro como praticar uma avaliação formativa se a legislação define que os exames presenciais prevalecem sobre qualquer outro tipo 
de avaliação. Pensamos existir uma dicotomia entre o que se deseja, pelo menos em termos de discurso, e o que se pratica, em função da legislação vigente. Isto é, posso pensar na avaliação formativa durante o curso, no entanto o que define se o aluno será ou não aprovado é um exame final. 


\section{CONCLUSÕES}

Iniciamos esse trabalho buscando compreender quais são os pressupostos legais que definem a avaliação da aprendizagem em cursos a distância e como ela vem sendo considerada nos Projetos Pedagógicos para os cursos de nível superior. Para tanto, analisamos as Diretrizes Nacionais para cursos presenciais quanto à avaliação da aprendizagem e a legislação e documentos orientadores para cursos a distância no esforço de identificar aproximações e/ou contradições.

A segunda etapa do trabalho buscou em dois Projetos Pedagógicos e em um Manual de Orientação para cursos a distância, de livre acesso, de Instituições que oferecem cursos a distância de nível superior identificar como a avaliação da aprendizagem é considerada. Optamos por documentos de livre acesso por acreditarmos que dessa forma não sofreríamos nenhum tipo de mascaramento ingênuo ou intencional dos pressupostos definidos pelas instituições. Pois, durante nossa trajetória profissional, algumas vezes pudemos perceber que quando uma pessoa ou instituição se sente avaliada tende a responder o que o entrevistador está querendo ouvir. Além disso, nosso objetivo não foi de "apontar erros", mas o de realizar uma investigação com intenção de reconhecer o "estado da arte".

A seguir, apresentaremos nossas conclusões separadas em tópicos.

\section{Viabilidade de cursos a distância}

Percebemos em toda a literatura e por meio da nossa experiência profissional que, hoje, temos duas posições distintas em relação à educação a distância. Uma delas revela uma apologia à educação a distância e a outra corrente mostra-nos um certo desprezo, como se estivéssemos falando de algo de segunda linha.

Temos argumentos, que apresentaremos posteriormente, a favor da educação a distância, mas nesse momento queremos apontar os perigos das posições extremadas. 
Podem ser muitas as razões que sustentam a posição dos que demonstram descrédito em relação a cursos a distância. Não nos cabe nesse momento analisar todas, o que pode se tornar, inclusive, tema de uma nova pesquisa, mas temos, sim, que apontar algumas delas.

No Brasil, de maneira geral, quando falamos em educação a distância vem-nos à lembrança os primeiros e, mais divulgados, cursos do Instituto Universal Brasileiro que, no início dos seus trabalhos, ofereciam cursos a distância, utilizando mídia impressa, com o objetivo de propiciar uma formação profissional a seus alunos. Não estamos emitindo nenhum juízo de valor em relação a tais cursos, mas a população, de uma forma geral, criou a imagem de um curso de segunda linha. No entanto, associar à modalidade a distância de educação a uma única realização é um posicionamento, no mínimo, simplista, pois como mostramos no capítulo que discorre sobre história da educação a distância foram inúmeras, ao longo do tempo, as realizações nessa área. Além disso, tais pessoas parecem estar descoladas do seu tempo, pois remetem-se ao passado desconsiderando todos os avanços das tecnologias de informação e comunicação que permitem novas formas para a transmissão da informação e a interação ${ }^{81}$ entre aluno e professor. Mas esses avanços não seriam suficientes se não tivéssemos outros tantos avanços nas pesquisas sobre educação.

Mas o desrespeito à educação a distância não é privilégio da "população" de uma forma geral. Ele também se faz presente no mundo acadêmico e na esfera governamental. Em 2004 o Conselho Municipal de Educação da Prefeitura do Município de São Paulo publicou uma Deliberação ${ }^{82}$ que só portadores de diplomas de cursos presenciais poderiam participar de seus concursos públicos para provimento de cargos de professores de educação infantil e para as séries iniciais

\footnotetext{
81 "Uma das definições atribuídas pelo Dicionário eletrônico Houaiss ao termo interação é: "comunicação entre pessoas que convivem; diálogo, trato, contato". Característica essa, fundamental nas relações de ensino e aprendizagem. No entanto, não temos nenhuma garantia que ela aconteça nas modalidades presenciais ou a distância de educação, pois a comunicação não depende nem da presença física, nem de mídias, mas sim da intenção dos atores de tais processos. Evidentemente em cursos a distância, a disponibilidade de recursos tecnológicos que permitem canais de comunicação pode facilitar a interação, mas eles por si só nada garantem.

${ }^{82}$ Deliberação CME $n^{\circ} \quad 02 / 04$
} 
do ensino fundamental, apesar da declaração de voto do Conselheiro Bahij Amin Aur, que transcrevemos a seguir.

\footnotetext{
Voto com restrição à discriminação contra concluintes de cursos e programas não presenciais.

Juridicamente, não há sustentação para esta restrição, pois a modalidade de formação a distância é regular, prevista na LDB. Se sua oferta é por instituição devidamente credenciada e o curso é regularmente autorizado pelo órgão competente, seus efeitos são os mesmos de um curso presencial, conferindo os mesmos direitos de acesso a concurso ou processo seletivo. As provas correspondentes é que aferirão o essencial, que é a competência do candidato.

Não pode haver restrição ao acesso a concurso/processo seletivo, nem redução de direito ao exercício profissional.
}

Esse é apenas um exemplo dos tantos que nos deparamos na nossa história recente. Alguns concursos para preenchimento de vagas na docência, em universidades públicas, também têm vedado, explicitamente, a participação de portadores de diplomas obtidos por meio da educação a distância. Tais procedimentos desrespeitam de forma clara a Lei de Diretrizes de Bases de 1996, mais precisamente nos artigos 80 e 81.

As incertezas em relação a educação a distância já alcançou o sistema judiciário que ao menos tempo que deu ganho de causa à Prefeitura do Município de São Paulo negando a possibilidade de profissionais formados nessa modalidade de ensino prestarem um concurso público, reconheceu como legítimo o registro de diplomas obtidos em cursos de Biologia a distância, argumentando que o não reconhecimento de cursos a distância é inconstitucional.

Por outro lado, temos grupos que consideram a educação a distância uma verdadeira panacéia. Como se essa modalidade pudesse resolver e exterminar todos os problemas educacionais. Setores privados da educação, de forma desavisada, acreditam que reduzirão significadamente os seus custos se transformarem seus cursos presenciais em cursos a distância. Quem trabalha na área sabe que isso está muito longe de ser verdade. Estruturar e oferecer cursos a distância com a qualidade que qualquer curso deve ter, presencial ou não, requer um aporte financeiro alto e mesmo que os investimentos em equipamentos e 
recursos de infra-estrutura sejam diluídos e recuperados ao longo do tempo e com o aumento do número de alunos, os custos de uma forma geral não são expressivamente menores que os bons cursos presenciais. Há estudos que mostram e pormenorizam essa análise financeira, mas por não ser objeto do nosso estudo não são serão aprofundados.

Outro equívoco em relação às possibilidades da educação a distância, mas sobre o mesmo princípio da panacéia é que essa modalidade poderá superar as desigualdades de acesso a educação escolar. Não é a simples oferta de cursos em uma ou outra modalidade de educação que eliminará os sérios problemas de exclusão das classes economicamente menos favorecidas das escolas. Esse é um problema sério de estrutura sócio-econômica que só poderá ser seriamente enfrentado com políticas públicas adequadas e o envolvimento de toda a sociedade. Como bem mostra o Parecer CNE/CEB 41/2002 ${ }^{83}$, a educação a distância pode ser uma $^{84}$ das formas para o resgate de uma dívida social, quando diz:

\begin{abstract}
Para com os jovens e adultos, que não tiveram a oportunidade de ingressar ou de completar a educação básica, a Educação a Distância apresenta-se como uma das formas do país resgatar "uma dívida social não reparada para com os que não tiveram acesso a e nem domínio da escrita e leitura como bens sociais, na escola ou fora dela, e tenham sido a força de trabalho empregada na constituição de riquezas e na elevação de obras públicas. Ser privado deste acesso é, de fato, a perda de um instrumento imprescindível para uma presença significativa na convivência social contemporânea." ( Parecer CNE/ CEB 11/2000)
\end{abstract}

Num movimento de crescimento da oferta de cursos a distância, podemos constatar cursos de todas as espécies e em todas as áreas do conhecimento. O que se constitui em mais um engano no que se refere a essa modalidade, pois há certas habilidades que não conseguimos conceber que possam ser desenvolvidas por meio de cursos a distância, pelo menos com os recursos tecnológicos que temos disponíveis, hoje. Para exemplificar o que estamos dizendo usaremos uma provocação bastante coloquial, para a qual pedimos licença à seriedade acadêmica. Será que podemos aprender a nadar em cursos a distância? Ensinar e aprender a nadar exige que o aluno esteja, por exemplo, em uma piscina. Não é possível de nenhuma outra forma. Não há, hoje, recursos tecnológicos que consigam substituir a

\footnotetext{
83 Publicado no Diário Oficial da União de 24/12/2002

${ }^{84}$ grifo nosso
} 
piscina. Com isso queremos chamar a atenção que é preciso tomar muito cuidado com a oferta de cursos a distância quanto aos conteúdos e objetivos de cada curso, pois nem todos são passíveis de serem trabalhados a distância.

Para finalizarmos esse tópico posicionamo-nos claramente a favor da educação a distância, no entanto sem ufanismo. Percebemos o potencial da educação a distância para atender, por exemplo, uma das exigências de nossos tempos que é a necessidade da constante atualização dos profissionais de mais diferentes áreas de atuação. Sendo assim, percebemos essa modalidade como uma forte aliada da educação continuada, que atende pessoas com uma formação inicial, teoricamente, mais autônomas na regulação de seus processos de aprendizagem. Com isso não estamos afirmando que ela não possa ser oferecida para a formação inicial. Não vemos nenhuma restrição a esse respeito, desde que os cursos sejam adequadamente estruturados e que haja apoio para que os alunos aprendam a estudar a distância.

A educação a distância pode contribuir para a superação dos transtornos da deslocação física nos grandes centros urbanos. Todos que residem em grandes cidades sabem da dificuldade e do tempo que é necessário para se mover de um ponto a outro, o que muitas vezes impossibilita a realização de um curso. O tempo usado para o deslocamento seria muito mais bem aproveitado se o indivíduo estivesse participando do local de seu trabalho ou da sua própria residência de cursos a distância. Além disso, essa modalidade de educação permite que os interessados possam participar de cursos em qualquer local do mundo, sem se ausentar por períodos longos das suas atividades profissionais.

Existem excelentes cursos presenciais e outros com sérios problemas quanto a qualidade e, o mesmo acontece com os cursos oferecidos a distância. Portanto, não é a modalidade de educação que garante a boa qualidade ou a falta dela em um curso. Precisamos ser criteriosos quanto a essa questão e mais uma vez usaremos do coloquialismo para ilustrar o que estamos querendo dizer. A sabedoria popular no diz que quando usamos uma bacia para banhar uma criança e a água fica suja, basta trocar a água. Não é necessário jogar a criança, a bacia e água fora. Nesse 
verdadeiro arroubo da educação a distância que estamos vivendo é preciso tomar muito cuidado para não assumirmos posições extremadas que nos levariam a ignorar excelentes oportunidades da melhoria e acesso a educação, tanto no que diz respeito a não validar cursos a distância quanto na sua oferta desenfreada e sem critérios de qualidade seriamente estabelecidos e supervisionados.

Outros pontos poderiam ser levantados a favor da educação a distância, mas por não ser o objetivo desse trabalho queremos, neste momento, retomar a questão principal desta investigação que é a avaliação da aprendizagem nessa modalidade de ensino.

\section{Avaliação da Aprendizagem}

O marco teórico que sustenta nosso trabalho em termos de avaliação da aprendizagem pressupõe uma avaliação que esteja a serviço da aprendizagem, ou seja, ela deve ser formativa. Isto é, ela não deve ser encarada como um instrumento de poder e/ou classificação e não deve servir apenas para fins certificatórios.

A avaliação formativa objetiva trazer informações para alunos e professores. Para os alunos como meio de auto-regulação de seu processo de desenvolvimento e aprendizagem. Já para os professores, as informações obtidas devem servir para que ele conheça as dificuldades e possibilidades dos alunos e, a partir daí, pense novas estratégias de ensino com o intuito de criar situações que facilitem, de fato, a aprendizagem.

Nesse sentido, reiteramos que qualquer dispositivo utilizado para se realizar uma avaliação pode ser formativo, pois ele é apenas um meio para obter informação. $\mathrm{O}$ que fazemos com ela é que de fato caracteriza uma avaliação como formativa ou não.

Ao analisarmos a legislação específica para educação a distância não encontramos nenhum indício do que poderíamos chamar de uma "concepção de avaliação de aprendizagem". O que fica extremamente claro é a exigência de exames presenciais e a prevalência deles sobre qualquer outro tipo de avaliação. 
Nos documentos analisados nesse trabalho percebemos o propósito das instituições de trabalhar com a avaliação formativa, no entanto se o confrontarmos com a legislação vigente, surge-nos algumas questões, tais como:

Será que a prevalência da avaliação presencial, ignorando todas as outras avaliações realizadas no decorrer do curso não elimina a intenção de uma avaliação formativa?

Será que nossos legisladores, aqueles que definem as Diretrizes Nacionais da Educação, com tais medidas em relação a avaliação em cursos a distância, ainda não os vêem como uma educação de segunda linha?

Será que esses mesmos legisladores estão apenas preocupados com exames que possam garantir a certificação de diversos profissionais e assim melhorar as estatísticas nacionais, no cenário mundial, no que se refere à educação?

Será que o receio da existência de fraudes em cursos a distância, como por exemplo, não ser o aluno matriculado a fazer as tarefas e assim estar correndo o risco de certificar alguém sem capacidade para exercer uma profissão, não revelaria a falta de Diretrizes mais claras e ainda a ausência de instrumentos adequados para avaliar o trabalho das instituições de ensino?

Será que o exercício de fiscalização sobre o sujeito pode estar mascarando a falta de capacidade de acompanhar seriamente o trabalho das instituições?

Apesar de falarmos de legisladores, genericamente, percebemos e mostramos ao longo desse trabalho que alguns deles mostram sérias preocupações com os temas abordados e se posicionam de maneira coerente com uma educação que objetiva transformar a realidade. No entanto, como dissemos anteriormente, sentimos a falta de um Projeto de Educação para o país, o que permite que cada grupo de legisladores imprima suas crenças pessoais. 
As questões levantadas precisam ser pensadas e respondidas de forma profissional e não passional das posições radicais. Mas como Gatti e Barreto ${ }^{85}$ disseram a educação a distância é uma área nova que requer muitos estudos e temos, para os apaixonados pela educação, muita coisa a fazer.

\section{Quadro de Princípios}

Atendendo ao que nos propomos apresentaremos a seguir um quadro de princípios que podem subsidiar cursos a distância quanto a avaliação da aprendizagem. Tais princípios podem traduzir-se em inúmeras práticas avaliativas, sempre respeitando as características e especificidades dos diferentes cursos, objetivos, conteúdos, suportes e ferramentas, professores e alunos, enfim, de cada contexto educativo.

O quadro de princípios que construímos baseia-se em uma concepção de avaliação da aprendizagem, já descrita e explorada neste trabalho, que pressupõe:

- Todos os sujeitos ${ }^{86}$ são capazes de aprender;

- Os alunos devem ser considerados sujeitos ativos, construtores e participantes dos processos de ensino e aprendizagem;

- O homem se faz homem e se reconhece como tal na interação com outros homens e na transformação da realizadas;

- O conhecimento é construído pelo sujeito que o apreende por meio de problematizações; interações e reflexões;

- A avaliação da aprendizagem não deve ser um instrumento de classificação e exclusão;

- A avaliação da aprendizagem não deve ser um instrumento de poder e coerção.

Princípios

1. Acompanhamento de todas as ações dos alunos.

O professor deve acompanhar sistematicamente de todas as ações, atividades e das participações e ausências de cada um dos alunos. Esse acompanhamento é fundamental para que o professor consiga traçar um perfil do aluno no que diz

\footnotetext{
${ }^{85}$ GATTI, B. A. \& BARRETO, E. de Sá. Professores do Brasil: impasses e desafios, UNESCO Brasil, 2009

${ }^{86}$ o termo sujeito foi escolhido em detrimento de pessoa ou indivíduo por assumirmos o proposto por Paulo Freire no livro Educação para a Liberdade
} 
respeito a sua "freqüência" no ambiente e seu ritmo de trabalho. Caso o aluno esteja muito tempo "ausente", ou seja, não realizando as atividades, o professor deve entrar em contato com o intuito de identificar as razões que podem ser dificuldades com o ambiente ou problemas pessoais e, oferecer ajuda no que for preciso. Além disso, esse acompanhamento pode permitir que o professor identifique eventuais dificuldades de aprendizagem e a partir disso tomar as providências necessárias para que se consolide seu papel como facilitador da aprendizagem.

No entanto, é preciso tomar cuidado para não se criar estereótipos, como por exemplo, o aluno que ficou mais tempo terá um desempenho melhor. Essa relação é muito delicada de ser estabelecida pois desconsidera o tempo de aprendizagem de cada sujeito.

Esse acompanhamento pode ser formativo se for utilizado para orientar a aprendizagem sem preocupação com a classificação ou certificação. Além disso, esse acompanhamento pode servir para identificar métodos de trabalhos, atitudes dos alunos e processos de aprendizagem.

Para tanto, as ferramentas disponíveis atualmente nos LMS, na sua grande maioria, oferecem bons recursos. É possível precisar quais os momentos que o aluno entrou no sistema, qual a área visitou, por quanto tempo e se apenas visitou ou fez alguma tarefa, fornecendo relatórios completos.

2. Transparência do acompanhamento.

O professor deve informar ao aluno que esse acompanhamento é feito, mostrando total transparência da relação professor-aluno. É preciso deixar claro qual o objetivo desse acompanhamento, isto é, que ele tem um caráter de auxílio e não de investigação punitiva. Tal procedimento pode colaborar para que o aluno se sinta amparado e que não está sozinho, apesar da distância física. 
Além disso, é fundamental explicitar que esse acompanhamento é meramente quantitativo, uma vez que, atualmente, as ferramentas dos LMS disponíveis, só oferecem informações dessa natureza, nesse quesito.

O professor deve comunicar aos alunos se tais informações serão consideradas na composição da avaliação, reiterando o princípio da transparência.

\section{Natureza do feedbak.}

Além de informar que o acompanhamento é realizado, o professor deve divulgar os resultados desse acompanhamento aos alunos, permitindo que esse feedback também seja usado pelos sujeitos como instrumento de regulação da sua atuação.

A comunicação do que foi detectado pelo professor quando desse acompanhamento também deve ser feito com um caráter positivo. Os alunos que estão tendo boa freqüência e realizando as atividades também devem receber o feedback do professor, com mensagens de apoio e incentivo. Esse retorno não deve acontecer apenas quando o professor detectar dificuldades ou desempenhos insatisfatórios.

\section{Feedback contínuo}

O feedback deve ser dado em vários momentos do curso, isto é, ele deve ser contínuo. Ora com mensagens de estímulo dizendo do bom desempenho do aluno, como dissemos anteriormente, ora para apontar que o desempenho não está ocorrendo de modo satisfatório e oferecendo auxílio, quando necessário. 0 feedback, não pode ser dado apenas ao final do curso, pois ele perderia seu principal objetivo que é o de oferecer informações para professores e alunos sobre o processo que está ocorrendo. Além disso, ele jamais deve ser utilizado como mais um instrumento de poder para justificar uma reprovação, por exemplo, o que poderá acontecer se ele só for dado ao final do curso, pelo menos na interpretação de alguns alunos e professores. 
5. Domínio técnico dos recursos do LMS

O professor ou o profissional responsável pela elaboração dos dispositivos avaliativos deve conhecer muito bem todos os recursos que o LMS oferece para poder selecionar aquele ou aqueles mais adequados para cada situação. Essa apropriação do sistema pode evitar que o professor defina como dispositivo o mais fácil ou o que ele melhor conhecer e não o mais apropriado para a situação. O principal critério de escolha de um ou outro dispositivo de avaliação deve ser sua pertinência em relação ao que se quer avaliar ou, em outras palavras, aos objetivos da avaliação em determinado momento do curso.

O professor deve sempre saber responder porque escolheu um ou outro dispositivo de avaliação, tendo em vista o que diz BELLONI ${ }^{87}$, "a integração das inovações tecnológicas vai depender, então, da concepção de educação das novas gerações que fundamenta as ações políticas do setor."

6. Não submissão aos instrumentos.

O planejamento e a elaboração das atividades avaliativas devem ser condizentes com os recursos tecnológicos disponíveis, No entanto, nenhuma atividade educacional $e$, isso inclui a avaliação não podem se submeter aos recursos tecnológicos. Não podemos perde de vista que os recursos tecnológicos são "apenas ferramentas" a serviço da educação. Os objetivos da ação educacional devem estar sempre em primeiro plano. A medida que tenhamos clareza da ação educacional, do nosso público, dos conteúdos que serão trabalhados, aí sim podemos optar por essa ou aquela ferramenta, sem submetermo-nos a elas. Por exemplo, não podemos avaliar conteúdos procedimentais utilizando testes de múltipla escolha porque é a única ferramenta que o LMS dispõe. Se assim o fizermos estaremos avaliando algumas outras coisas menos se o aluno sabe ou não realizar o procedimento em questão.

${ }^{87}$ BELLONI, M. L. Educação a Distância. 2 ed. São Paulo: Autores Associados, 2001. 


\section{Vivência prévia}

No processo de apropriação das ferramentas de cada LMS, é importante que o professor já tenha vivenciado cada um deles como aluno. Isto é, já tenha estado na posição de aluno como sujeito avaliado. Considerando que as práticas educativas em educação a distância que utilizam os recursos da informática e da WEB são relativas novas, é imprescindível que os professores vivenciem as situações que seus alunos experimentaram para que eles possam se aproximar das condições que os alunos passarão. Isso pode ser facilmente feito nos processos de capacitação dos profissionais da educação que trabalharão com educação a distância.

8. Conhecer os dispositivos de avaliação.

O professor deve conhecer muito bem todos os dispositivos de a avaliação e aqui não se trata apenas de saber utilizar as ferramentas dos LMS. Mas de conhecer o conteúdo da avaliação em si. Esse princípio justifica-se porque em alguns casos, em cursos a distância, não é o professor ou tutor ${ }^{88}$ que elabora os instrumentos de avaliação. Eles podem ser elaborados por outros membros da equipe como os conteudistas ${ }^{89}$, por exemplo. Nesses casos, é imprescindível que os profissionais designados para a correção e o acompanhamento de cada aluno conheçam muito bem todos os dispositivos de avaliação no sentido de se ter claro os critérios de avaliação. Além disso, o professor deve interagir com os elaboradores contribuindo com informações sobre o desempenho dos alunos, suas necessidades, dificuldades e características pessoais, além de avaliar o próprio a própria avaliação.

\section{Colaboração na construção dos dispositivos de avaliação}

Ao ter elaborado um dispositivo de avaliação, o professor deve submetê-lo a apreciação de seus pares. Esse princípio não objetiva diminuir a autonomia do professor, mas sim garantir que o dispositivo de avaliação estará o mais claro possível. Ao elaborarmos uma questão, por exemplo, acreditamos, normalmente, que ela está clara e que não há dúvidas sobre o que está sendo solicitado. No

\footnotetext{
${ }^{88}$ Professor tutor ou simplesmente tutor é o profissional responsável por acompanhar um grupo de alunos, para motivá-los, tirar dúvidas e resolver eventuais problemas durante o curso.

${ }^{89}$ Os conteudistas são professores especialistas nas diferentes áreas do conhecimento responsáveis pelo elaboração e seleção do conteúdo que será trabalhado.
} 
entanto e apesar das nossas melhores intenções, isso nem sempre é verdade. Mostrá-la aos nossos pares possibilita que façamos o "teste da clareza". Eles poderão dizer se, de fato, estamos pedindo o que desejamos, se não há margem para outras interpretações além da que eu, como professor, desejo. Enfim, procurar evitar um dispositivo de avaliação que não esteja a serviço da aprendizagem.

10. Adequação as condições de correção

Os instrumentos de avaliação devem ser adequados, entre outros fatores, as possibilidades de correção. Isto é, não se deve, por exemplo, solicitar uma atividade que resultará em material que o professor não conseguirá ler e comentar toda a produção seja qual for a razão. Todas as atividades devem resultar um retorno para o aluno, não apenas dizendo o que está certo ou errado (correção automática), mas pontuando sua evolução e os pontos que merecem mais atenção. Este princípio envolve questões que vão além do campo de atuação do professor como, por exemplo, o número de alunos que estão sobre sua tutoria. O dimensionamento do número de alunos por tutor ou professor, normalmente, é feito pelos responsáveis administrativos do curso. Embora essa questão não seja de fácil solução tendo em vista a ausência da participação do professor em decisões administrativas, ele precisa considerar suas conseqüências nas atividades educacionais.

\section{O exercício da auto-avaliação.}

Atividades de auto-avaliação devem ser realizadas objetivando que o aluno aprenda a percebê-las como um instrumento que o ajudará a analisar seu próprio processo de aprendizagem e desempenho, sem nenhuma preocupação com notas ou conceitos. A auto-avaliação não deve ser um momento para que o aluno se atribua uma nota, mas deve criar condições para que ele reflita e relate o que aprendeu, quais foram suas maiores dificuldades, sua participação e etc. A auto-avaliação realizada por cada aluno pode ser comparada com a avaliação que o professor fez com o objetivo de estabelecer um diálogo esclarecedor para ambos e que se constitua em mais um instrumento orientador para os ajustes necessários para que a aprendizagem ocorra. 
12. Avaliação processual e avaliação final.

A legislação atual exige que em cursos a distância haja um exame presencial e que 0 resultado desse exame deve prevalecer em relação qualquer outra avaliação. Entendemos que a motivação para tal decisão pode resultar de uma das características dessa modalidade, que por mais redundante que possa parecer, é preciso dizer que o aluno não realiza a maior parte das atividades na presença física do professor. Tal especificidade pode gerar dúvidas, em alguns professores, se foi mesmo 0 aluno $X$ quem fez determinada tarefa. Provavelmente essa dúvida fez com que os legisladores definissem a exigência do exame presencial. No entanto, a supremacia do exame presencial em relação a outras atividades revela uma compreensão de avaliação como um instrumento de medida pontual e não considera o processo de aprendizagem de cada aluno.

Se por um lado podemos compreender a preocupação dos legisladores, por outro não podemos deixar de nos preocupar com essa "medida pontual", o exame, desconsiderando todo o processo de aprendizagem e as atividades realizadas durante o curso. Sendo assim, propomos, que sejam estudadas formas, em termos percentuais, por exemplo, de compor os resultados das avaliações ao longo do curso com o exame final exigido pela legislação, pelo menos enquanto ela não sofrer alterações. Pois, caso contrário, além de corrermos outros riscos de injustiça, transformaremos os cursos a distância em meros exames certificatórios.

Os riscos de injustiça estão diretamente relacionados com a idéia de exames certificatórios a que nos referimos. Vejamos uma situação hipotética comparando dois alunos. O aluno A participou ativamente do curso, fez todas as atividades com bom desempenho e ele e seus professores sabem que ele aprendeu e atendeu os objetivos propostos, mas no dia do exame final ele, por qualquer razão, está com algum problema físico, por exemplo, enxaqueca. Nessa situação, é bastante provável que ele não tenha um bom desempenho no exame, podendo ser reprovado. Mas o aluno B pouco participou, raras vezes fez 
as atividades propostas e teve um desempenho pífio durante todo o curso faz o exame final e é aprovado. Sem questionarmos outras formas e espaços de aprendizagem que o aluno B possa ter vivido, podemos dizer que o curso a distância que ele fez se resumiu ao exame final que lhe concedeu um certificado. Enquanto o aluno $A$, por uma contingência ficou reprovado e não obteve seu certificado.

Entendemos a importância da certificação em cursos superiores, pois a instituição que o emite está dizendo à sociedade que fulano de tal está apto a exercer determinada profissão ou a realizar determinadas atividades. È a partir da compreensão dessa importância e da responsabilidade da emissão de certificados é que precisamos repensar os sistemas de avaliação sejam elas em cursos presenciais ou a distância.

\title{
Considerações finais
}

Uma avaliação que se coloca a serviço da aprendizagem não pode estar isolada do todo o planejamento educacional, ela deve ser parte integrante do conjunto de ações que objetivam a aprendizagem. Mas como diz Perrenoud ${ }^{90}$ :

\begin{abstract}
nas últimas décadas, não faltaram reformulações de programas e de didáticas. Frequentemente em ruptura com as didáticas tradicionais (e implicitamente com suas formas de avaliação cumulativa, a prova escrita ou oral), as novas didáticas não foram, em geral, muito imaginativas no que concerne à avaliação. Talvez porque, na mente dos reformuladores, a avaliação fica ao Aldo das obrigações, da instituição, da tradição e eles aspiram a "desembaraçar-se delas". Ou porque eles antecipam, como resignação, um "retorno do recalcado", como se as práticas tradicionais de avaliação, tivessem força suficiente para sobreviver a qualquer renovação e para se impor aos professores contra o espírito de toda nova pedagogia.
\end{abstract}

Acrescentamos ao que Perrenoud que as novas tecnologias de comunicação e informação ampliaram as possibilidades e formas de ensinar, mas não o fizeram com a avaliação, pelas mesmas razões apontadas pelo autor.

Existem vários instrumentos de avaliação: observação, provas, relatórios, portfófio, trabalhos de pesquisa, produção de textos, etc. Não existe instrumento mais ou

\footnotetext{
${ }^{90}$ PERRENOUD, P. Avaliação: da excelência à regulação das aprendizagens, entre duas lógicas. Porto Alegre: Artes Médica, 1999.
} 
menos adequado. A escolha de um ou mais instrumentos deve ser referenciado em função dos objetivos ${ }^{91}$ que se deseja atingir. Por exemplo, se um dos objetivos referir-se a memorização de fatos é perfeitamente viável que seja aplicada uma prova de múltipla escolha. Mas se o objetivo estiver relacionado com o saber realizar um procedimento, a prova de múltipla escolha nada nos indicará se o aluno aprendeu. Na realização de procedimentos é imprescindível que sejam realizados na presença física do professor.

No entanto, pensamos que para que aconteçam mudanças na avaliação da aprendizagem, antes de qualquer coisa é necessário que o professor acredite que todos os sujeitos são capazes de aprender.

Entendemos que vários dos princípios estabelecidos acima são pertinentes a avaliação em cursos presenciais, também.

Faz-se necessário explicitar que quando falamos de educação a distância estamos referindo-nos também ao percentual de vinte por cento trabalhados, nessa modalidade, em cursos presenciais. Sendo assim, os mesmos princípios poderiam ser considerados.

Ao estabelecermos um conjunto de princípios temos presente que não são modelos ou regras a serem seguidas. Nosso intuito é de trazer pontos de reflexão que surgiram por meio da nossa atuação profissional para que os envolvidos em trabalhos a distância possam desenvolver práticas educativas que, de fato, objetivem a aprendizagem. Da mesma forma, quando apontamos os problemas encontrados na legislação e identificamos a falta de um projeto nacional de educação, nossa intenção não é de apenas ressaltar as falhas, mas pelo reconhecimento das lacunas, incoerências e equívocos poder estabelecer um diálogo com todos os envolvidos para que possamos melhorar e aprimorar a educação do nosso país.

\footnotetext{
${ }^{91}$ Considerando como "objetivo" não apenas uma lista de conteúdos a serem trabalhados , mas a explicitação de uma intenção, isto é, deve deixar claro que conhecimento, atitude ou habilidade deseja-se que o aluno desenvolva.
} 
Se desejamos a tão falada igualdade social e um papel de destaque positivo nos meios internacionais necessitamos antes de qualquer coisa um projeto nacional de educação que entre outras questões deve:

- Definir o real status que a educação a distância merece, sem retrocessos nem utopias;

- Estabelecer Diretrizes claras para uma educação que liberta e não domestica, portanto trabalhar sob a perspectiva de uma avaliação formativa;

- Fazer valer para o Estado o papel de supervisionar a oferta de cursos de qualidade sejam eles a distância ou presenciais. 


\section{BIBLIOGRAFIA}

AFONSO, Almerindo J. Avaliação Educacional: regulação e emancipação. São Paulo: Cortez Editora, 2000.

ALVES, M. P. e MACHADO, E.A. Avaliação com sentido(s): contributos e questionamentos. Lisboa: De facto, 2008.

ANDRADE, A.A.M. Política e afeto na produção de identidades e instituições: a experiência potiguar. Revista Brasileira de Educação, n. 30, set./out./nov./dez., p. 133 a 181, 2005.

ARETIO, Lorenzo Garcia. La educación a distancia: de La teoria a la prática. Espanha: Editorial Ariel, 2006.

ARETIO, L.G. De la educación a distancia a la educación virtual. Barcelona: Ariel, 2007.

AUSUBEL, D. P.; NOVAK, J. D., HANESIAN, H. Psicología Educativa: un punto de vista cognoscitivo. México: Trillas, 1983.

AVELAR, L. O rádio educativo no Brasil: de Roquette Pinto a Luis Inácio Lula da Silva, Florianópolis, 2004 (trabalho apresentado no II Encontro Nacional da Rede Alfredo de Carvalho - GT História da Mídia Educativa, sob a coordenação de Marlene Blois)

BARLOW, M. Avaliação Escolar: mitos e realidades. Porto Alegre: Artmed, 2006.

BELLONI, Maria Luiza. Educação a distância. Campinas: Autores Associados, 2001.

BOGDAN, R.C.; BIKLEN, S.K. Pesquisa qualitativa em educação. Porto Alegre: Mediação, 1999.

BORBA, M. C. Educação a distância on line. Belo Horizonte: Autêntica, 2008. 
BURKE, P. \& BRIGGS, A. Uma história social da mídia. Rio de Janeiro: Zahar, 2004.

COLL, César. At alli. Os conteúdos da Reforma: Ensino e aprendizagem de conceitos, procedimentos e atitudes. Porto Alegre: Editora Artmed, 2000.

DEPRESBITERIS, Lea. O desafio da avaliação da aprendizagem: dos fundamentos a uma proposta inovadora. São Paulo, EPU, 1989.

CORREA, J. Sociedade da informação, globalização e educação a distância. Rio de Janeiro: SENAC, 2005. Curso de Especialização em Educação a Distância. CDROM.

COSTA, L. V. O professor-tutor e as ferramentas e metodologias de interação no ambiente virtual de aprendizagem e na Web. In SATHLER, L.: AZEVEDO, A.B. Orientação pedagógica em cursos a distância. São Bernardo do Campo, SP: UMESP, 2008.

FRAGALE, Roberto Filho (Org.) Educação a distância: análise dos parâmetros legais e normativos. Rio de Janeiro: DP\&A, 2003.

HADJI, C. Avaliação desmistificada. Porto Alegre: Artmed, 2001.

HADJI, C. A avaliação, regras do jogo: das intenções aos instrumentos. Portugal: Porto Editora, 1994.

HAYDT, Regina Cazaux. Avaliação do Processo Ensino-aprendizagem. São Paulo: Ed. Ática, 1988.

HOFFMANN, Jussara Maria Lerch. Avaliação: mito e desafio: uma perspectiva construtivista. Porto Alegre: Mediação, 2001.

HOFFMANN, J. O jogo do contrário em avaliação. Porto Alegre: Editora Mediação, 2005.

HOFFMAN, Jussara. Avaliação Mediadora: uma prática em construção da préescola à universidade. Educação e Realidade, Porto Alegre, 1993. 
LIMA. G. L. Educação pelos meios de comunicação ou produção coletiva de comunicação, na perspectiva da educomunicação. São Paulo: Gens, 2009.

LITWIN, Edith. Educação a Distância: temas para o debate de uma nova agenda educativa. Porto Alegre: ArtMed, 2001.

LUCKESI, C.C. Avaliação da Aprendizagem Escolar. São Paulo: Ed. Cortez, 2005. $16^{\mathrm{a}} \mathrm{Ed}$.

LUCKESI, Cipriano C. Avaliação de Aprendizagem Escolar. São Paulo: Cortez, 1995.

LUKAS, J. F. e SANTIAGO. K. Evaluación educativa. Madrid: Alianza, 2009.

GATTI, B. A. \& BARRETO, E. de Sá. Professores do Brasil: impasses e desafios, UNESCO - Brasil, 2009.

LÜDKE, M.; ANDRÉ, M.E.D.A. Pesquisa em educação. Porto Alegre: Mediação, 1986.

MARTINS, J. e BICUDO, MARIA A. VIGGIANI A Pesquisa qualitativa em Psicologia: fundamentos e recursos básicos. São Paulo: EDUC, 1989

MIZUKAMI, Maria da Graça Nicoletti. Ensino: as abordagens do processo. São Paulo: Editora Pedagógica e Universitária, 1986.

MOORE, M.; KEARSLEY,G. Educação a distância: uma visão integrada. São Paulo: Thomson Learning, 2007.

PERRENOUD, P. Avaliação: da excelência à regulação das aprendizagens, entre duas lógicas. Porto Alegre: Artes Médica, 1999.

PERRENOUD, P. Construir as competências desde a escola. Porto Alegre: Artmed, 1999b. 
PETERS, Otto. Educação a distância em transição. São Leopoldo: Unisinos, 2004.

PETERS, Otto. Didática do ensino a distância. São Leopoldo: Editora Unisinos, 2003.

RAMAL, A.C. Lendo no viés das palavras: Concepções de avaliação na LDB. Revista da Educação CEAP, ano 6, n. 21, junho, p. 33-47, 1998.

ROSINI, A.M. As novas tecnologias da informação e a educação a distância. São Paulo: Thomson Learning, 2007.

SATHLER, Luciano. A tutoria em cursos superiores a distância. In SATHLER, L.: AZEVEDO, A.B. Orientação pedagógica em cursos a distância. São Bernardo do Campo/São Paulo: UMESP, 2008.

SILVA, Marco (org.) Educação online. São Paulo: Edições Loyola, 2003.

VASCONCELOS, Celso. Avaliação. Concepção Dialéctica - Libertadora do Processo e Avaliação Escolar. São Paulo: Cadernos Pedagógicos do Libertad. 1994.

VASCONCELOS, Celso. Superação da lógica classificatória e excludente da avaliação. Do "É proibido reprovar" ao "é preciso garantir a aprendizagem". São Paulo: Cadernos Pedagógicos do Libertad (5). 1994.

VASCONCELLOS, Celso. Avaliação da Aprendizagem: Práticas de Mudança por uma Praxis Transformadora. São Paulo: Libertad, 2008.

\section{SITES}

O que é

Disponível

em: http://uab.capes.gov.br/index.php?option=com content\&view=article\&id=81\&ltemid= 34, acesso em 28 jan. 2009. 
Histórico

Disponível

em

http://uab.capes.gov.br/index.php?option=com content\&view=article\&id=111\&ltemid $\underline{=27}$, acesso em 28 jan. 2009.

Decreto

Disponível

http://www.etecbrasil.mec.gov.br/gCon/recursos/upload/file/Decreto etec(2).pdf, acesso em 28 jan. 2009.

\section{DOCUMENTOS/ LEGISLAÇÃO}

BRASIL. Ministério da educação. Secretaria de educação a distância. Referenciais de qualidade para cursos de graduação a distância. Brasília, DF, 2002

RIO DE JANEIRO, Se. Curso de Educação a Distância pós-graduação Lato Sensu. Rio de Janeiro, 2005. CD-ROM

BRASIL. Lei $n^{\circ}$ 9.394, de 20 de dezembro de 1996. Estabelece as diretrizes e bases da educação nacional. Disponível em http://www.planalto.gov.br/ccivil_03/LEIS/19394.htm. Acesso em 01 dez. 2009.

BRASIL. Decreto $\mathrm{n}^{\circ} .2494$ de 10 de fevereiro de 1998. Regulamenta o art. 80 da Lei $n^{\circ}$ 9.394, de 20 de dezembro de 1996, e dá outras providências. Disponível em http://www.lei.adv.br/2494-98.htm. Acesso em 30 nov.2009

BRASIL. Decreto $\mathrm{n}^{\circ}$. 5622, de 19 de dezembro de 2005. Regulamenta o art. 80 da Lei no 9.394, de 20 de dezembro de 1996, que estabelece as diretrizes e bases da educação nacional. Disponível em http://www.planalto.gov.br/ccivil 03/ Ato20042006/2005/Decreto/D5622.htm. Acesso em 10 out.2009

BRASIL. Ministério da Educação. Portaria MEC nº 2253 de 18 de dezembro de $2001 . \quad$ Disponivel em http://www.cmconsultoria.com.br/legislacao/portarias/2001/por 20012253 MEC re gulamentacao oferecimento.pdf. Acesso em 12 set.2009

BRASIL. Ministério da Educação. Portaria MEC nº 301 de 7 de abril de 1998. Disponível em http://portal.mec.gov.br/seed/arquivos/pdf/tvescola/leis/port301.pdf. Acesso em 01 dez. 2009. 
BRASIL. Ministério da Educação. Portaria MEC n. 4.059, de 10 de dezembro 2004. Disponível em http://portal.mec.gov.br/sesu/arquivos/pdf/nova/acs portaria4059.pdf Acesso em 01 dez. 2009. 


\begin{abstract}
ANEXOS
Os anexos abaixo relacionados encontram-se reunidos no CD-ROM que integra esta tese como encarte.
\end{abstract}

- Lei $\mathrm{n}^{\circ}$ 9394, de 20 de dezembro de 1996. - Lei de Diretrizes e Bases

- Decreto $n^{\circ} 2494$, de 10 de fevereiro de 1998.

- Decreto $n^{\circ}$ 5622, de 19 de dezembro de 2005.

- Portaria MEC n 301, de 7 de abril de 1998.

- Portaria MEC n²253, de 18 de dezembro de 2001.

- Portaria MEC n 4059, de 10 de dezembro de 2004.

- Resolução CNE/CP 01/2002.

- Parecer CNE/CES 492/2001

- Resolução CNE/CP 9/2001

- Referenciais de qualidade para cursos de graduação a distância.

- Projeto da Universidade Federal de Santa Maria

- Projeto da Universidade Federal de Santa Catarina

- Orientação Didático-Pedagógica em cursos a distância - Universidade Metodista 